\title{
An In-Depth Analysis of Physical Blue and Green Water Scarcity in Agriculture in Terms of Causes and Events and Perceived Amenability to Economic Interpretation
}

\author{
Kalomoira Zisopoulou ${ }^{1}$ and Dionysia Panagoulia ${ }^{2, *}$ \\ 1 Travaux Publics, Becket House, London SE1 7EU, UK; kal.evg.zisopoulou@gmail.com \\ 2 Department of Water Resources and Environmental Engineering, School of Civil Engineering, \\ National Technical University of Athens, Zografou, 15780 Athens, Greece \\ * Correspondence: dpanag@hydro.ntua.gr
}

Citation: Zisopoulou, K.; Panagoulia, D. An In-Depth Analysis of Physical Blue and Green Water Scarcity in Agriculture in Terms of Causes and Events and Perceived Amenability to Economic Interpretation. Water 2021, 13, 1693. https://doi.org/10.3390/ w13121693

Academic Editor: Luis Garrote

Received: 21 May 2021

Accepted: 4 June 2021

Published: 18 June 2021

Publisher's Note: MDPI stays neutral with regard to jurisdictional claims in published maps and institutional affiliations.

Copyright: () 2021 by the authors. Licensee MDPI, Basel, Switzerland. This article is an open access article distributed under the terms and conditions of the Creative Commons Attribution (CC BY) license (https:// creativecommons.org/licenses/by/ $4.0 /)$.

\begin{abstract}
An analytical review of physical blue and green water scarcity in terms of agricultural use, and its amenability to economic interpretation, is presented, employing more than 600 references. The main definitions and classifications involved and information about reserves and resources are critically analyzed, blue and green water scarcity are examined along with their interchange, while their causal connection with climate in general is analyzed along with the particular instances of Europe, Africa, Asia and the WANA region. The role of teleconnections and evaporation/moisture import-export is examined as forms of action at a distance. The human intervention scarcity driver is examined extensively in terms of land use land cover change (LULCC), as well as population increase. The discussion deals with following critical problems: green and blue water availability, inadequate accessibility, blue water loss, unevenly distributed precipitation, climate uncertainty and country level over global level precedence. The conclusion singles out, among others, problems emerging from the inter-relationship of physical variables and the difficulty to translate them into economic instrumental variables, as well as the lack of imbedding uncertainty in the underlying physical theory due to the fact that country level measurements are not methodically assumed to be the basic building block of regional and global water scarcity.
\end{abstract}

Keywords: blue water; green water; scarcity; climate; water availability; inadequate water accessibility; climate uncertainty; land use land cover change; population

\section{Introduction}

Water, an economic good [1,2] and "total social fact" [3], is a critical resource [4] as it is a component of human life and ecosystem support and it lies at the base of Maslow's pyramid of human needs [5], while quantitatively/qualitatively is one of the three components of water security [6]. The water scarcity case, expressed in terms of water supply crises, is the number one global societal risk in terms of impact, even greater that the spreading of infectious diseases, and is expected to grow by $43 \%$ in 2025 according to the 2015 World Economic Forum [7]. In addition, it will impact $>56.2 \%$ of the global population by 2080 [8] in terms of societal risks, with both high impact and high likelihood, as seen in Figure 1.

Water scarcity is considered to be the result of a complex interaction of social, economic, and environmental factors, and is seldom caused solely by a lack of precipitation [9]; people may be moved to water resources [10,11] (case studies in [12]) or water resources may be moved to people as, e.g., in the economic development of the Western USA [13] or by reinforcing green water by allowing water surplus to infiltrate into the root zone [14]. Added to these, water consumption is dependent on population growth [14] and climate change $[15,16]$, which intensify scarcity, shocks, and access inequalities and induce physical, financial, regulatory, and reputational risks to businesses [9]. At the same time, water distribution does not match population concentrations, groundwater supplies are dwindling, 
and the water multiplier effect [17] does not work in underdeveloped countries, which have no extensive recycling facilities, if at all.
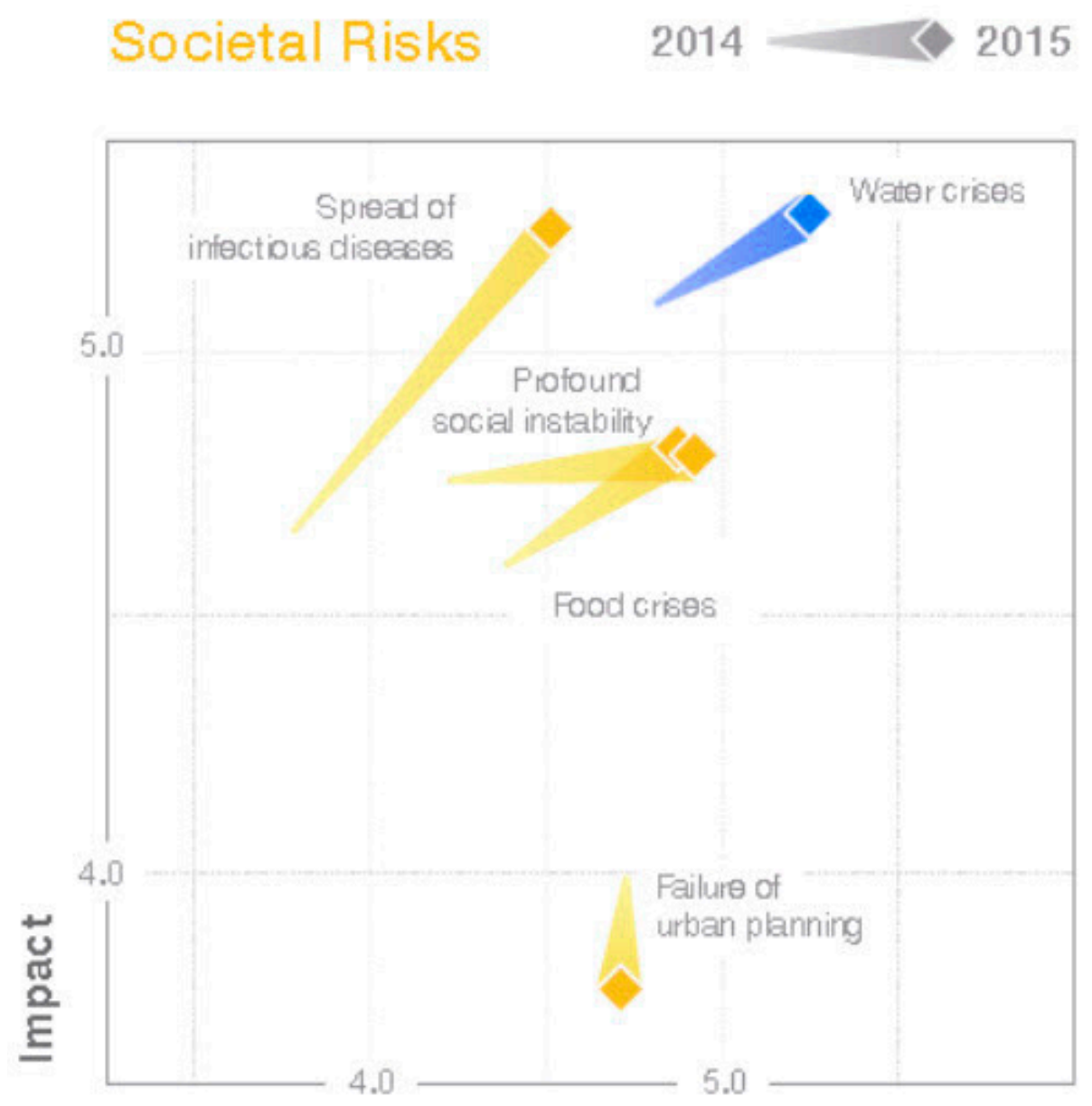

\section{Likelihood}

Figure 1. Impact-Likelihood diagram of water crises (modified from [7]).

Alternatively, the demand and supply [18] aspect of overpopulation [19], agriculture [20], pollution of water [21], and improper government policies [22], the last of which potentially leading to a case of the "Green Paradox" [23], are important reasons for water scarcity, while land use and land cover change, encompassing crops, livestock, fisheries, aquaculture and forestry, are causes and a victims of water scarcity $[16,24,25]$. The Comprehensive Assessment of Water Management in Agriculture which is influenced by demand and supply in [18], concludes that water scarcity is a major global constraint to agriculture [26] as well as a growing risk to business and investors [27].

There are two types of water scarcity: physical scarcity and economic scarcity [18]. Physical scarcity is said to occur when water cannot satisfy all demands (including environmental flows) [28], either despite or because of the fact that the global system is interconnected hydro-climatically [29]. Economic scarcity is described as a situation where the socio-economic system is unable to utilize existing water in order to satisfy all demands [30], lacking, in essence, the infrastructure development that consists of storage and timely distribution and access [31], alternatively if human, institutional and financial capital limit access to water [32,33]. Physical and economic scarcity are shown in Figure 2. 


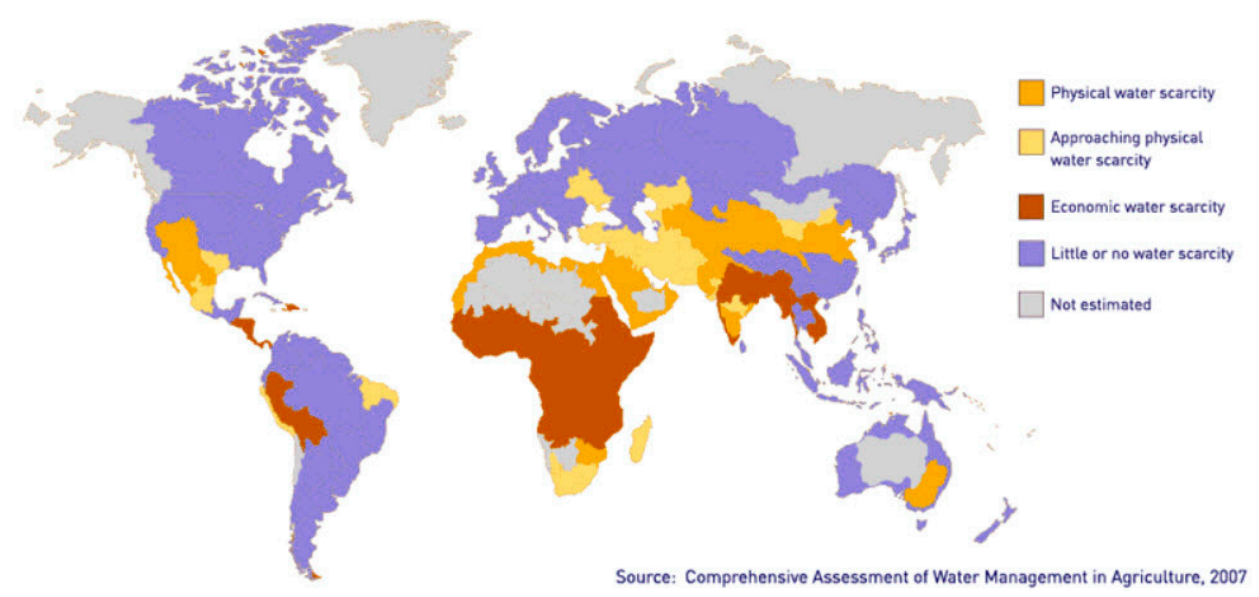

Figure 2. Global map of regions with Physical or Economic scarcity (modified from [34]).

Physical water scarcity, the major global management problem of the 21st century [35], causes, among other problems, environmental degradation [36], a decline in groundwater (including subsurface water occurring beneath the water table in soils and geologic formations that are fully saturated [37,38]), and inequitable water distribution [39]. Imposing blue water limitations for agriculture and relying increasingly on rain fed green water has consequences, e.g., these limitations, if imposed on the Western U.S., China and West, South, and Central Asia, would shift 20-60 Mha of cropland to rainfed agriculture, at a loss of 600-2900 Pcal in food production, by the end of this century [40].

Socio-economic drought definitions associate the supply and demand of some economic goods with elements of meteorological, hydrological, and agricultural drought, which occurs when the demand for an economic good exceeds supply as a result of a weather-related shortfall in the water supply [41]. Water scarcity is measured by a variety of indicators/metrics, reviewed in [42,43], which are quantified in [26] and criticized in [44]. Of these, the indicator of the blue water sustainability index (BIWSI) [45] is of particular interest as, beyond consumptive blue water use (CBWU), it includes non-renewable groundwater abstraction $\left(\mathrm{NRGW}_{\mathrm{A}}\right)$ and non-satisfied environmental streamflow.

The purpose of this analytical review is to establish a platform of physical blue and green water scarcity characteristics with respect to agriculture, classified according to their causes and impact by employing concrete examples indicative of the characteristic's spatio-temporal spectrum, which are useful in analyzing the economics of water scarcity for blue and green water, focusing on agriculture. Section 3.1 describes the variety of existing pertinent definitions and classifications; Section 3.2 analyzes blue and green water scarcity; Section 3.2. examines blue and green water interactions with climate, including short analyses of Europe, Africa, Asia, and the WANA region.; Section 3.4 addresses the subject of green and blue water impact by actions at a distance, teleconnections and evaporation and moisture import/export. Section 3.5 Discusses important points regarding the problems encountered.

\section{Methodology}

The objective of this paper is to present blue and green water scarcity, both in general case and examples in terms such that a manifest relation can be established between definitions and aspects of the physical causes and impacts of scarcity with respect to agriculture on the one hand, and instrumental economic variables that may lead to economic results and models on the other. In Figure 3, a simplified process of a country level physical event is presented, where the main sequence is global climate to local climate to scarcity event, and in the end to water stakeholders. As intermediaries between global and local climate are climate teleconnections, evaporation moisture import-export, which is in bidirectional feedback mode, and direct intervention; between the scarcity event and water stakeholders are physical and economic scarcity processes. One of the contributors, human intervention, 
is broken into two parts, global and local, connected by bidirectional feedback. The curved arrows show the connections this paper aims to facilitate.

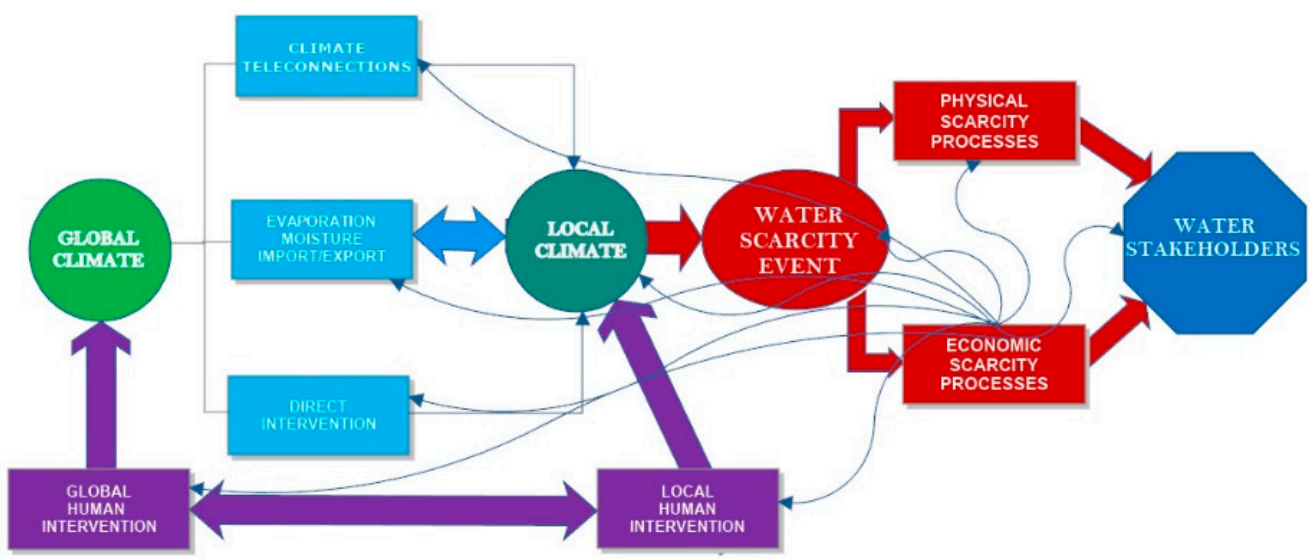

Figure 3. A simplified process of country level water scarcity event.

Despite the simplicity of the diagram, it is easy to see that the causes and effects of physical water scarcity form in effect a multifaceted construct, where localized country physical conditions may lead to either similar or different results for the same physical phenomenon, hence the large number of references.

The stages shown below expose as many of the multiple aspects of this scarcity as possible and their causal interconnections with widely acceptable mainline physical results using concrete events described in the relevant literature. The use of these events also serves the purpose of opening an avenue that serves researcher who wishes to assess and evaluate, in economic terms, the class of events to which a particular event belongs.

The first column in Figure 4 refers to the general case of physical phenomena judged to be pertinent on the basis of normative decision and its row expansions refer to particular influential phenomena while their content includes special cases.
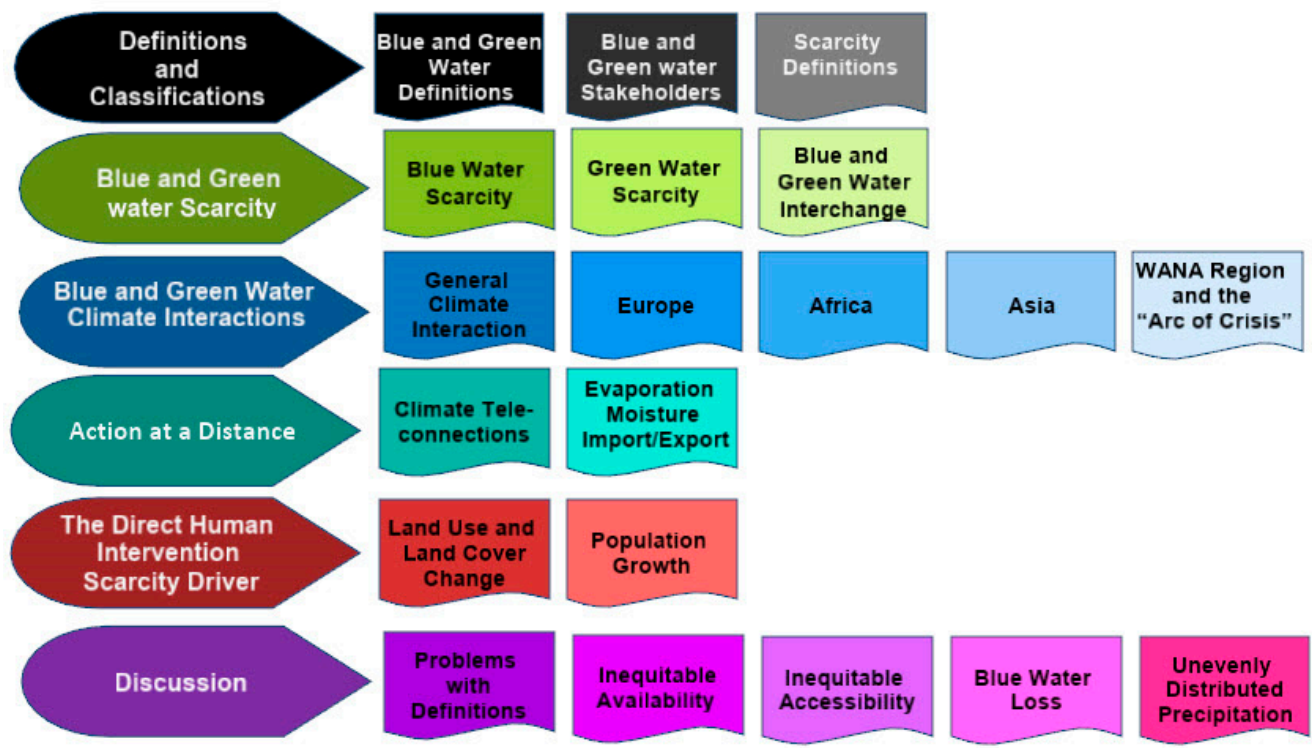

Figure 4. The stages of Methodology. 


\section{Results}

\subsection{Definitions and Classifications}

\subsubsection{Blue and Green Water Definitions}

A variety of definitions for both blue and green water exist [46]. Falkemark's original definition was that incoming rainfall is partitioned into vertical upward flow and horizontal flow, leading to aquifers and rivers, which constitutes "blue water" while "green water" is the water in the root zone, the part of the upper vadose zone instrumental in partitioning rain and irrigation water into evaporation, transpiration, runoff, and deep drainage [47], which is the source of plant nutrition [48]. A later, more precise definition [49], was given in terms of resource supply: blue water is the water in aquifers, lakes, and dams, and green water is the moisture in the soil which are related to the liquid blue water flowing through rivers and aquifers and the green water vapor flowing back to the atmosphere. Green water is divided into two parts [49-51], one part is stored in the soil as moisture and another part is in motion via the evapotranspiration process.

Blue water can be classified according to its state: in liquid flow form, stocked as runoff, rivers, reservoirs, wetlands, lakes, snowpack, aquifers for the consumptive pathway of household or industrial uses, drinking water and product integration, and in vapour flow form, stocked as surface water or groundwater for the consumptive pathway of evapotranspiration from irrigation [49,52]. Green water can be classified in the same way: in vapour flow, as productive green water is stocked as soil moisture for the consumptive pathway of plant transpiration, and in vapour flow as unproductive green water stocked as soil moisture and intercepted rainfall for the consumptive pathway of evaporation (soil, surface, snow) [49,52].

\subsubsection{Blue Water Stakeholders}

Water use, referring usually to blue water, is defined as its removal from its source and is distinguished into "withdrawal" where water returns to the water system by return flows or leakage, and as "consumption" [53], termed as "irretrievable or irrecoverable loss" [54] to signify that it may be transformed to a form not immediately returnable to its initial state, measuring the amount that is removed from rivers, lakes, or groundwater sources and evaporated to the atmosphere [55,56]. In [57], withdrawals and consumption are considered to be the maximum and minimum levels of scarcity. For the case of agriculture, water use may be defined to be the quantity of water which is in the process of evapotranspiration [58], two-thirds of which are supplied by plant transpiration $[59,60]$ re-enforcing the role of green water. It should be noted that one of the end results of evapotranspiration, net precipitation on land $\left(40,700 \mathrm{~km}^{3} /\right.$ year), suffers a great deal of waste: $50 \%$ becomes floods and $20 \%$ is in areas that are too remote to be of immediate use [61].

According to the Organization for Economic Co-operation and Development (OECD) [62], in the case of water, "Stakeholders are herein defined as persons or groups who are directly or indirectly affected by water policy, as well as those who may have interests in it and/or the ability to influence its outcome, either positively or negatively" which includes " businesses depending on water for their process, those profiting from the water chain and those selling water dependent products" [62]. This is very close to Freeman's stakeholder definition of corporate stakeholder being "any group or individual who can affect, or is affected by, the achievement of a corporation's purpose" which includes employees, stockholders and customers [63] (p. vi, EXHIBIT 1.5 p. 25) and, most importantly, allows the OECD definition to be separated into immediate or primary and secondary stakeholders extending the secondary "potential users" by Newcombe [64] in terms of Freeman's definition to actual secondary stakeholders, seen also in [65] and in a similar way to a modernized version of [66] (p. 941, Table 1).

In Figure 5 the circular stakeholder diagram found in [54] is broken down into levels of impact, according to the nature of the stakeholders, from primary to tertiary, distributed according to normative decision. The immediate (primary) stakeholders are seen to be 
agriculture, industry, and municipal water provision (which include household uses), while the whole population is a tertiary stakeholder.

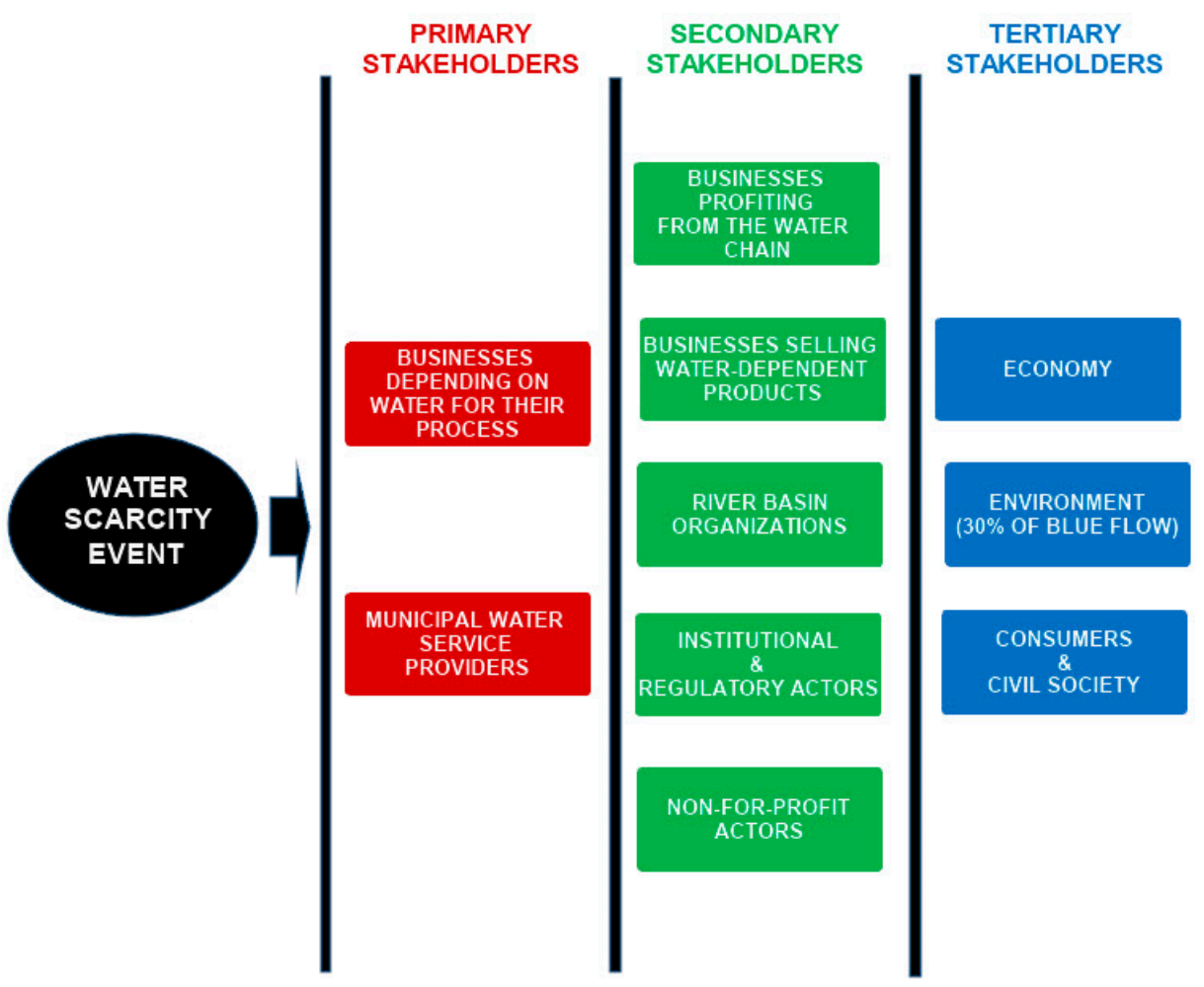

Figure 5. Major stakeholders (modified from [62]).

In Figure 6, agriculture is seen to be the dominant stakeholder due to the continuous pressure exerted by the increase in population and total consumption of food and the corresponding increase in land use land cover change.

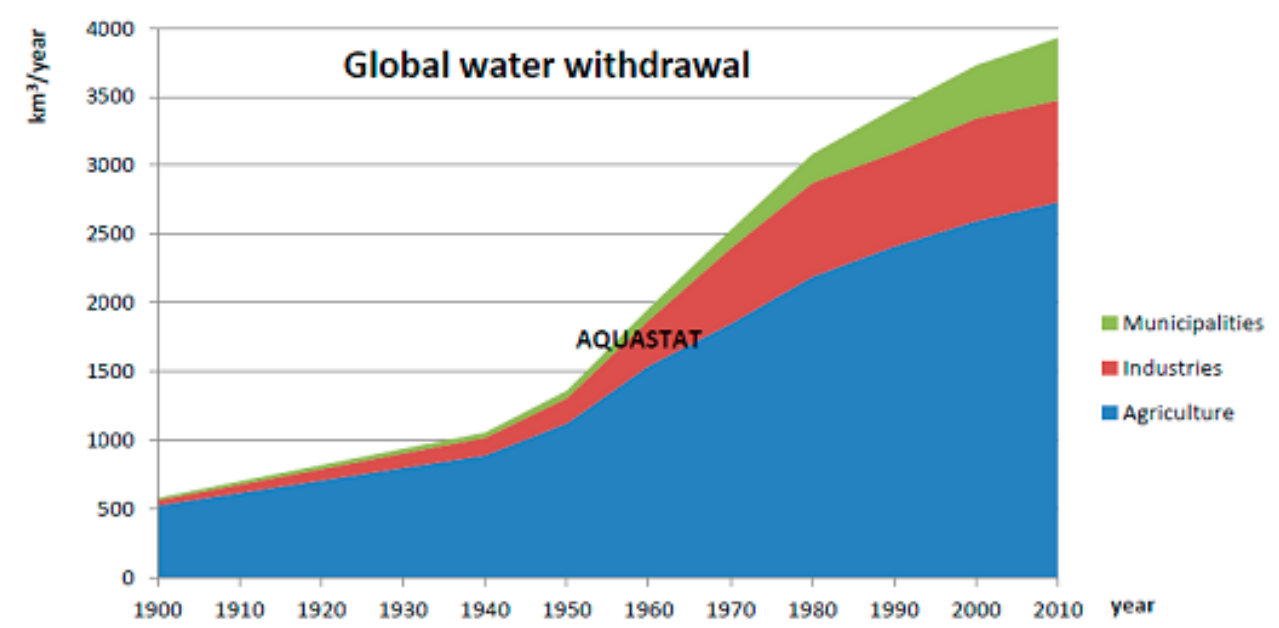

Figure 6. Global water withdrawal 1900-2010 (modified from [67]).

Withdrawal division by continent for primary stakeholders in Figure 7 shows disparate distribution for agriculture. This is due to population increases in Asia and Africa, which are not commensurate with those in Europe or the USA and Canada population component in the Americas. In addition, the fact that inferior technology is employed in Africa, leading to low yields per ha, should be taken into consideration. 


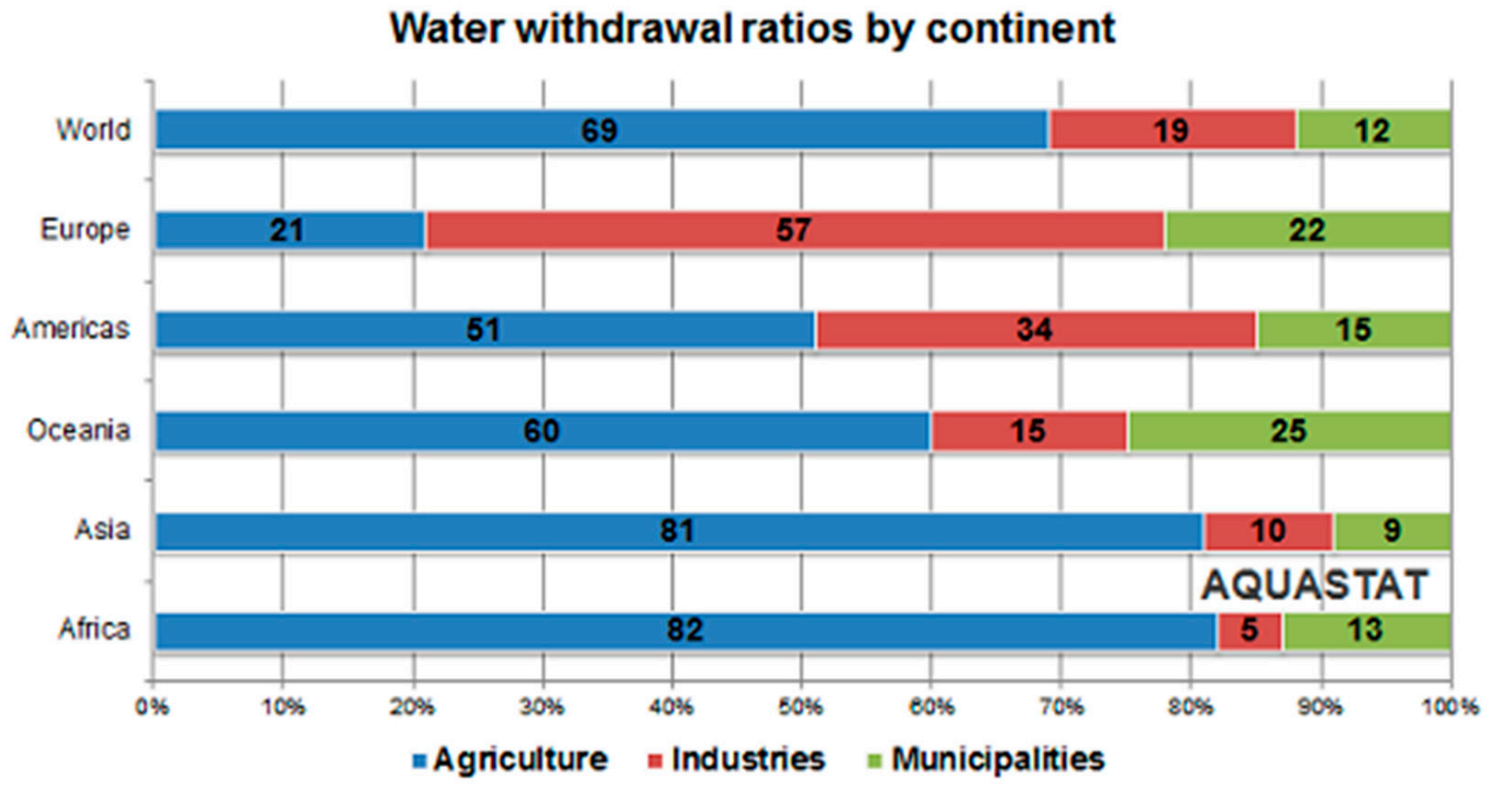

Figure 7. Water Withdrawal ratios by continent (modified from [67]).

Water withdrawal by country economic grouping (OECD, BRICS (Brazil, Russia, India, China and South Africa), ROW (Rest of the World)) are as below in Figure 8 and the differences between the OECD and the other two groups can be ascribed to the fact that BRICS' economic growth is sought in a more pressing and less rule-bound way than in OECD countries.

Freshwater use by aggregated region, 1901 to 2010

Global freshwater withdrawals for agricultural, industrial and domestic uses by aggregated regional groupings. OECD members are defined as countries who were members in 2010 and their membership was carried back in time. BRICS countries are Brazil, Russia, India, China and South Africa. ROW refers to the Rest of the World, excluding OECD and BRICS countries.

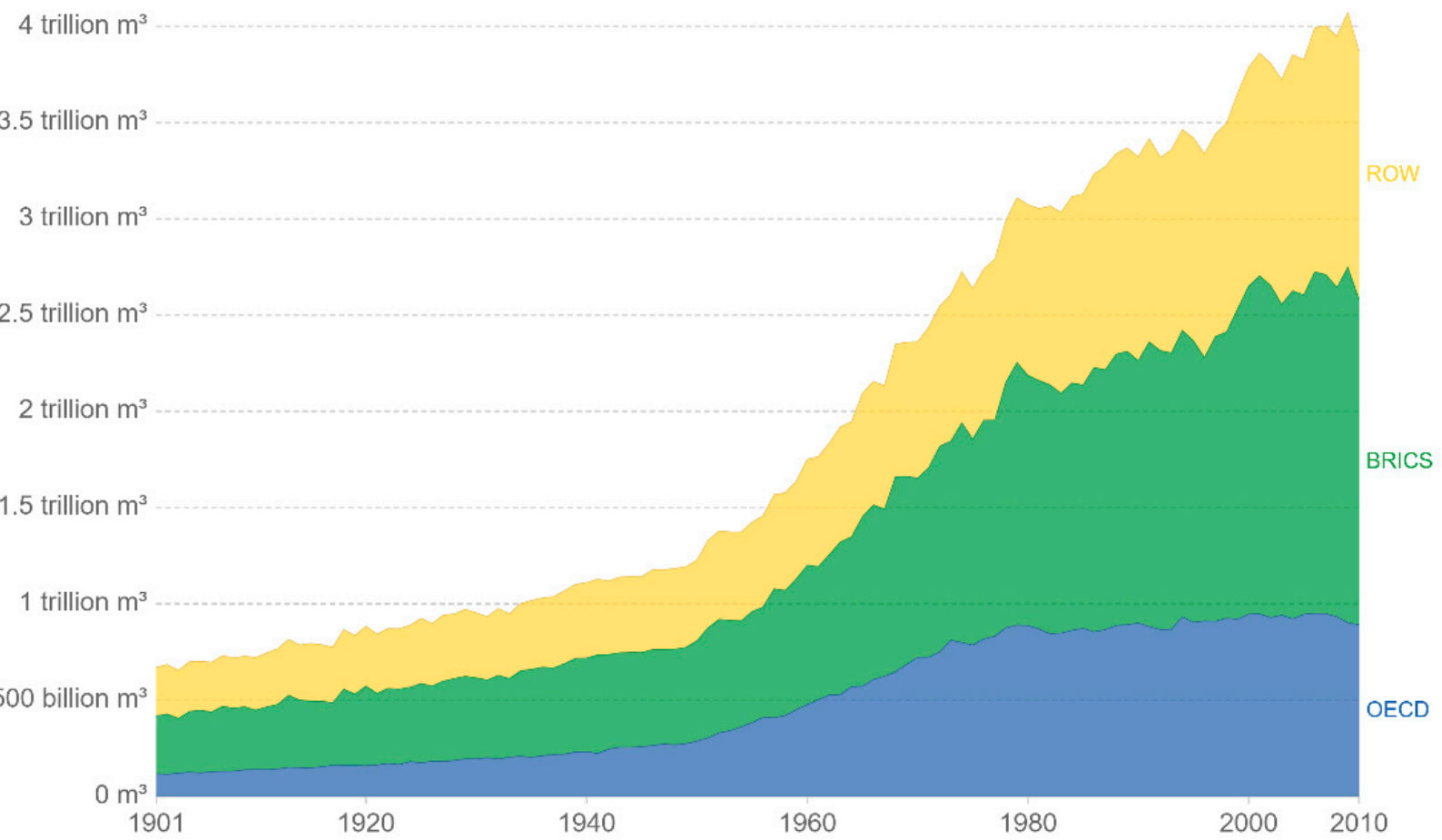

Figure 8. Water withdrawals by country economic grouping (modified from [68]). 


\subsubsection{Scarcity Definitions}

Scarcity is an acceptable property of water as it is an irreplaceable input to goods that satisfy economic wants [69] and is, by its nature, a finite resource and essential good according to the Dublin Water First Principle "Water is a finite, vulnerable and essential resource which should be managed in an integrated manner" [1]. An initial institutional definition of water scarcity was given by Winpenny as "In popular usage, "scarcity" is a situation where there is insufficient water to satisfy normal requirements. However, this common-sense definition is of little use to policy-makers and planners. There are degrees of scarcity: absolute, life-threatening, seasonal, temporary, cyclical, etc. Populations with normally high levels of consumption may experience temporary scarcity more keenly than other societies accustomed to using much less water. Scarcity often arises because of socio-economic trends having little to do with basic needs. Defining scarcity for policymaking purposes is very difficult." [70] in FAO [71]. Using this as a basis, the 2007 U.N. definition, which stresses the relative nature of water scarcity, followed "The point at which the aggregate impact of all users impinges on the supply or quality of water under prevailing institutional arrangements to the extent that the demand by all sectors, including the environment, cannot be satisfied fully [...], a relative concept [that] can occur at any level of supply or demand. Scarcity may be a social construct (a product of affluence, expectations and customary behaviour) or the consequence of altered supply patterns stemming from climate change. Scarcity has various causes, most of which are capable of being remedied or alleviated." [72]. The exception to alleviation is defined by "absolute water scarcity" which is "wor to satisfy total demand after all feasible options to enhance supply and manage demand have been implemented" [73] usually set to less than $<500 \mathrm{~m}^{3}$ per capita of renewable water [74]. In addition, "chronic water shortage" exists when renewable water resources per capita are in the region 500-1000 $\mathrm{m}^{3}$ and "regular water stress" in the region between $1000-1700 \mathrm{~m}^{3}$ per capita [74]. It should be pointed out that the environmental flow requirement is predetermined as a mandatory $30 \%$ of the available sum of blue and green water [75] which reduces availability. However, water scarcity is claimed to be a "governance crisis, not a [water] resource crisis" [76].

Falkenmark distinguishes four modes of water scarcity [77]:

A. Short-term growing season aridity

B. Recurrent drought year intermittent droughts

C. Soil degradation-induced landscape desiccation (man-made draught)

D. Water stress induced by an exorbitant population number per unit of water cycle available.

According to the EU, water scarcity is interpreted as the case where "water demand exceeds the water resources exploitable under sustainable conditions" [78]

In modern settings, water scarcity may be defined in general as in [41]:

a. an imbalance of supply and demand under prevailing institutional arrangements and/or prices $[79,80]$

b. an excess of demand over available supply [81]

c. a high rate of utilization compared to available supply, especially if the remaining supply potentials are difficult or costly to tap [82].

Simpler definitions are the case of where water resource availability is less hence the means of water availability and accessibility to the concerned population become restrained [83], when available resources are insufficient to meet the sum of total demand and minimum environmental flow [84] or the one where water is scarce for any reason [55].

Another definition of scarcity is based on the imbalance between supply and demand created by intra-annual and inter-annual fluxes which are manifested due to lack of freshwater natural or constructed storage, a fact that makes inadequate storage, i.e., storage scarcity, an equivalent definition to the classical definitions of water scarcity as it is operationally equal in terms of volume, location and timing to the supply-demand difference $[85,86]$. The theory stresses the point that all calculations should be based on physical parameter 
quantification of supply and demand, and that, based on these results, decision making regarding additional storage should be a result of synergy between national and local authorities. Insufficient water storage exists in Canada (694 MAF), THE U.S.A. (1420 MAF), China (2280 MAF), India (245 MAF), and Pakistan (13.20 MAF) [87].

\subsection{Blue and Green Water Scarcity}

Water used in agriculture amounts to 70\% of withdrawals [88] and $92 \%$ of global fresh water consumption [89] which occupies $40 \%$ of total available land divided into $1 / 3$ for crop cultivation and $2 / 3$ for livestock grazing [90]. The average annual blue water consumption is $1000-1700 \mathrm{~km}^{3}$ /year [91] while annual green water consumption on rainfed and irrigated cropland is in the order of $5000 \mathrm{~km}^{3} /$ year; to this should be added around $20,000 \mathrm{~km}^{3}$ /year for perceived to be managed grassland/grazing land and around $49,000-56,500 \mathrm{~km}^{3} /$ year for the support of non-agricultural ecosystems [52]. Irrigated agriculture (blue water) amounts to $20 \%$ of total cultivated land but yields $40 \%$ of total global produce [92], but $60 \%$ of total cultivated land is rainfed [55]. In year 2000 global cropland was $15 \times 10^{3} \mathrm{~km}^{2}$ and pasture area was $34 \times 10^{3} \mathrm{~km}^{2}$ [93]; while agricultural land was $46.8 \times 10^{3} \mathrm{~km}^{2}$ in $1992,36.763 \%$ of total land, and $48.6 \times 10^{3} \mathrm{~km}^{2}$ in $2015,38.177 \%$ of total land, an increase of less than $2 \%$ [94].

In general, virtual water, commodities, usually water moved in international trade in cereals $[95,96]$, which by a wide interpretation of the Heckscher-Ohlin model are, in reality bundles of factors [97], including a sizeable amount of water, is exported by countries which do not suffer from either blue or green water scarcity, however, despite the fact that exports are mainly rainfed, there is a substantial increase in associated irrigation water expenditure, which beyond creating a depletion $[98,99]$, is estimated to be a global increase of $17 \%$ in a 25 -year period [100]. It is quantified as an "irretrievable or irrecoverable loss" in the sense of [59] for the exporting country and it should be taken into consideration that scarce water may be exported via virtual water trade, despite the fact that this increases scarcity at the exporting country [101].

\subsubsection{Blue Water Scarcity}

In the case of blue water, of which availability depends on climate (precipitation, temperature, radiation) and its variability, river flow directions, and the spatio-temporal distribution of lakes and reservoirs [102], upstream water consumption scarcity is attributed to shortage, the low availability of water per capita i.e., population driven scarcity. Stress is defined as high water use relative to water availability $[103,104]$ as in the projected reduction of river inflows in the Tonle Sap Lake Basin, Cambodia [105], reductions in flow because of increasing temperatures in the upper Colorado River basin (UCRB) [106], multi-model global assessment [107], regional impact in Tangshan city, Hebei Province, China [108] and on the EU drinking water [109]. Blue water scarcity may be due to the competition over limited runoff and is usually measured as the ratio of blue water use to available blue water [43], a restrictive variant of the Water Resources Vulnerability Index [110], or the ratio of blue water use footprint to available blue water footprint [111]. According to Falkenmark, blue water shortage occurs on the basis of the number of people competing for a limited water resources, a Malthusian view based on a limited resource divided among an ever growing population, in which case "water crowding" is high when per capita water availability is less than the "principal water requirements" of $1700 \mathrm{~m}^{3} \mathrm{cap}^{-1} \mathrm{yr}^{-1}$ [112] while below $1000 \mathrm{~m}^{3}$ cap $^{-1} \mathrm{yr}^{-1}$ chronic water shortage could occur under certain conditions which may "be the single greatest and most urgent development constraint" [113] impacting 2.3 bn people [104]. In addition, South and Southeast Asia, under pressure of increasing agricultural production, have increased blue water withdrawals amounting to $>60 \%$ of agricultural water use [114].

According to the planetary boundaries theory [115-120], where green water has not as of yet been incorporated [121], each main control variable is divided quantitatively at a global level into a safe operating space and a dangerously uncertain one 
regarding withdrawals of any kind. While blue water available resources amount to $12,500-15,000 \mathrm{~km}^{3}$ year $^{-1}[122,123]$, in total, the water withdrawal control variable has a safe operating space of $4000 \mathrm{~km}^{3}$ year ${ }^{-1}$, which, including a region of uncertainty, reaches to $6000 \mathrm{~km}^{3}$ year $^{-1}$ [115]. In the case of blue water withdrawal as $\%$ of mean monthly river flow the total operating space, where the low bound is the safe part, is for low-flow months $25-55 \%$, for intermediate flow months $30-60 \%$ and for high-flow months $55-85 \%$ [124]. It should be mentioned that water influences decisively all the basic control variables of this theory [125], hence global limitations on water may impose on the rest of the main control variables unnatural constraints and that in regional cases the limits imposed may be exceeded due to justified necessity [126].

Atmospheric evaporation recycling within drainage basins can reduce blue water consumption volumes by up to $32 \%$ [127]. A multi-dimensional diagnosis model (MDDM) assesses blue water at a regional level so that scarcity can be detected [128] and a review of the methodological challenges remaining for this assessment via footprint is in [129]. It may be that shifts toward highly resource-efficient cropping lead to increased demands of blue water if they are dependent on irrigation as is the case in China's Huang-Huai-Hai region [130], a manifestation of the Green Paradox [23].

In [131], the five elements of terrestrial water storage (TWS), among which are the constituents of blue water, groundwater and surface waters, are shown to be range bounded dynamic quantities trending below past ranges, in particular where groundwater is being withdrawn at an unsustainable rate while groundwater stress levels are defined and quantified using GRACE in [132].

\subsubsection{Green Water Scarcity}

Green water has three functions: regulatory (soil moisture, evaporation and transpiration flows which regulate via carbon sequestration and water as a component of greenhouse gas the planetary energy balance and climate system), productive (food, biomass and bioenergy production sustaining evapotranspiration) and overland water cycle regulation via moisture feedback evaporation [133]. It should be noted that green water flow is comprised of $59 \%$ transpiration, $21 \%$ plant interception, $10 \%$ floor interception, and $6 \%$ soil moisture evaporation [134], of whose partly contrasting roles are analysed in [135]. Green water is replenished by land precipitation or capillary rise from groundwater lying blow its zone [136]. Extreme precipitation redistributes its land impact by reducing the resultant green water and increasing soil erosion in comparison to regular precipitation [137]. Green water scarcity, measured by its fluxes as being approximated by its actual evapotranspiration [45], which is important in problematic regions e.g., $>95 \%$ of sub-Saharan Africa is rainfed [114], where green water availability depends on agricultural area and its expansion [138], climate, in terms of rainwater partitioning, as in climate change effects on groundwater recharge [139], in recent advances in groundwater and climate change [140], in changes in mean and extreme precipitation in general [141] and over India [142] and Africa $[143,144]$, in projected climate change for groundwater recharge in the Western United States [145], crop type as in the relationship of water scarcity with food production [102], is defined indirectly via the fraction of irrigation water required over crop water intake, a form of "green water deficit" [146], while alternative scarcity indicators are defined in [147], and the existence of scarcity is justified as there is a limit to green water resources in [148], where a supplement [149] is included, depicting numerical results for all countries. Assessment methods are e.g., in a case study in the Hai River Basin, China [150], by partitioning evapotranspiration into green and blue water sources [151], using GABI [152] and others. Green water scarcity, by calculating green water scarcity characterisation factors (CFs), occurs in Portugal and will get worse during the period 2046 to 2065 [153], the rapid development of urbanization may cause serious shortage of both blue and green water resources as is the case in rapidly-developing Xiangjiang River Basin in China [154]. Green water scarcity is induced in higher altimetry vegetation during a 
temperature rise in lower altitudes as evapotranspiration in large areas over the Alps was above average despite low rainfall [155].

\subsubsection{Blue and Green Water Interchange}

Although blue and green water definitions might imply some form of definition-wise physical non-intersection between them i.e., the fact that that there is a flow path distinction and a location distinction [55], there exists physical interchange interaction between blue and green water in the ground where blue water moves downward into the ground according to the Dahl hierarchy (sediment scale $(<1 \mathrm{~m})$, reach scale $(1-1000 \mathrm{~m})$ and catchment scale $(>1000 \mathrm{~m})$ ) [156], a form of percolation ending either in phreatic zone groundwater pockets, also seen in shallow unconfined aquifers [157], or flowing to create blue water flows [158], although, depending on the existence of semi-aridity conditions, there is transient resistivity to downward interaction as in the $200 \mathrm{~km}^{2}$ Wailepalle watershed in the high Deccan plateau in India [159]. This interaction extends to the fact that terrestrial precipitation, which includes the blue water renewability package, has $65 \%$ of its source in terrestrial evaporation flows to the atmosphere [160], whose soil moisture component, like interception [161], is ephemeral (as seen in a simple model of the Budyko curve [162]). Additionally, there is interaction between blue and green water in terms of trade-offs, as seen in the Amazon [163] and via green-blue water accounting in soil water balance in [164]. Interlinkages also exist in the case of an arid endorheic river basin where hydrological cycling is heavily altered by human activities as is the case of an arid catchment in Northwest China [165]. Hence, they are not contiguously distinct either in situ or in composition, which poses a problem in measuring the two quantities unless the bilateral transference is explicitly assessed quantitatively.

\subsection{Blue and Green Water Climate Interactions}

\subsubsection{General Climate Interaction}

Climate, which is subject to global short term [166] and long term [167] changes [168] and variability (which can assessed on a millennial-scale, spanning 800,000 years and its influence on climate change [169] is due to the alteration of a large number of conditions) is depicted using the Köppen-Geiger classification [170]. The consequences are far ranging e.g., climate influences cleaner production [171].

Climate change is a statistically determinable change in the state of the climate which has a long-term duration due to natural (internal or natural variability)/anthropogenic causes [172]; climate variability, on the other hand, is the occurrence of annual distancing of main parameters from the long term mean as seen in Figure 3. At the global scale, in global climate models (GCMs), anthropogenically induced change overcomes internal variability at the decadal time scale [173] but, at regional and local scales they tend to be equally important, even during 50-year periods [174]. Natural variability, which at the regional level is distinguishable from anthropogenic forcing regarding precipitation [175], may be used in the detection of anthropogenic climate change as a cause or both regional and local precipitation [176] and in the case of Pakistan using the 1951-2015 APHRODITE dataset, a quantitative estimate of induced climate change variation in precipitation was deduced [177]. Climate models suffer from structural model uncertainty and parameter uncertainty [178]. As a general rule in ensemble forecasting (ensemble prediction systems (EPS)) [179], where ensemble spread is considered to be a proxy for prediction uncertainty, reliable predictions are described by the case where the time-mean ensemble spread about the ensemble-mean prediction equals the time-mean RMSE of the ensemble-mean forecast [180]. Hence, the more the forecasting systems used the less the resulting uncertainty, as in seasonal forecasting using the DEMETER data set [181], in flood forecasting using the TIGGE system [182] and the encouraging results shown in precipitation at sub-monthly time scales in [183]. Predictions at global and regional scale vary, as in [184], globally at 1.75 (1.65-1.85) ${ }^{\circ} \mathrm{C}$ increase over preindustrial temperature e.g., it is expected to have a global increase of heatwave frequency chance by $73(67.2-77.9) \%$ compared to $33 \%$ in the 
1981-2010 period, global hydrological drought frequency chance will have an increase by $8.3(6.1-9.9) \%$ compared to $6.1 \%$ in the same period while global agricultural drought (SPEI) frequency chance will reach $23.6(16.1-29.5) \%$ compared to $9.4 \%$ in the same period. As global mean temperature increases to $4{ }^{\circ} \mathrm{C}$, all positive or negative climate impacts become worse, while, at a continental level, these predictions vary. Regional climate models (RCMs) depend on global models by "regionalization" as in the review in [185], or by selection, as in [186], adding data to global models [187], perform better in EPS [188], and in weighted EPS [189] Regarding seasonal mean rainfall, coarse and high-resolution RCMs are in agreement if they are convection-permitting and the GCM is reliable [190].

Climate is a major water scarcity driver through its influence of global and regional interannual variabilities of precipitation as in the vulnerability of global water resources from climate change [191], climate change and water [192], climate change and changes in global precipitation patterns [193], regional and impact-related climate targets [194], the relationship between climate forcing and impact [195], and climate change at different levels of global temperature increase [184]. Short term variations are connected to long term ones [196] and in [197] regarding connection with seasonality. In terms of extreme rainfall, there is a link between these and temperature in tropical climates, where there is an increase in warm periods and a decrease in cold periods [198]. Additionally, climate-driven interannual variability of water scarcity impacts food production [199], in [107] regarding climate change on renewable water resources at the global scale in combination with population increase, in [200] regarding drought creating anthropogenic climate change, in [201] global assessment of the impact of climate change on water scarcity.

It should be pointed out that, in the case of precipitation models, including precipitation extremes, grid refinement plays a major role and general circulation models (GCMs) have been substituted by high resolution Regional Climate Models (RCMs) which labour under two problems, that of the requirement of specification of lateral boundary conditions as they impede self-consistent interactions between global and regional scales of motion [202] and that of the fact that simple resolution increases lead to very limited improvements in the long forecast range without model improvements, i.e., reconsideration of the physics picture [203]. Notably, high-resolution models perform better for East Asia than for India [204]. Blue water sources such as lakes influence climate through the carbon cycle $[205,206]$ and modify the climates of their surrounding areas up to synoptic scale [207]. At the same time there is a definite trend of rapid and highly variable warming of lake surface waters [208], and a study of 20 Danish lakes showed for the period 1989-2006 where a surface water warming of $\sim 2{ }^{\circ} \mathrm{C}$ and a cooling of deep water of $\sim 1^{\circ} \mathrm{C}$ were found [209]. The effect of the climate changes can be seen in [210] with respect to the Amazon and La Plata basins and in [211] regarding the Yarlung Tsangpo-Brahmaputra River (YBR) impacting assessed in China, India, Bhutan and Bangladesh, where in terms of RCP8.5 conditions, by 2035, the flow will increase by $12.9 \%$ (Bahadurabad, Bangladesh), $13.1 \%$ (upper Brahmaputra outlet) and 19.9\% (Nuxia, China) relatively to the 1980-2001 period. In terms of precipitation trend due to climate change, the general guiding principle that, in the subtropics dry areas become drier and in the mid to high latitudes wet areas become wetter holds true [212], as seen in the transition to a more arid climate in Southwestern North America and in the trend of wet seasons becoming wetter and dry seasons becoming drier [213], and, in [16], climate caused changes in precipitation patterns have influenced total amounts of rainfall and extreme events (droughts and floods). In a warm climate, the anthropogenically caused increase in atmospheric water subject to precipitation leads to an enhancement of either moisture convergence or divergence increasing variability of precipitation water in a warmer climate enhances moisture convergence or divergence during wet or dry years, consequently increasing precipitation variability $[214,215]$.

Additionally, in [216] adverse climate change will lead to reduced water availability in the countries that are already water scarce and to an increase in the variability with which the water is delivered. Climate variability impacts are found for both blue and green water and human water use affects regional climate [217], blue and green water 
resources under CMIP3 and CMIP5 models [218], blue water in the Athabasca River Basin, Canada [219], groundwater [220], groundwater storage [221], river basins in the Western USA [222], impacts on hydrology and water resources in the Blue Mountains, Oregon, USA [223], in the making water resources in Phoenix, Arizona, vulnerable [224], and observed streamflow, evaporation, drought trends and water resources in the USA [225]. Impact of soil moisture-climate feedbacks on CMIP5 projections are shown in [226] and there is model agreement on forced response pattern of precipitation and temperature extremes [227]. In addition, $25 \%$ of exorheic river basins run dry without reaching the sea [228], and some are periodically dry, e.g., the Yellow river, the Colorado River, and the Ganges river [61], this being usually attributable to irrigation water withdrawals and associated evapotranspiration (ET) increases [229] due to aridity and semi-aridity [230].

As can be seen in [231], the most common climate type by land area is $(14.2 \%$, Hot desert) followed by (11.5\%, Tropical savannah) and in the Köppen-Geiger Maps for the periods 1980-2016 and 2071-2100 there is a marked change in climate. At the same time some regions are chronically more sensitive to water withdrawals and availability than others [232], e.g., India, northern China, north and sub-Saharan Africa, the Middle East, and parts of Eastern Europe [233].

Besides flowing water, groundwater is climate influenced, as seen in [140] and in [234], in the central high plains aquifer, in strategic mid-latitude aquifers (such as in the Central Valley in California) and the aquifer beneath the upstream regions of the Indus River and Ganges River in Northwestern India, among others [235], as well as in climate-induced increase in pumping [236].

A closer look at some the world's more indicative regions follows.

\subsubsection{Europe}

In the EU (2012), with a total area of $4.3 \mathrm{M} \mathrm{km}^{2}$, river basins make up an area of $987,914.5 \mathrm{~km}^{2}$ (23\% of total area) and suffer summer water stress. River basins with an area of $460,521.9 \mathrm{~km}^{2}$ (10.7\% of total area) suffer year-round water stress, while the corresponding projections for 2030 are 1,934,998 $\mathrm{km}^{2}$ ( $45 \%$ of total area) and 1,288,885 $\mathrm{km}^{2}$ (30\% of total area), respectively [237].

While climate variability impacts blue and green water fluxes in Europe [238], in terms of RCM models, or otherwise, a rise in mean and extreme precipitation is projected for Northern Europe, as seen in a climate change simulation for Europe [239]; this attributing precipitation to changes in synoptic circulation [240], in an intercomparison of scenarios from regional climate models [241], in an ensemble of regional climate simulations [242], to an exploration of regional climate model projections [243], to human contribution and precipitation extremes [244], while the 20th century showed a precipitation increase in Northern Europe by 10-40\% [245], and in an analysis of a high-resolution climate change scenario [246], as well as in a high atmospheric river (AR) contribution to precipitation [247]. In the Mediterranean region of Europe, the converse is projected, a reduction in mean precipitation with an increase in extreme values, as seen in an increase of extreme daily rainfall in the Mediterranean, but a decrease in total values [248], increase in precipitation in northern Europe and decrease in southern Europe is attributed to a poleward shift of the North Atlantic storm track [249], and there is low atmospheric river (AR) contribution of atmospheric rivers to precipitation in Southern Europe [247], which is confirmed by the fact that the first empirical orthogonal function (EOF) with S-PC 1, explaining $12.8 \%$ of total variance reflects the North-South contrast, which implies that oscillations are not "well-related" to the North Atlantic Oscillation (NAO) index [250]. In fact, that the contrast between the trends in Northern and Southern Europe may depend on the choice of index, e.g., it is more diffuse for S95pTOT than for R95pTOT [251], in simulation using a regional climate model [252], in regional climate simulations for Europe and the Alpine Region [253], while total precipitation will decrease over most of the considered domain from a high resolution double nested RCM simulation [254]. The effects of climate change can be seen in [255] regarding Portugal, while, in Northern Europe, the picture of changes in 
extreme precipitation is approximately the same as that for the trend in total precipitation amount, and in Southern Europe, the same happens in winter, albeit slightly wetter in other seasons [256]. In [257], climate leads to a decrease in available water resources of $>10 \%$ in Central, Eastern and Southern Europe. Climate variability alters partitioning between the runoff sources and flow regimes in Swiss Rivers [258] and causes warmer summers to have more green and less blue water in the Alps [259]. For the period of 1979-2009, monthly precipitation trends of circulation changes seem to be of importance in Northern Europe in February and December, explaining wetting trends in Northwestern Europe in July, while, in the Mediterranean, February was dry relative to the rest of Europe [260].

\subsubsection{Africa}

Of particular interest is Africa in general, despite the fact that in Figure 6, water scarcity is mainly attributed to economic scarcity, as precipitation is due to deep convection, which is the result of a hydrodynamic instability in the troposphere [261], climate change will amplify existing stress on water availability [262]. Its 2015 population of 1.19 billion has a median projection of increasing to 1.68 billion people in 2030 ( $42 \%$ increase) [263], and the problematic sub-Saharan region, in particular, with a 2015 population of 995.5 million [264] and 2030 projection of 1.4 billion [265] (40\% increase). In addition, climatic changes impact river runoff, increase blue water demand. and increase the risk of shallow groundwater contamination via intense rainfall [225]. Evaporative losses in the Zambezi are increasing [266] and, in [257], climate leads to the decrease of available water resources by $>10 \%$ in Okavango and Limpopo in Southern Africa. In addition, the tropical mechanism is such that if the air above the Indian Ocean boundary layer warms up it will impact Africa by reducing the local precipitation, leading to hydrodynamic stability, which results in a reduction in precipitation [267].

In general, the variability of interannual rainfall is high, as shown in [268], where the Africa Rainfall and Temperature Evaluation System (ARTES) was employed, especially in the Sahel region [269]; and a new concept had to be introduced, that of near-surface storage, to address evaporation losses from rain falling on dry soil [270]. This was shown in a study in Nigeria where, out of rainfall, only $12 \%$ becomes green water while $70 \%$ evaporates without penetrating the soil to such a depth where it could become green water [271]. Decreasing stream flows for rivers in Sudan and increasing discharge for those in the Sahel were found in $[272,273]$. In terms of groundwater, the predictions are that recharge will increase in Sahel and decrease in South-West Africa [274] and a review of these estimations for the entire continent is presented in [275]. In [276], climatology, annual cycle, and interannual variability of precipitation and temperature are simulated over West Africa, and climate variability impacts are shown for west African rivers [277]. In [278], Sahel, West Africa (WA) and Southern Africa (SA) are identified as CMIP5 type climate change hotspots, and there is oceanic forcing of precipitation in the Sahel [279], as well as that historical analysis predicts substantial drying over much of the Sahel and East Africa during the primary growing season by the end of the century [264]. It should be noted that there are about 80 river and lake basins in Africa, 21 of which are used by over 10 sovereign states [280] and misuse of upstream water privileges could lead to an "water war", a conflict centered on water scarcity and trans-boundary water sources [280,281]. In general, future trends lead to that Mediterranean Africa and the Northern Sahara will suffer a decrease in annual rainfall, which will intensify at the Mediterranean coast and in southern Africa's winter rainfall region. It will increase in East Africa while the Sahel rainfall increase will be balanced out by evaporation [282]. Regarding precipitation projections over the Democratic Republic of Congo, changes in both frequency (RR1) and daily mean intensity (SDII) lead to a tendency towards less frequent but more intense precipitation, while in Botswana, Zimbabwe and Mozambique, RCMs project a robust decrease in both mean precipitation and frequency (RR1), with a consequent increase in the number of consecutive dry days (CDD), up to more than 12 days/season. In Somalia there will be an increase in 
annual and SON mean precipitation, together with an increase in both maximum daily intensity (RX1 day) and frequency of extreme events (R10 mm) [283].

\subsubsection{Asia}

In [222], projected precipitation changes over the south Asian region for every $0.5{ }^{\circ} \mathrm{C}$ increase in global warming are shown. In [257], it is shown that climate leads to a decrease in available water resources by $>10 \%$ in the Zhu Jiang catchment in southern China, in [284], future rainfall events are likely to be more intense, leading to run-off water losses and rivers in South Asia are likely to exhibit decreased summer flows (after an initial increase) and increased winter flows, which leads to the necessity of increased storage facilities. In [285], climate induced decrease in the summer monsoon rainfall in 2009 caused the most severe drought experienced in Southeast Asia since 1875, and exceptions from normal years in terms of drier and wetter years, and records for the highest and lowest temperature were observed around the globe during the 2000s. Climate variability impacts on both blue and green water in the Upper Ganjiang river basin in China [286], the Erhai Lake Basin of Southwest China [287], the Taihang Mountain Region, China, over the past 60 years [288]. Flows under natural conditions in inland river basins in Northwest China are covered in [289], blue water in India in [290], green and blue water over Asian Monsoon Region in [291], and blue water from snow and glacial melt for Asian river basin hydrology in [292]. In South Asia rainfall intensity has increased but the number of wet days has been reduced [293]; thus, increasing blue water consumption. Under RCP4.5 and RCP8.5 scenarios, using an increase of $1.5-2.5^{\circ} \mathrm{C}$, daily precipitation extremes could increase by 4 to 6 times over India, while annual mean precipitation would be insignificant at the $1.5{ }^{\circ} \mathrm{C}$ level. Regarding Bangladesh, Bhutan, India, Nepal, Pakistan and Sri Lanka, by the end of the twenty-first century the country-averaged annual mean precipitation is projected to increase by $17.1 \%(2.2-49.1 \%), 18.9 \%$ ( -4.9 to $72 \%), 27.3 \%(5.3-160.5 \%)$, $19.5 \%$ ( -5.9 to $95.6 \%), 26.4 \%$ (6.4-159.7\%), and $25.1 \%$ ( -8.5 to $61.0 \%)$, correspondingly by the end of the twenty-first century under the SSP5-8.5 scenario (uncertainties in parentheses whose size speaks volumes) [294]. From the 50s to the early 2000s, Southern Vietnam, the northern part of Myanmar and the Visayas and Luzon Islands in the Philippines see heavy precipitation increases and northern Vietnam sees decreases [295]. Over South Asia, extreme precipitation occurs mainly during the summer and autumn, accounting for more than $40 \%$ of the total precipitation in winter over India and it occurs during all seasons over Southeast Asia, exhibiting a decline in the autumn and a maximum in winter [296]. Aridity is expected to increase in Central Asia, along with high temperatures in summer and fall, and decreased precipitation, particularly in the western regions of Turkmenistan, Uzbekistan, and Kazakhstan [297]. A comparison of Asian precipitation between 1920's and 1990's is shown bellow.

\subsubsection{WANA Region and the "Arc of Crisis"}

The Western Asia and North Africa (WANA) region (Algeria, Morocco, Tunisia, Libya, Egypt, Eritrea, Ethiopia, Sudan, Turkey, Cyprus, Iraq, Israel, Jordan, Lebanon, Syria, Iran and all countries in the Arabian Peninsula, Pakistan and Afghanistan), which is, in essence, the IMF MENAP region [298], has the lowest per capita renewable water resources [299] and includes, in part the "Arc of Crisis" (Somalia, Sudan and Egypt, Yemen, Iraq, Pakistan and Afghanistan) [300]. Leading to 2025 (base year 1995), the WANA region is expected to continue over-pumping, with SMAWW (surface maximum allowed maximum water withdrawal) and GMAWW (groundwater maximum allowed water withdrawal) increasing at annual rates of $0.66 \%$ and $0.12 \%$ respectively, while population will increase by $66.1 \%$, GDP/capita by $88 \%$, irrigated area by $18.4 \%$ and livestock production by $87 \%$, all of which influence water supply and demand [301]. Algeria has an estimated 30\% rain deficit, impacting watercourse flow regimes, siltation reduced dam storage capacity by 2 to $3 \%$ per year and groundwater level dropped below $20 \mathrm{~m}$ [302]. Due to climate variability the country's center, west and some province of the east are the most vulnerable to the 
upcoming (2027) water resources deficit [303] while acute climate sensitivity is expressed with a hydrological water stress index (HWSI) of 33.5 and a reversed water poverty index (RWPI) of 47.9. The semiquantitative evaluation of temperature changes in absolute terms $(\Delta T)$ are in the bracket $0.5^{\circ} \mathrm{C}<\Delta T<1{ }^{\circ} \mathrm{C}$ [304] and all model simulations predict expansion of the desert climate zone at the expense of both temperate and steppe climate zones [305]. Somalia, taking into account annual average rainfall pattern, has a sub-humid to desert climate, two rainy seasons and two dry seasons, and the climate is influenced by an inter-tropical convergence zone (ITCZ) and the Somali jet [306]. It has an estimated available water of $14.7 \mathrm{~km}^{3}$ with an annual withdrawal rate of $3.3 \mathrm{~km}^{3}$ and water ownership belongs to the private sector, where high prices are imposed [307]; there is a state of perpetual armed conflict, and half the primary water sources are serviceable and 2.7 million people are in need of humanitarian aid, which includes the need for water [280]. Yemen's water supply was about $1100 \mathrm{~m}^{3}$ / capita/year in the 1960's, near the water poverty line; by 1990 it dropped to $460 \mathrm{~m}^{3}$ / capita/year. Water gathering using standard fog collectors (SFC) was tested in Hajja in 1989 and found to be promising [308]. By 2012, water supply dropped further to $120 \mathrm{~m}^{3}$ /capita/year while the current national population growth rate is about 3.5\% annually and over two million Somali immigrants have been accepted as refugees [309]. In Sana'a, Yemeni farmers increased water well depth by $50 \mathrm{~m}$ over a 12-year period, but despite this, the extracted water was diminished by $66.6 \%$ [300]; the water table is declining in average by about $6-7 \mathrm{~m}$ annually due to groundwater overabstraction [310] and fresh water withdrawal/available freshwater resources was 170\% in 2014. Egypt suffers from explosive population increase, from 90 million in 2015, going on to 140 million in 2037 and 170 million in 2050 which correspond in Nile water/capita/year, to $611 \mathrm{~m}^{3}$ /capita/year, $392 \mathrm{~m}^{3}$ /capita/year and $324 \mathrm{~m}^{3}$ /capita/year respectively [311] The incoming volume of Nile water is constrained by treaties with Soudan [312] and by the Grand Ethiopian Renaissance Dam (GERD), where filling the dam will disrupt the flow into the Egyptian part of the Nile and the post-filling period might include a severe multi-year drought [313]. Pollution is highly problematic [314] but the main long-term dangers arise from climate interaction, seawater rise threatening the Nile Delta [315], climate variations and change to the Nile in terms of climate and hydrology of the Upper Blue Nile River [316], as well as impacts from climate change on Blue Nile flows [317], sealevel rise and climate change impacts on the lower Nile delta [318], and, in the future, hot and dry years will worsen Nile Basin water scarcity [319]. Increased water requirement due to higher temperatures will occur as evaporation from the High Aswan Dam is over 10\% of the Nile flow [320]; an increase by $3-3.5^{\circ} \mathrm{C}$ may be manifested by 2060 [321,322]. Climate change affects Arab countries [323] and the work in [257] shows that climate leads to the decrease of available water resources by $>10 \%$ in the catchments of the Euphrates/Tigris in the Middle East, a decrease in Syrian precipitation from a combination of natural variability and a long-term drying trend [324], while climate variability will impacts the water resources of the Greater Zab River, Iraq [325]. In the cities of Riyadh, Jeddah, Mecca, Medina, Al-Ahsa, Ta'if, Tehran, Mashhad, Isfahan, Karaj, Tabriz, Shiraz, Qom, Ahvaz and Baghdad a baseline water stress $>80 \%$ is expected [326].

\subsection{Action at a Distance}

\subsubsection{Climate Teleconnections}

However, teleconnections, "statistically correlated climate-related patterns between remote geographical regions of the globe" [327] or "a cause-and-effect chain that operates through several intermediate steps and leads to a linkage between two parts of a system" [29], influence precipitation, as in the case of the upper Medjerda Basin [328], the modulation of ENSO-precipitation teleconnection by the interdecadal pacific oscillation [329], across the combined North American, monsoon Asia, and Old World drought atlases [330], predictability of winter precipitation in Southwestern US via interhemispheric teleconnection [331], the case of water level regime of selected Polish lakes [332], the global influence of the ENSO-Indian monsoon [333], and, therefore, it may be considered that 
part of local precipitation is indirectly "imported" or "curtailed" as a result of the imported change of the conditions influencing its quantity. Precipitation-shed algorithms [334] lead to the computation of teleconnectional spatial dependence for any specified rainfall portion over any specified area. The most well-known case of influence via teleconnection across the globe impacting at a regional scale is the El Niño Southern Oscillation (ENSO) via temperature on precipitation [335] and a quantification of the probability of the occurrence below normal, near normal, and above normal values of precipitation and near-surface temperature in relation to ENSO is presented in [336].

The distance of teleconnection influence may rise to thousands of kilometres e.g., Upper Blue Nile Basin rainfall and flows are influenced by the El Niño Southern Oscillation (ENSO) as in link to the Blue Nile River Basin hydrology [337], climate teleconnections and water management [338], summer rainfall over the source region of the Blue Nile [339], influence on the natural variability of the Nile River [340], and on precipitation and surface temperature over the Upper Blue Nile Region [341]. Influences extend to Caspian Sea level variability [342], as well as the west and northwest of Iran, west coasts of the Caspian Sea and the Southern Alborz Mountains [343]. They also extend to seasonal precipitation [344] and summer climate in China [345], to Mediterranean precipitation variability [346], European winter precipitation anomalies [347]. The North Atlantic Oscillation Index (NAOI) extends to Lake Windermere [348]. Additionally, the warming of the Indian Ocean is expected to disrupt rainfall in Eastern and Southern Africa, increasing undernourishment by $50 \%$ by 2030 [349]. Groundwater is subject to teleconnection influence such as in nonstationary groundwater level response [350], groundwater level response in U.S. principal aquifers [351], as well as climate forcings on groundwater resources of the USA's West Coast [352]. ENSO is also influenced by drought as in projections of future groundwater drought [353], drought and climate teleconnection [354], in Iran [355], China [345], as well as a series of droughts in the USA in 1988 [356], Further works address the turn of the century [357], droughts in general [358], in mainland Southeast Asia [359], in Northern Chile [360] and East African drought during rainy seasons [361]. Flood occurrence is influenced as well shown by the 2010 Pakistan flood and the Russian heat wave [362], as well as in Iran's Kan River basin [363], in the Southern Great Plains [364], the Missouri River Basin [365], the Yangtze River [366] and on a global level [367]. There is also extreme precipitation in North America [368], Central-Eastern China [369], over China in general [370], as part of the ENSO asymmetric effect [371], and in Northern South America [372]. Extreme precipitation relationships in the Mediterranean region exist [373], as well as variability of extreme precipitation over Europe [374] and on variability analysis of extreme precipitation in Turkey [375].

\subsubsection{Evaporation and Moisture Import/Export}

Based on work in $[376,377]$ on the recycling ratio (RR) of the two-dimensional extension of the Budyko model [378], and its variants/extensions (also in [379] and a review of models in [380]), the fraction of precipitation over a defined region that originated as evaporation from that same region led to an assay at the national level of evaporative sources and sinks [381,382]. This was an estimation of how much precipitation was due to local and non-local evaporation and the determination of the nationality of non-local evaporation based on the classical equation, $P=P_{L}+P_{A}$, where the left side $(P)$ is total precipitation and the right side is the sum of precipitation originating from local evaporation $\left(P_{L}\right)$ and on advected evaporation $\left(P_{A}\right)$. The method used was a quasi-isentropic back-trajectory (QIBT) scheme $[383,384]$ which was performed on global gridded precipitation data found in [385] employing multiple tracers of atmospheric moisture [386], of which the paths were calculated using reanalysed fields of winds and temperature from [387]. A list of countries and their import-export properties are presented in [382] and a connection is shown by the result that, under certain conditions, water vapor is exported from less humid countries to more humid ones. Similar work was compiled for Central Europe, the Balkans and Spain [388], Colombia [389], atmospheric rivers over the West Coast of the United 
States [390], for summer rainfall in the Southwest United States [391], in China [392], in the connection of water sources and precipitation recycling in the MacKenzie, Mississippi, and Amazon River basins [393], and in the Orinoco basin in Equatorial South America [394].

Terrestrial evaporation import/export, where in the case of import, advective precipitation is produced [395], is based on the notion of 'precipitationshed', "the upwind atmosphere and upwind terrestrial land surface that contributes evaporation to a specific location's precipitation (e.g., rainfall)" [396]. This is a form of teleconnection which may go down to smaller distances under particular conditions, which in essence is a land-sea area, enclosing the source of terrestrial evaporation surrounding the sink which receives the precipitation. Physically it is moisture recycling which returns via the atmosphere as downwind precipitation [397]. Western Sahel, Northern China, and La Plata are considered to be sink regions dependent on land moisture imports [334]. Forty percent of precipitation in certain Eastern Africa arid regions are connected to irrigation agriculture in Asia [398] and influences precipitation in the Amazon Xingu Basin [399]. In addition, 19 out of a total of 29 megacities were found to be dependent, in excess of $33 \%$, on the precipitation shed mechanism for water, four megacities were already suffering from a series of problems [400]. Karachi (also suffering from supply problem, contamination, revenue recovery, industrial pollution and climate change), Shanghai (also suffering from pollution, salt water intrusion, the influence of major hydraulic projects and flooding), Wuhan and Chongqing (also suffering from pollution and wastewater treatment), were found to be highly vulnerable to the land change of the source component [401].

\subsection{The Direct Human Intervention Scarcity Driver}

Another major water scarcity driver is direct human intervention (HI) (land use and land cover change (LULCC) [402,403], man-made reservoirs for electricity generation, increase of wealth and human water use due to population increase [404]), which increases water scarcity for $8.8 \%(7.4-16.5 \%)$ of the global population, which is downstream but decreases it for $8.3 \%(6.4-15.8 \%)$ of the global population which is upstream [405]. Human intervention in terms of dams, due in part to increased surface evaporation [404], and water withdrawals, is seen to be have a more powerful impact than the climate [406]. LULCC also is directly related to population growth [407]. The anthropogenic greenhouse era may have begun thousands of years in the past, and not 150 to 200 years ago during the Industrial Revolution, as is the going hypothesis [408], and, in terms of net photosynthetic accumulation of carbon by plants, which is defined as net primary production (NPP) consumption, this has doubled in the 20th century [409]. This has led to a 31-32\% consumption of the total amount of NPP generated on land [410,411]. Also, in [412] for total 2009 NPP prediction of 50.05 Pg C, an increase of +0.14 Pg C during the period 2000-2009. In [413], human activity induced climate caused temperature increase, leading to water resource reduction, which was the same in [414] and consequences are analysed in [415]. In 2016, human water use via the consuming (producing) of primary and manufactured goods and services from "primary crops and livestock", "primary energy and minerals", "processed food and beverages", "non-food manufactured products", "electricity", "commercial and public services", and "households" sectors accounted for 33\% (91\%), 0\% (1\%), 37\% (<1\%), $13 \%(1 \%), 1 \%(2 \%), 15 \%(3 \%)$, and $2 \%(2 \%)$ respectively, of the world's total blue water consumption [416]. In addition, according to the planet boundary theory, human impact is amplified by its interaction with the Earth system [417].

\subsubsection{Land Use and Land Cover Change}

During the period 1700-1990, cropland increased from $2.6 \times 10^{6} \mathrm{~km}^{2}$ to $14.71 \times 10^{6} \mathrm{~km}^{2}$ $(565 \% \uparrow)$ and pasture land increased from $5.24 \times 10^{6} \mathrm{~km}^{2}$ to $34.51 \times 10^{6} \mathrm{~km}^{2}(658 \% \uparrow)$; the world population went from 605.4 million to 5301.8 million (875\% $\uparrow$ ) [418]. During the period of 1700-1989, irrigated cropland went up from $0.08 \times 10^{6} \mathrm{~km}^{2}$ to $2 \times 10^{6} \mathrm{~km}^{2}$ $(2500 \% \uparrow)$, grassland/pasture remained approximately the same, and during 1700-1983 forest/woodland dropped from $61.51 \times 10^{6} \mathrm{~km}^{2}$ to $52.37 \times 10^{6} \mathrm{~km}^{2}(14.86 \% \downarrow)$ [407]. 
It should be pointed out that the availability of land resources and local natural conditions [419] impose a nominal limit of a total cropland availability, in the range of $2.7 \times 10^{9}-3 \times 10^{9}$ ha $[420,421]$, half of which is already cultivated [422]. Cropland expansion is virtually impossible without deforestation [423], a climate driven calculation which places it in the region of $300 \times 10^{6}$ ha to 2050 [424].

Land use land cover change (LULCC) reshapes water provision [425], the resulting deforestation raises the water table and, if the underlying layer is problematic, e.g., salty as in the case of Australia, it results in soil destruction and, in general, it mediates the trade-off of ecosystem services depictable in the three dimensional framework of (space, time, reversibility) [426], in particular of freshwater ecosystem services (FES) as in the case of Bangladesh, where long term reduction is traced to LULLC [427]. Moreover, deforestation reduces the flow of green water to the atmosphere, which increases the time needed for moisture recycling. However this is balanced out by evaporation from compensating increased irrigation demand [428]. LULCC is caused by biophysical constraints and potentials, economic factors, social factors, irreversibility and uncertainty, spatial interaction and neighbourhood characteristics and spatial policies at national and subnational level [429]. At a global scale, proximate LULCC drivers are agricultural expansion, urban growth, infrastructure development and mining, which are responsible for $80 \%$ of deforestation [430], while, in another study for the period $1990-2008,46 \%$ went for livestock pasture, $11 \%$ for crops for animal feed, and the remaining $43 \%$ for agriculture [431]; at the global-continental scale climate, freshwater availability and soil are the drivers behind land use patterns [432].

In addition, "land-grabbing" type investments are a cause of LULLC e.g., in Africa there were 84 deals of 100,000 ha or more, out of 190 at a global scale, of which 2 deals in Sudan and the Congo Republic exceeded 1,000,000 ha [433]. These diminish the availability of blue water to others, since $18 \%$ of these $(91,000 \mathrm{ha})$ require more than $50 \%$ of water from blue water sources [434]. In the tropics, agriculture is the main driver [435], while in developing countries commercial agriculture accounts for $40 \%$, subsidence farming for $33 \%$, mining for $7 \%$, urban expansion for $10 \%$, and infrastructure for 10\% [436]. Additionally, the main drivers for deforestation in Argentina, Bolivia, Brazil, Paraguay, the Democratic Republic of the Congo, Indonesia, Malaysia and Papua New Guinea, in the period of 2000-2009, were beef, soy, palm oil, and wood products [431]. LULCC affects the climate via regional energy fluxes, impacting precipitation trends [437] and temperature [438] and, hence, intervenes actively in the hydrological cycle [439]. Its impact on climate is on local [440,441], regional [442] and global scale [443,444], may dampen or enhance the impacts of increasing $\mathrm{CO}_{2}$ [445] with temperature consequences, is a main cause of soil degradation [446], which may lead to increased LULLC, alters the planetary boundary layer (PBL) structure by enhancing the vertical movement of air [447] and, if the area is large enough, it affects remote areas' rainfall via teleconnection. This is shown in an assay of the influence of land-use change and landscape dynamics on the climate system in [448], in hydro-climatological teleconnections resulting from tropical deforestation [449] and the impacts river flows as well [450], reductions in run-off as in the Guishui River Basin, China (where a 5\% reduction was found) [451]. Land-atmosphere coupling induces climate change in Europe [452]. In [453] during the 1953-2001 period, expansion exceeding $5 \%$ significance in the areas of arid $\left(4.2 \times 10^{5} \mathrm{~km}^{2}\right.$ decade $\left.^{-1}\right)$ and continental climate $\left(2.3 \times 10^{5} \mathrm{~km}^{2}\right.$ decade $\left.{ }^{-1}\right)$ north of $55^{\circ} \mathrm{N}$ and shrinkage of polar climate $\left(-2.9 \times 10^{5} \mathrm{~km}^{2}\right.$ decade $\left.{ }^{-1}\right)$ and continental climate $\left(-3.2 \times 10^{5} \mathrm{~km}^{2}\right.$ decade $\left.{ }^{-1}\right)$ south of $55^{\circ} \mathrm{N}$ was found. In non-Amazonian South America, where the environment is semi-arid and the population is around 200 million, LULCC is already causing water stress and reduced agricultural productivity as more than 3.6 million $\mathrm{km}^{2}(58 \%$ of their potential natural vegetation) has been lost and may impact the Central Andes and Chilean Matorral where a weaker hydrological cycle is projected along with increased risk of lower water availability [454]. Similarly, in the Brahmaputra Basin, using a SWAT model with calibration parameters, such as surface runoff, groundwater, snow, ET, and the routing process for the basin's hydrology, it was found that a LULCC to agriculture scenario of $72 \%$ by 2070 
would shift precipitation from the monsoon months towards the winter, thus increasing drought risk during early monsoon months [455]. In the case of the Jedeb mesoscale catchment, Abay/Upper Blue Nile basin, Ethiopia LULCC during 1973-2010 caused the soil moisture condition parameters to follow a gradual decreasing trend, increasing surface runoff in terms of high flow by $45 \%$ in the 1990-2000 decade while low flows decreased by $15 \%$ in $1970-1980,39 \%$ in $1980-1990$, and up to $71 \%$ in $1990-2000$ [456]. A study on annual surface runoff and evapotranspiration was done, in the same general region, for the drought prone watersheds of Kasiry (highland), Kecha (midland), and Sahi (lowland) for 1982-2016/17, which showed runoff increases from $4 \%$ in Kecha to $28.7 \%$ in Kasiry and evapotranspiration ranged from $15.8 \%$ in Kasiry to $32.8 \%$ in Kecha despite climate variability induced evapotranspiration increase, ranging from $33.6 \%$ in Kecha to $42.1 \%$ in Kasiry [457]. Global land cover annual maps for the period 1992-2015 are in [458].

Sub-Saharan Africa, during the period 1975-2000, showed (using a stratified sampling strategy) a $57 \%$ increase in agriculture area, from 200 Mha to $340 \mathrm{Mha}$, at the cost of a $21 \%$ loss of forest and non-forest natural vegetation per year; in total, 131 Mha and an increase in barren land by $15 \%$ (6.5 Mha) [459].

However, climate (temperature) and precipitation sensitivity are an issue in LULLC e.g., the southern provinces of Canada, northwestern and northcentral states of the the United States, Northern Europe, the Southern Former Soviet Union and the Manchurian plains of China, are temperature-sensitive while the Great Plains region of the United States and Northeastern China are precipitation sensitive [460]. A strong relationship is observed between temperature and LULLC in general and between rainfall and LULLC in Southeast Asia in particular [461], where under RCP4.5 LULCC accounts for $<10 \%$ of the projected temperature rise, averaged over sub-regions, but at the local scale may account for up to about 30\% [462]. In South America, local impact of LULLC changes mesoscale circulation patterns, increasing natural vegetation productivity by $10 \%$ in the northwest and decreasing it in the southeast [463]. Sensitivities of surface temperature to LULLC, which induce biophysical changes, are scale-dependent due to atmospheric feedbacks [464].

\subsubsection{Population Growth}

Water scarcity is also caused by high-population pressure under the conditions of limited water availability [465], as according to the interpretation of the Ehrlich-Holdren equation, $I=P A T$, where $I$ is the negative impact on our life-support systems caused by our species, $P$ is the population size, $A$ is consumption per capita and $T$ is the measure of the technology servicing and driving consumption [466] (p. 58) and holds true only for a homogeneous country-wide study [467]. An increase in population is bound to increase water consumption, and increasing demand for water in this way outbalances the effects of global warming and is directly related to population growth [191]. In [6] it is pointed out that population growth is responsible for the increase of both water and agricultural production. Further, population is directly connected to climate, such as under the condition of constant productivity and technology. In the long run, global temperature is logarithmically related to population, if population growth is constant then temperature may be linearly related to it [468], as well as to land human carrying capacity, defined as "the maximum population that can be supported at a given living standard by the interaction of any given human-ecological system" [469] (p. 121). A modern theory of population dynamics takes into consideration agricultural production, the crop prod. Index, and access to water, as seen in [470]. Notably, renewable internal freshwater resources per capita (cubic meters) went from 13,403 in 1962 to 5933 in 2014 [471], a 55.73\% drop, while world population went from 3.125 billion in 1962 to 7.254 billion in 2014 [472], a $56.92 \%$ increase and water consumption went up from 1840 billion cubic meters in 1962 to 3990 billion cubic meters in 2014, a $53.7 \%$ increase. This demonstrates a more or less linear type relationship between renewable internal freshwater resources, which are shown to be relatively constant, population and water consumption, which are demonstrably increasing. MENA population went up from 138.47 million in 1962 to 417.9 million in 2014 [473], an 
increase of $201.7 \%$, which is expected to reach 692 million by 2050 [474]. Water demand will go up by 500\% from 2010 levels [475], and this country set has the highest regional deviation from average annual surface water availability (70\%) and water withdrawals as share of surface water availability $(>80 \%)$, with $>80 \%$ of total water withdrawals going to agriculture [476]. Future projections are 9.2 billion by 2050 [477], 9.7 billion by 2050 and 10.9 billion by 2100 [478]. It should be pointed out that climate-induced migration with major triggers drought and desertification [479], e.g., as in the cases of Bangladesh, Ghana, Ethiopia and Sudan [480], and also conflict, e.g., migrations to and from Somalia [481,482] plays a role in population distribution outside the birth-death actuarial projections.

Indicatively, from 1950 to 2010 the relationship between global population and water withdrawal is manifest, the difference in water for agriculture growth being ascribed to intertemporally increased productivity, as seen in Figure 9.

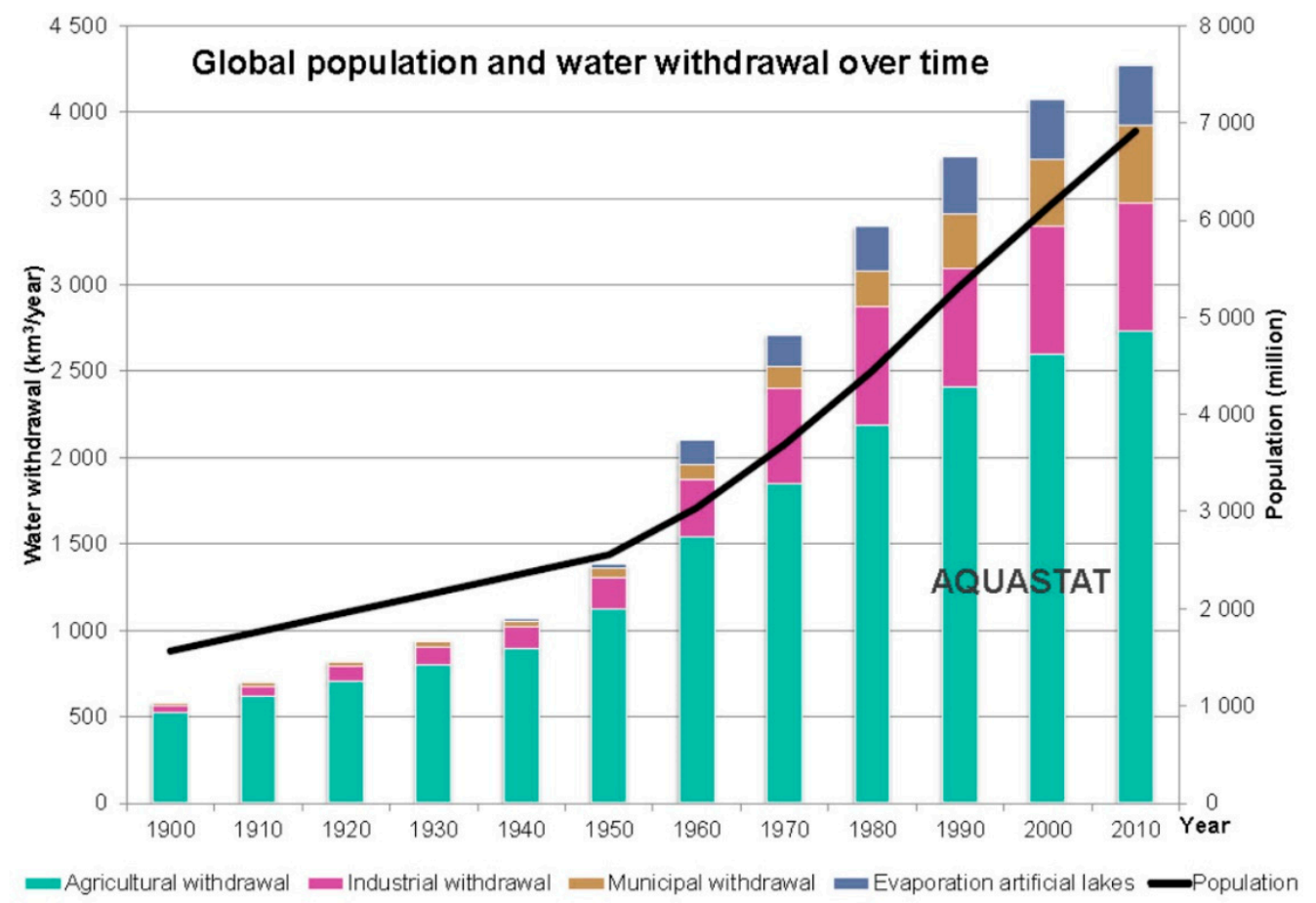

Figure 9. Global Population and Water Withdrawal 1900-2010 (modified from [483]).

Regarding population statistics to date, Africa seems to be moving towards some hybrid form of Shared Socio-Economic Pathways (SSPs) [3] (p. 19), scenario SSP3 in terms of population (comparatively high population growth), to the extent that, by $2100,40 \%$ of the world's population will be in Africa [478] while the other continents are in a slow variability mode or declining, e.g., Europe and Asia.

The relationship between water and population has been discussed and analyzed extensively, e.g., by Falkenmark et al. The interconnection with inadequate amounts of available water, deteriorating water quality, failures in food security, and land degradation, as well as population exclusion due to climate, geography, soil type, latitude, and native vegetation [465], water deficits that would remain in water scarce regions aiming at food self- sufficiency, how those water deficits may be met by food imports and the cropland expansion required in low income countries without the needed purchasing power for such imports have been discussed in [484] and in [14,229]. More recent approaches are in Wada [485], the U.N. 2018 Water Report [486] and its assessment by Boretti et al. [487] and the 2019 U.N. Water Report [488].

As things stand and looking to the future, India and China, the main population components of BRICs, which have stable and organized regimes and economies, may move into the future somewhere between hybrid forms of SSP2 (moderate population growth) 
and SSP1 (low population growth) but Africa and MENA, do not seem to be destined to continue on their present trajectories. Of great interest is the future of the ROW (Rest of the World) countries, which are those that do not belong either to OECD or BRICs, as in 1962 they had a population of 579.6 million which grew by 2010 to 1290 million at an average growth rate of $2.55 \%$ per year and have yet to be examined on a country-by-country basis to start drawing conclusions.

\section{Discussion}

\subsection{Problems with Definitions}

Water is an economic good [1,2] and so are its main components, blue and green water, and therefore, in any "supply-demand" definitions, as in the 2007 U.N. definition in Section 3.1.3, the economic interpretation is on equal footing with any physical one as water allocation, which may induce scarcity for agricultural use, is within the purview of central economic policy, e.g., via use-dependent price discrimination. All definitions should be explicitly limited to available water resources, as unavailability is usually accompanied by incurring the cost of making water available, in terms of money, time and the environmental impact of materials employed via their water footprint, which differentiates it from already available water. The supply-demand approach, as in [47,72], where imbalance happens at "prevailing prices" [79-81], is a bit nebulous as the automatic reaction of an open market in the case of stakeholders (Figure 5) is to seek equilibrium at a higher product price, traversing the stakeholder layers horizontally and/or in the market for alternative uses. In fact, if after a bad season due to water scarcity agriculture adopts a growth pattern to return to previous levels and is henceforth subject to uneven water scarcity, then prices will rise in Baumol's model [489].

In fact, the definition of water in the Dublin Water First Principle, "Water is a finite, vulnerable and essential resource which should be managed in an integrated manner" leads indirectly to that of a Global Public Good defined as "issues that are broadly conceived as important to the international community, that for the most part cannot or will not be adequately addressed by individual countries acting alone and that are defined through a broad international consensus or a legitimate process of decision-making" [490]. Yet, this broad international consensus is contrary to water rich sovereign country's interests and hence its materialization is highly improbable without counterbalancing conditions being imposed to importers.

As Winpenny points out "There are degrees of scarcity" among which "need" is included, the lower bound of the scarcity bandwidth, which has a dual interpretation, that of actual physical need, which represents the closing of the gap between "what is" and "what ought to be" from an objective point of view and that of "felt need", which is based on people's subjective opinions and perceived trends and outlooks [491]. More to the point is Beatty's definition of need "the measurable discrepancy existing between a present state of affairs and a desired state of affairs as asserted either by an "owner" of need ("motivational need") or an "authority" on need ("prescriptive need") [492] while, regarding consumers, Samuelson distinguishes between what people "really want and need" [493] (p. 4) and particular attention should be paid to Thaler's economic theory of the consumer [494] and his position on perception of consumer utility maximization [495]. However, 'need' for humans, the water end users, then requires per capita quantification to be defined, on a short-term basis, a medium-term basis and a long-term basis, where crops production is included, as seen below and in [496], as well as in the case of disasters [497] while Gleick et al [498] recommend 50 L/capita/day but include studies where the bare minimum for survival is 1.8-5.0 L/capita/day. As can be seen below in Figure 10 short-, medium- and long-term levels start from high quality drinking and cooking and end in decreased quality crops production livestock and recreational use in gardens. 


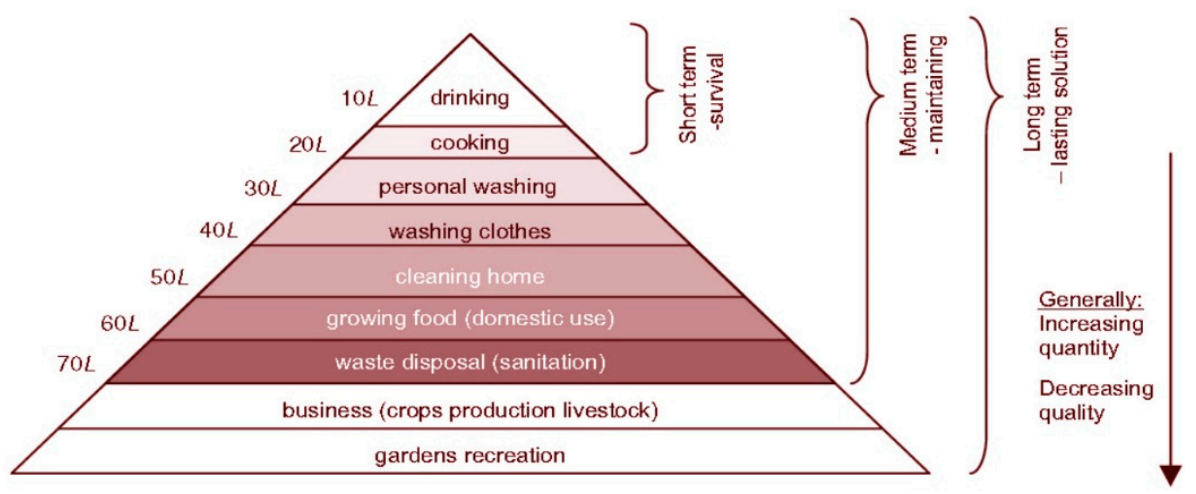

Figure 10. Short, medium and long term levels (modified from [499]).

More narrow types of water scarcity exist e.g., "managerial scarcity" due to inadequate management and maintenance of water resources leading to water scarcity [500,501], "institutional scarcity" caused by lack of institutional capacity to maintain and manage water resources [502], or institutional setting not flexible enough to accommodate changes [503], again leading to water scarcity and "political scarcity" where exclusion is politically imposed or economic policies that lead to scarcity are politically motivated [504].

Water use in terms of agriculture has peaks of demand during the growing season and is therefore a time dependent event which in turn forces demand and supply to be time dependent as well and not static or averaged as most of the scarcity definitions indirectly imply.

Blue water is not separated into water available for use (70\%) and water reserved for supporting ecology sustainability $(30 \%)$, which, if taken as separate entities, would face scarcity conditions separately without complementarity related balancing, but are treated as one entity leading to the assumption that they have the exact same impact, which they obviously do not. Moreover, there is no concept of a hierarchy of demand, set according to globally recognized dangers, e.g., by setting the present and upcoming challenge of food as a priority in terms of water scarcity.

The 2007 U.N. definition does not cover the case where water scarcity may occur in countries with the comparative advantage of low agricultural wages which are usually facing an export-import/balance-of-payments problem and increased food imports, most of which with high virtual water content, redeemable only by the increase of cultivated land and the corresponding increase in water consumption.

The existence of limits such as not using non-renewable water resources, or extending withdrawals beyond the renewable part of those that are renewable, and the percentage allocated to supporting ecology sustainability [505], while being physically correct are within the purview of the economic policy of sovereign states, which, according to their perception of need based primary objectives of their economic policy, may choose to directly or indirectly ignore them.

\subsection{Inequitable Availability}

Resource availability is important and there exist methods, e.g., entropy-based assessment [506] and indices [147], for its measurement, while in [507] blue water availability is defined as total natural runoff net of $20 \%$ assigned to environmental flow requirements and in [60] it is defined as total natural runoff plus groundwater, while in [55] the previous sum is considered net of $30 \%$ assigned to environmental flow requirements. Green water availability is defined in [55] as total rainfall infiltration in agricultural land minus runoff from this area multiplied by a reduction factor for minimum evaporation losses in agriculture of 0.85 . Further, there is a large number of applicative papers on blue and green water resources availability as in Iran [508], in Africa [509], water resources availability is estimated at HRU, river catchment and city/region scales in the Wei River basin, China [510], in an Iranian data scarce watershed using SWAT [511], in the quantitative analysis of provision 
probability [152], county-based green water availability for the entire U.S. [512], under climate change in the Beninese Basin of the Niger River Basin, West Africa [513], availability under climate change scenarios in the Mékrou Basin, Benin [514] and blue water estimates of current and future availability in Europe [515]. Availability indices for both blue and green water are listed in [516]. Groundwater availability is difficult to determine as there is bilateral flow connecting groundwater with blue water and the question of economic feasibility comes into play [517], e.g., there is groundwater in North Africa that is expensive to withdrawal from $150-200 \mathrm{~m}$. boreholes, as pumps may be prohibitive for the prime user group of smallholders, and cost 100,000 USD plus upkeep costs [518]. A regional project may exceed 15 billion USD at 2012 purchasing power parity and levels [519] (while the 2019 national debt/GDP ratio for Tunisia is 72.33\%, Morocco $65.77 \%$, Algeria $46.28 \%$ and Libya is, in effect, a failed state), in the U.S. however, with a much healthier economy, the average well depth, where well water accounts for $>50 \%$ of farm irrigation and all of it is pump extracted, is $72 \mathrm{~m}$. [520]. Future projections for a $2{ }^{\circ} \mathrm{C}$ global climate lead to the conclusion that blue water will show increasingly uneven runoff distribution, which, unless water storage infrastructure is increased, will turn into floods [521].

\subsection{Inequitable Accessibility}

One of the current key problems is inequitable accessibility to water stocks and flows, as many flowing supply sources are sequestered from general dissemination for use due to their adverse location, in terms of population or/and productive land distribution and industry e.g., the Amazon, amounting to $16-20 \%$ of global runoff [522], has a $95 \%$ globally inaccessible flow. The local population to which the water is available does not exceed 35 mil. and Zaire-Congo has 50\%, both being exoreic rivers [523]. The adverse localization of water resources extends to whole countries suffering from water deficit [524]; early studies did not include in-country variations [32], while it seems to be centred in the belt around $10^{\circ}$ to $40^{\circ}$ northern latitude [525] and, in addition, water availability is generally considered to be highly variable over space and time [526]. This uneven spatial distribution of water is manifest in the fact that South and Central Europe has 24-30\% withdrawals, while in Northern Europe it may be less than 3\% [53]. By defining arid zones (hyperarid, arid, semiarid and dry) as those where the rate of evaporation is greater than the rate of precipitation, which have a long geographical history [527], it is found that they cover $41 \%$ of world landmass with a third of the world's population [528], where $50 \%$ of the world's livestock is raised and $44 \%$ of the world's food is cultivated, exclusive of water demanding agricultural produce [529]. On the other hand, 60\% of freshwater is located in nine countries, Brazil, Canada, China, Colombia, the Democratic Republic of Congo, India, Indonesia, Russia (which owns, along with Mongolia, Lake Baikal containing 20\% of global unfrozen water $[530,531])$ and the U.S. [532], and these countries additively constitute $44 \%$ of world landmass with $50 \%$ of the world population [472]. Renewable resources are concentrated in Brazil $\left(8233 \mathrm{~km}^{3}\right)$, Canada $\left(2902 \mathrm{~km}^{3}\right)$, China $\left(2840 \mathrm{~km}^{3}\right)$, Colombia $\left(2132 \mathrm{~km}^{3}\right)$, India $\left(1911 \mathrm{~km}^{3}\right)$, Indonesia $\left(2019 \mathrm{~km}^{3}\right)$, Peru $\left(1913 \mathrm{~km}^{3}\right)$, Venezuela $\left(1320 \mathrm{~km}^{3}\right)$, Russia $\left(4508 \mathrm{~km}^{3}\right)$ and the US $\left(3069 \mathrm{~km}^{3}\right)$ [533]. Still, these countries have internal arid zones e.g., the Southwestern U.S. arid regions [534] and desert southwest [535]. Total inaccessibility of rivers, including the Amazon, the Zaire-Congo and remote rivers of North America and Eurasia which have no dams at all [536] lead to a totally inaccessible remote flow of $7774 \mathrm{~km}^{3} /$ year, amounting to $19 \%$ of total global annual runoff [537]. Inadequate accessibility can happen even in countries with plentiful available water as in the case of Nepal [538].

\subsection{Blue Water Loss}

If blue water discharges from exoreic rivers into the ocean, control of its re-entry into the land system is removed from the region it came from and passes on to the ocean water evaporation system, which may redistribute it, in part or in whole, to other regions. Thus, this may be considered to be a loss of blue water in the regional sense, only but not globally. 
In terms of coastal regions without any exoreic river input to the sea, land precipitation as a function of distance drops at $300 \mathrm{~km}$ from the coast to $750 \mathrm{~mm} \mathrm{yr}^{-1}$ from $1300 \mathrm{~mm} \mathrm{yr}^{-1}$ at the coast line [539], in a recent study, the numbers differed, by taking 1931-2010 average,

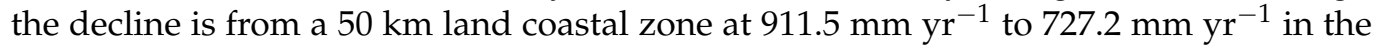
100 to $150 \mathrm{~km}$ off-coast zone [540]. On the other hand, in the almost unique case of the Amazon river, a simulation with and without Amazon discharge into the Atlantic leads to the generation of an impact via teleconnections on the North American and European climates by inducing a NAO phase change [541]. This verifies the initial statement of this section but with an additional proviso. The 2010 Amazon drought was caused in part by increasing Pacific Sea surface temperatures (SSTs) of which the increase was triggered by the low salinity Amazon plume itself, created by the river's discharge into the ocean [542], which may intensify El Niño Southern Oscillation events and, most importantly, associated periodic Amazon droughts [543]. This last impact, in effect, describes a partially selfreaction process caused by the discharge to sea, which is detrimental to the river flow, itself enhancing the regional loss from the discharge. It should be noted that according to an initial estimate, globally $37,288 \pm 662 \mathrm{~km}^{3}$ /year of water amounting to $35 \%$ of terrestrial rain are discharged from exorheic rivers into the sea [544] and in a latter one $45,500 \mathrm{~km}^{3} /$ year [545]. For the global ocean, minus the Arctic, this discharge shows small or downward trends for the largest 200 rivers [546] while a study of the 50 top rivers shows that $57.5 \%$ has a downward trend and $42.5 \%$ an upward trend, mainly due to climatic conditions [547]. Average annual discharge of freshwater from six of the largest Eurasian rivers to the Arctic Ocean has increased by 7\% from 1936 to 1999 [548]. Additionally, uncaptured floodwater amounts to $20,426 \mathrm{~km}^{3}$ /year [537,549] and extreme precipitation leads to increased flood frequency [550]. Flood frequency is analysed by various, including model analysis [551] which are compared in [552], estimation methods were applied in Europe [553], uncertainties were examined in Norway [554] and in China [555], sensitivity for data record, statistical model, and parameter estimation methods in the U.S. [556] and at regional level for Mediterranean basins [557]. Climate change influences flood frequency [558] and is accounted for quantitatively in flood frequency analysis [559]. This is seen in, among others cases, Iran [560], the U.K. [561], the Yangtze basin, China [562] and in the case of extreme floods in Finland [563].

\subsection{Unevenly Distributed Precipitation}

In addition, annual precipitation is unevenly spatially distributed and across seasons leading to green water distortions, impacting agricultural production, as in smallholder and subsistence agriculture [564], where atmospheric warming leads to the amplification of precipitation extremes [198,565], as seen in trends in research on global climate change [566], in changing climate inducing time-varying extreme rainfall intensity-duration-frequency curves [567]. Also in China as Minjiang River annual and seasonal precipitation variation [568], in annual and daily extreme precipitation distribution trends over 1960-2010 in urban areas [569], in changes in precipitation patterns over Beijing over 1960-2012 (which is a 21.54 million 'thermal island') [570], annual/seasonal precipitation variation in a mountain area [571], in Serbia as annual and seasonal variability of precipitation in Vojvodina [572], 1961-1990 mapping of annual precipitation [573], in the impact of climatic factors on maize yields [574]. Further, in Iran as in 1950-2000 rainfall trends [575], using 1950-2000 spatial and temporal variability of precipitation [576], annual and seasonal distribution pattern of rainfall including neighbouring regions [577], in India as in trends in the rainfall pattern over the whole country [578], uneven distributions overturn benefits of higher precipitation for crop yields [579], changes in rainfall seasonality pattern over the whole country [580], in Africa in 19th through the 21st century rainfall over the continent [581], and in Mexico as in disruptions in the timing and intensity of precipitation in Calakmul [582]. This will extend to highly populated centres in one form or another, e.g., in the U.S. such as in quantification of changes in future intensity-duration-frequency curves [583]. Uneven precipitation, such as the one projected in India, in terms of fluctua- 
tions in water flows and changing monsoon patterns, leading to blue water waste due to low levels of water storage capacity per capita [584].

\subsection{Climate Uncertainty}

Climate is defined in terms of the physics of its change and variability as "a forced, dissipative, chaotic system that is out of equilibrium and whose complex natural variability arises from the interplay of positive and negative feedbacks, instabilities and saturation mechanisms" [585]. Climate change and variability uncertainty is a subject which has not been attributed sufficient importance [586] in applicative studies and this uncertainty is directly related to existing [587] hydrological uncertainty [588], such as in impacts on the hydrological cycle over France with uncertainties taken into consideration [589] and has a direct impact on water resources [590]. Those uncertainties are associated with internal climate system variability and the hydrologic modelling itself [591], while climate forcing uncertainty impacts on the variations of global and continental water balance components [592] extending even into environmental flows e.g., for the Mekong River [593]. They are of great importance as the existence and size of uncertainty, distinguished into uncertainty due to lack of knowledge regarding the changes and uncertainty due to variability [594], which is critically associated with risk assessments connected to instrumental economic variables to which physical uncertainties must be transmitted in some way and therefore their detailed and credible knowledge will enable at first instance to imbed some flexibility in water infrastructure programs [595]. One opinion is that this transmission can be manifested by changing decision rules and evaluation principles used for water infrastructure project justification so that they are compatible with climate uncertainty [596]. However, climate uncertainly, along with all other main variables, is incorporated into wider scenarios with distinctly different impacts, which are deterministically manifested during lengthy periods, a fact that more or less precludes decision-making regarding proactive long-term projects. Perhaps a promising approach is dynamic adaptive policy pathways (DAPP) [597].

There are methods leading to the separation of deterministic and probabilistic components of main variables [598] e.g., in the case of precipitation [599], in hydrologic time series [600] and in general e.g., in the case of time series [601,602] but, in separate models, they do not match the success of a hybrid model [602]. It should be noted that these methods separate uncertainty from determinism, but they do not cause any reduction to it.

Added to the above is the case of for climate applicable [586,603-605] Knightian uncertainties, "true uncertainties" indetectable under hindsight which are not reducible to an "objective, quantitatively determined probability" [606] (p. 321). These are manifestly transmitted through to any economic assessment process, in addition to entropic preferences [607], leading to the adoption of one-parameter Atkinson preference functions [608] which may be problematic to the classic style Georgescu-Roegen entropy, linking climate to economy [609].

\subsection{Country Scale More Pertinent Than Global}

At a global scale, resource economics is considered to be a thermodynamically closed system where entropy increases or energy degrades $[609,610]$ and so is the hydrological cycle [611,612]. As seen in Section 3.5.2 3990 billion cubic meters of water were consumed globally in 2014, a quantity which approaches the lower limit of the 4000-6000 billion cubic $\mathrm{m}$ /year danger zone according to the planetary boundaries framework [613]. However, this picture, taking into consideration that world population in 2014 was 7.2 billion [614], yields an average per capita consumption correspondence which would have meaning if population distribution and the subjects addressed in Section 4.2, Section 4.3, Section 4.4, Section 4.5 were equitably distributed, which is not the case.

Renewable freshwater resources per capita differ according to regions as can be seen in Figure 11. 


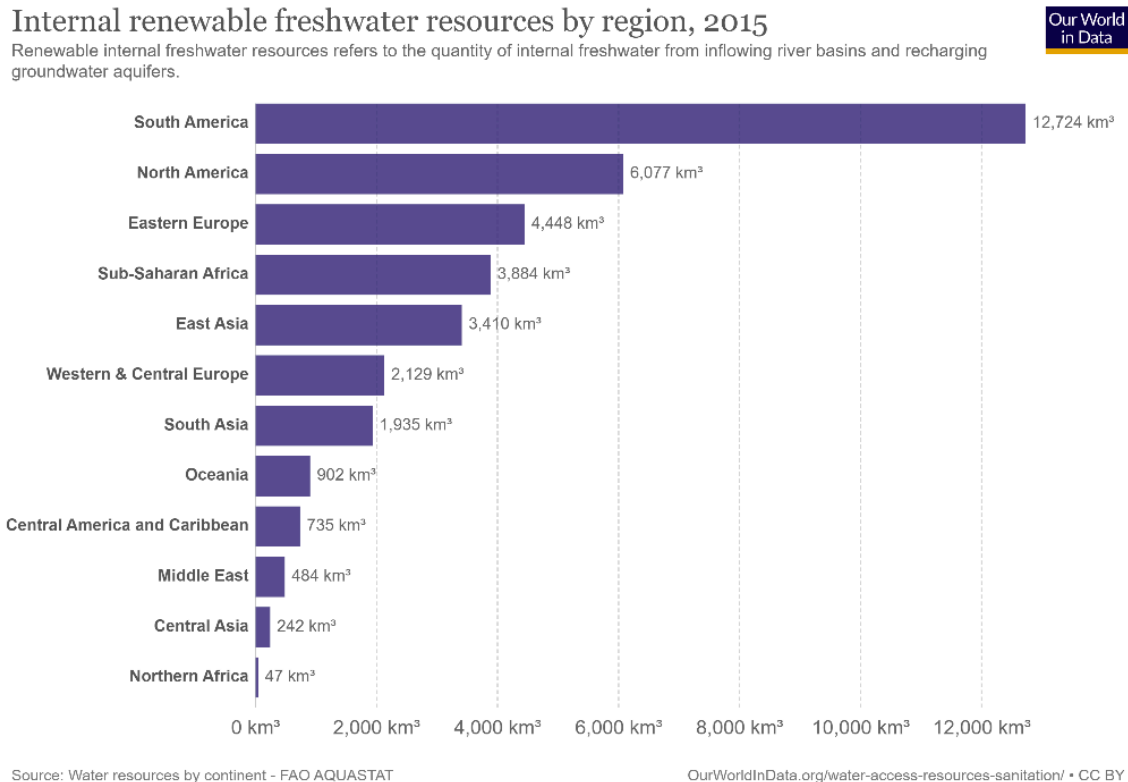

Figure 11. Renewable freshwater per region 2015 (modified from [615]).

On the other hand, both resource economics, dictated by the sovereign state's economic policy, and the hydrological cycle are open systems at country level and consequently the degrees of water scarcity differ as well. In this case, as can be seen at country level in Figure 19 below, the notion of relative scarcity pioneered by Faber [616], defined in terms of quantity over available water resources as "a good is scarce in relation to other scarce goods" [617], plays a role which cannot manifest itself in a credible way at a global scale due to inequitable availability of resources. In the case of transnationally shared resources a case study of the Aral Sea [618] shows equal probability of conflict and cooperation, a matter not taken into account at global scale statistics and as a general problem it is still in the phase of suggesting a viable solution [619-621].

The summary legal construct of international treaties and U.N. decisions regarding the prevention of water scarcity have no "teeth" as transgressor countries are not penalized in any meaningful way while supervision has only a fact-finding mandate. In reality there is no global organization with the power to enforce any of the above and assume responsibility for the results of these decisions which in essence means that in the applicative phase in the immortal words of U.K. Supreme Court Judge Thurlow, " ... has no soul to be damned and no body to be kicked" just like a corporation [622] hold true.

Increased population and low GDP lead to a tipping point, regardless of perceived estimation water resources being ample [623] while conversely the water footprint expands with higher GDP [624]. The point of view where microscale precedes mesoscale is also supported by Falkenmark [77]. A list of country rankings regarding water risk is found at Aqueduct [625].

In Figure 12 it is shown that most countries belonging to the set with available data are in states ranging from low-to-medium stress to extremely high stress.

At the country level, in the common case of a water market subject to "institutional arrangements", we enter into the realm of state economic policy where restrictions are imposed while the central government budget might cover, at least in part, the reallocation cost as the economy will suffer from the trade deficit incurred by virtual water imports, as seen in an 160 country study over the period 1982-2007, where drought events increase net global virtual water flows by $5 \times 10^{9} \mathrm{~m}^{3} \mathrm{yr}^{-1}$ to $6.34 \times 10^{9} \mathrm{~m}^{3} \mathrm{yr}^{-1}$ while each additional square kilometer of agricultural land area reduces net virtual water import by 10,620 to $18,419 \mathrm{~m}^{3}$ [626], a 2010 estimate leads to that international trade reduces global water use in agriculture by $5 \%$ [627], while in some Mediterranean countries, a reduction of $1 \%$ of agricultural productivity corresponds to imports of 233 million cubic meters of virtual 
water [628]. However, virtual water import/export balance may not correspond to water scarcity only, case in point being the grain import-export balance in Spain in the 1997-2005 period [629], a country whose south-eastern part is semi-arid [630] and water scarcity appears every 5-6 years [631]. Quite importantly, virtual water introduces a hitherto unknown and hence Knightian type variable [606], the "virtual water cycle" variable [632]. All these quantifiable additions on instrumental economic variables would pass unseen at a position over country level.

Freshwater withdrawals as a share of internal resources, 2014

Annual freshwater withdrawals refer to total water withdrawals from agriculture, industry and municipal/domestic uses. Withdrawals can exceed $100 \%$ of total renewable resources where extraction from nonrenewable aquifers or desalination plants is considerable.

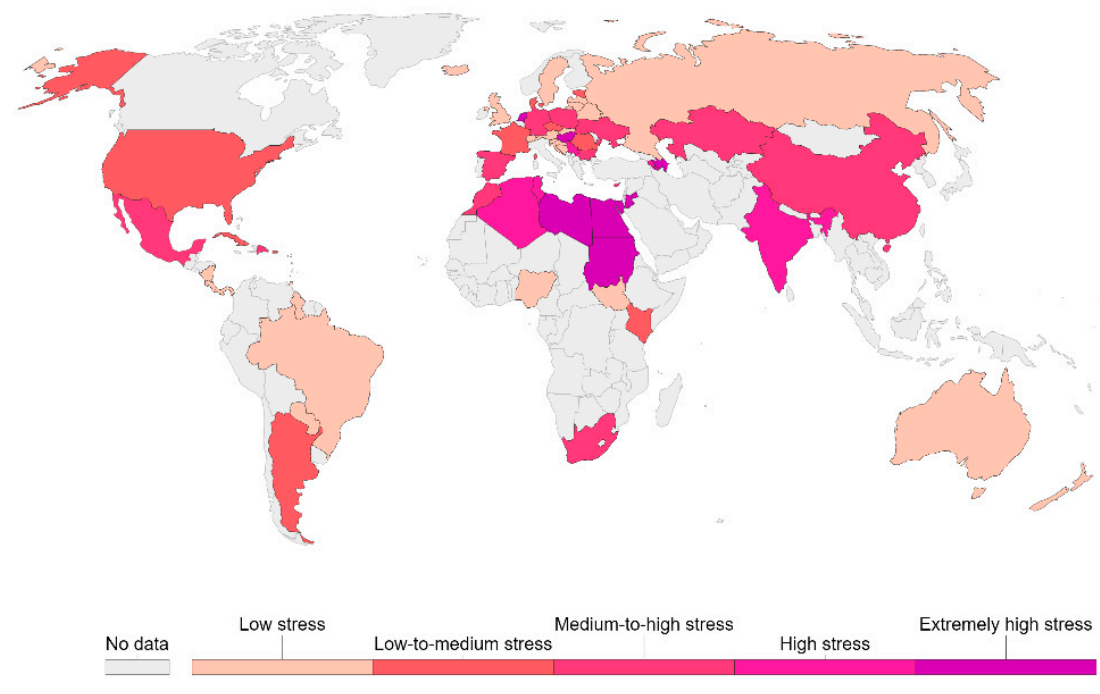

Figure 12. Freshwater withdrawals as a share of internal resources (modified from [615]).

Thus, the country-by-country depiction which shows anisotropy allows for direct economic assessment in the spirit described in the Methodology section while the global statistical picture does not.

\section{Conclusions}

The objective of this paper was analysed in seven stages, using a substantial number of references which enabled the decomposition of general and theoretical definitions and physical variables into their economically important facets, which were firmly anchored temporally, spatially, and in terms of scale, through the use of a large number of referenced incidents. Particular care was demonstrated in focusing on present and future problems stemming either from external conditions or from the internal structures of the theories which must be carried over to a faithful economic assessment of the scarcity phenomenon.

Difficulties emerge in the matter of associating physical blue and green water scarcity to the instrumental variables causing it. The first is the set of definitions describing the physical phenomenon of scarcity which was analysed in this paper. The definitions are too broad to be meaningfully carried over to a realistic economic model and the lack of distinction between "want" and "need" causes problems of economic interpretation. The second one is that these variables are interdependent to some degree via the physical theory of which they are part without a clear formal and theoretical quantitative and qualitive analysis of this interdependence, which causes problems in the economic depiction of scarcity in a process of economic reverse engineering seeking causal connection i.e., the case where one seeks to depict in economic terms any form of relational correspondence between a set of scarcity causing variables in the process of triggering scarcity and scarcity itself. This difficulty is quite important as it presents impediments to any economic theory 
from going down to the basic platform underlying this type of scarcity and linking global variables to scaled down instances in a seamless unified form as scaling down introduces new variables which operate at the particular level of scale and have no global existence, which perhaps has a solution by assuming the existence of a set of variables which at global level may appear as noise or Knightian variables but as downscaling occurs they acquire a concrete form allowing for a hybrid deterministic/uncertainty depiction. The third is the fact that country level climate uncertainty or causality has no clear picture which impedes correspondence between physical and economic uncertainly, the latter leading to economic risk, which was analysed extensively in this paper.

From the physical point of view the emerging picture is bleak but then the incident instances reported and the interrelationship of the main variables are commensurate with this point of view, and if one digs deeper there is a chain of too many beneficial constraints assumed to be viable with a high degree of certainty and as many uncertainties not taken into consideration.

However, by assuming the country level water scarcity to be the dominant building block more targeted measurements at country level leading to a structured component picture at regional level will allow for statistical analysis, including maximum application of causality tests, which will clarify the empirical interdependence of physical scarcity causing variables and allow for establishing a clear-cut correspondence with economic instrumental variables.

\section{Future Work}

The next steps are the examination of economic scarcity in the way adopted in this paper and an economic model which ties both physical and economic scarcity with the main instrumental variables of a national economy.

Author Contributions: Conceptualization, K.Z. and D.P.; methodology, K.Z. and D.P.; validation, K.Z. and D.P.; formal analysis, K.Z. and D.P.; investigation, K.Z. and D.P.; resources, K.Z. and D.P.; data curation, K.Z. and D.P.; writing-original draft preparation, K.Z. and D.P.; writing-review and editing, K.Z. and D.P.; visualization, K.Z. and D.P.; supervision, D.P.; All authors have read and agreed to the published version of the manuscript.

Funding: This research received no external funding.

Institutional Review Board Statement: Not applicable.

Informed Consent Statement: Not applicable.

Data Availability Statement: Data sharing not applicable.

Conflicts of Interest: The authors declare no conflict of interest.

\section{References}

1. ICWE. The Dublin Statement on Water and Sustainable Development. In Proceedings of the ICWE (International Conference on Water and the Environment), Dublin, Ireland, 26-31 January 1992; p. 55.

2. U.N. Report of the United Nations Conference on Environment and Development. In Proceedings of the United Nations Conference on Environment and Development, Rio de Janeiro, Brazil, 3-14 June 1992; Volume 1, p. 492.

3. Mauss, M. Essai sur le don. Forme et raison de l'échange dans les sociétés archaïques. In Sociologie et Anthropologie; Mauss, M., Ed.; Quadrige/Presses Universitaires de France: Paris, France, 1950; pp. 145-279.

4. Schellens, M.K.; Gisladottir, J. Critical natural resources: Challenging the current discourse and proposal for a holistic definition. Resources 2018, 7, 79. [CrossRef]

5. Mancini, L.; Benini, L.; Sala, S. Characterization of raw materials based on supply risk indicators for Europe. Int. J. Life Cycle Assess. 2018, 23, 726-738. [CrossRef]

6. PBL. The Geography of Future Water Challenges; Dutch Government: The Hague, The Netherlands, 2018.

7. World Economic Forum. Global Risks 2015, 10th ed.; World Economic Forum: Geneva, Switzerland, 2015.

8. Veldkamp, T.I.E.; Wada, Y.; Aerts, J.C.J.H.; Ward, P.J. Towards a global water scarcity risk assessment framework: Incorporation of probability distributions and hydro-climatic variability. Environ. Res. Lett. 2016, 11, 024006. [CrossRef]

9. Orr, S.; Cartwright, A.; Tickner, D. Understanding Water Risks; WWF: Gland, Switzerland, 2009.

10. Hillel, D. Out of the Earth: Civilization and the Life of the Soil; University of California Press: Berkeley, CA, USA, 1992. 
11. Wrathall, D.J.; Van Den Hoek, J.; Walters, A.; Devenish, A. Water Stress and Human Migration: A Global, Georeferenced Review of Empirical Research; FAO: Rome, Italy, 2018.

12. Nagabhatla, N.; Pouramin, P.; Brahmbhatt, R.; Fioret, C.; Glickman, T.; Newbold, K.B.; Smakhtin, V. Water and Migration: A Global Overview; United Nations University, Institute for Environmrnt, Water and Health: Hamilton, ON, Canada, 2020.

13. Reisner, M. Cadillac Desert: The American West and Its Disappearing Water; Penguin Books: New York, NY, USA, 1993.

14. Falkenmark, M. Meeting water requirements of an expanding world population. Philos. Trans. R. Soc. B Biol. Sci. 1997, 352, 929-936. [CrossRef]

15. Portmann, F.T.; Döll, P.; Eisner, S.; Flörke, M. Impact of climate change on renewable groundwater resources: Assessing the benefits of avoided greenhouse gas emissions using selected CMIP5 climate projections. Environ. Res. Lett. 2013, 8, 024023. [CrossRef]

16. Jiménez Cisneros, B.E.; Oki, T.; Arnell, N.W.; Benito, G.; Cogley, J.G.; Döll, P.; Jiang, T.; Mwakalila, S.S. "Freshwater resources," in Climate Change 2014: Impacts, Adaptation, and Vulnerability. Part A: Global and Sectoral Aspects. Contribution of Working Group II to the Fifth Assessment Report of the Intergovernmental Panel on Climate Change; Field, C.B., Barros, V.R., Dokken, D.J., Mach, K.J., Mastrandrea, M.D., Bilir, T.E., Chatterjee, M., Ebi, K.L., Estrada, Y.O., Genova, R.C., et al., Eds.; Cambridge University Press: Cambridge, UK, 2014; pp. 229-269.

17. Garrick, D.E.; Hanemann, M.; Hepburn, C. Rethinking the economics of water: An assessment. Oxf. Rev. Econ. Policy 2020, 36, 1-23. [CrossRef]

18. Seckler, D.; Amarasinghe, U.; Molden, D.; de Silva, R.; Barker, R. World Water Demand And Supply, 1990 to 2025 : Scenarios and Issues; In-ternational Irrigation Management Institute (IIMI): Colombo, Sri Lanka, 1998.

19. Postel, S.L. Water and world population growth. Am. Water Work. Assoc. 2000, 92, 131-138. [CrossRef]

20. Falkenmark, M. Growing water scarcity in agriculture: Future challenge to global water security. Philos. Trans. R. Soc. A Math. Phys. Eng. Sci. 2013, 371, 20120410. [CrossRef] [PubMed]

21. Ma, T.; Sun, S.; Fu, G.; Hall, J.W.; Ni, Y.; He, L.; Yi, J.; Zhao, N.; Du, Y.; Pei, T.; et al. Pollution exacerbates China's water scarcity and its regional inequality. Nat. Commun. 2020, 11, 1-9. [CrossRef]

22. Walker, G. Water scarcity in England and Wales as a failure of (meta) governance. Water Altern. 2014, 7, $388-413$.

23. Partain, R.A. UCLA Journal of Environmental Law and Policy Is a Green Paradox Spectre Haunting International Climate Change Laws and Conventions? UCLA J. Environ. Law Policy 2015, 33, 62-131.

24. Chakkaravarthy, D.N.; Balakrishnan, T. Water Scarcity- Challenging the Future. Int. J. Agric. Environ. Biotechnol. 2019, 12, 1-9. [CrossRef]

25. Kaushal, S.S.; Gold, A.J.; Mayer, P.M. Land use, climate, and water resources-global stages of interaction. Water 2017, $9,815$. [CrossRef] [PubMed]

26. Rijsberman, F.R. Water scarcity: Fact or fiction? Agric. Water Manag. 2006, 80, 5-22. [CrossRef]

27. Morrison, J.; Morikawa, M.; Murphy, M.; Schulte, P. Water Scarcity E Climate Change: Growing Risks for Businesses and Investors; Pacific Institute: Oakland, CA, USA, 2009.

28. FAO. Understanding Water Scarcity FAO. 2020. Physical Water Scarcity Occurs When Water to Meet All Demands. Economic Water Scarcity Is Caused, Places where Water Is Abundant. Available online: http://www.fao.org/resources/infographics/ infographics-details/en/c/218939/\# (accessed on 21 February 2021).

29. Alcamo, J.M.; Vörösmarty, C.J.; Naiman, R.J.; Lettenmaier, D.P.; Pahl-Wostl, C. A grand challenge for freshwater research: Understanding the global water system. Environ. Res. Lett. 2008, 3, 010202. [CrossRef]

30. Ahopelto, L.; Veijalainen, N.; Guillaume, J.; Keskinen, M.; Marttunen, M.; Varis, O. Can There be Water Scarcity with Abundance of Water? Analyzing Water Stress during a Severe Drought in Finland. Sustainability 2019, 11, 1548. [CrossRef]

31. Nairizi, S. (Ed.) Irrigated Agriculture Development under Drought and Water Scarcity. 2017. Available online: https://www.icid. org/drought_pub2017.pdf (accessed on 21 February 2021).

32. Seckler, D.; Barker, R.; Amarasinghe, U. Water scarcity in the twenty-first century. Int. J. Water Resour. Dev. 1999, 15, $29-42$. [CrossRef]

33. Molden, D. Water for Food, Water for Life: A Comprehensive Assessment of Water Management in Agriculture; Earthscan/International Water Management Institute: London, UK, 2007.

34. Comprehensive Management in Agriculture, FAO: Land and Water 2007. Available online: http://www.fao.org/land-water/ resources/graphs-and-maps/en/ (accessed on 21 February 2021).

35. Jury, W.A.; Vaux, H. The role ofscience in solving the world's emerging water problems. Proc. Natl. Acad. Sci. USA 2005, 102, 15715-15720. [CrossRef]

36. Salameh, E. Water Shortages and Environmental Degradation. In Living with Water Scarcity; Baban, J.M.J., Al-Ansani, N.A., Eds.; Al al-Bayt University Publications: Mafraq, Jordan, 2001; pp. 1-17.

37. Freeze, A.R.; Cherry, J.A. Groundwater; Prentice-Hall, Inc.: Hoboken, NJ, USA, 1979; Volume 5.

38. USGS. What Is Groundwater? USGS: Reston, Virginia, 2019.

39. Watkins, K. Human Development Report 2005-2006 beyond Scarcity: Power, Poverty and the Global Water Crisis; Palgrave Mac-Millan: London, UK, 2006. 
40. Elliott, J.; Deryng, D.; Müller, C.; Frieler, K.; Konzmann, M.; Gerten, D.; Glotter, M.; Flörke, M.; Wada, Y.; Best, N. Constraints and po-tentials of future irrigation water availability on agricultural production under climate change. Proc. Natl. Acad. Sci. USA 2014, 111, 3239-3244. [CrossRef]

41. Water Scarcity Drafting Group. Water Scarcity Management in the Context of WFD 2006; Water Scarcity Drafting Group: Brussels, Belgium, 2006.

42. Brown, A.; Matlock, M.D. A Review of Water Scarcity Indices and Methodologies; The Sustainability Consortium: Scottsdale, Arizona, 2011; p. 106.

43. Liu, J.; Hong, J.; Gosling, S.; Kummu, M.; Flörke, M.; Pfister, S.; Hanasaki, N.; Wada, Y.; Zhang, X.; Zheng, C.; et al. Water scarcity assessments in the past, present, and future. Earth's Future 2017, 5, 545-559. [CrossRef]

44. Muller, M. Water accounting, corporate sustainability and the public interest. In Water Accounting International Approaches to Policy and Decision-Making, 1st ed.; Monograph Book; Godfrey, J.M., Chalmers, K., Eds.; Edward Elgar Publishing: Cheltenham, UK, 2012; pp. 203-220.

45. Wada, Y.; Bierkens, M.F.P. Sustainability of global water use: Past reconstruction and future projections. Environ. Res. Lett. 2014, 9, 104003. [CrossRef]

46. Sood, A.; Prathapar, S.; Smakhtin, V. Green and Blue Water. In Key Concepts in Water Resource Management: A Review and Critical Evaluation; Lautze, J., Ed.; Routledge: London, UK, 2014.

47. Lazarovitch, N.; Vanderborght, J.; Jin, Y. The Root Zone: Soil Physics and Beyond. Vadose Zone J. 2018, 17, 1-7. [CrossRef]

48. Falkenmark, M. Land-water linkages: A synopsis. Land and Water Integration and River Basin Management. FAO Land Water Bull. 1995, 1, 15-16.

49. Falkenmark, M.; Rockström, J. The new blue and green water paradigm: Breaking new ground for water resources planning and management. J. Water Resour. Plan. Manag. 2006, 132, 129-132. [CrossRef]

50. Mohtar, R.H.; Assi, A.T.; Daher, B.T. Bridging the Water and Food Gap: The Role of the Water-Energy-Food Nexus. Unu-Flores 2015, 5, 1-31.

51. Wu, H.T. Research on Assessment and Management of Green Water. China Popul. Resour. Environ. 2008, $18,61-67$.

52. Falkenmark, M.; Rockstrom, J. Balancing Water for Humans and Nature: The New Approach in Ecohydrology; Routledge: London, UK, 2004.

53. Gleick, P.H. Water use. Annu. Rev. Environ. Resour. 2003, 28, 275-314. [CrossRef]

54. Shiklomanov, I.A. World fresh water resources. In Water in Crisis: A Guide to the World's Fresh Water Resources; Gleick, P.H., Ed.; Oxford University Press: New York, NY, USA, 1993; pp. 13-24.

55. Rockström, J.; Falkenmark, M.; Karlberg, L.; Hoff, H.; Rost, S.; Gerten, D. Future water availability for global food production: The potential of green water for increasing resilience to global change. Water Resour. Res. 2009, 45, 1-16. [CrossRef]

56. Halstead, M.; Kober, T.; Zwaan, B.C.C. Understanding the Energy-Water Nexus; Energy Research Centre of The Netherlands: Petten, The Netherlands, 2014.

57. Munia, H.; Guillaume, J.H.A.; Mirumachi, N.; Porkka, M.; Wada, Y.; Kummu, M. Water stress in global transboundary river basins: Significance of upstream water use on downstream stress. Environ. Res. Lett. 2016, 11, 014002. [CrossRef]

58. Rosa, L.; Chiarelli, D.D.; Rulli, M.C.; Dell'Angelo, J.; D’Odorico, P. Global agricultural economic water scarcity. Sci. Adv. 2020, 6, 1-11. [CrossRef]

59. Gerten, D.; Hoff, H.; Bondeau, A.; Lucht, W.; Smith, P.; Zaehle, S. Contemporary 'green' water flows: Simulations with a dynamic global vegetation and water balance model. Phys. Chem. Earth Parts A B C 2005, 30, 334-338. [CrossRef]

60. Rost, S.; Gerten, D.; Bondeau, A.; Lucht, W.; Rohwer, J.; Schaphoff, S. Agricultural green and blue water consumption and its influence on the global water system. Water Resour. Res. 2008, 44, 1-17. [CrossRef]

61. Postel, S.L. Entering an Era of Water Scarcity: The Challenges Ahead. Ecol. Appl. 2000, 10, 941-948. [CrossRef]

62. OECD. Thematic Working Group 1: Stakeholder Engagement for Effective Water Governance; OECD: Paris, France, 2014.

63. Freeman, R.E. Strategic Approach-A Stakeholder Approach; Pittman Publishing: London, UK, 1984.

64. Newcombe, R. From client to project stakeholders: A stakeholder mapping approach. A Festschrift for Professor Syd Urry. Constr. Manag. Econ. 2003, 21, 841-848, 1925-1999. [CrossRef]

65. Cleland, D.I.; Ireland, L.R. Project Management Strategic Design and Implementation, 4th ed.; McGraw Hill: New York, NY, USA, 2002.

66. Howe, C.W. The Effects of Water Resource Development on Economic Growth: The Conditions for Success. Nat. Resour. J. 1976, $16,939-955$.

67. AQUASTAT. Water Use: Thematic Structure FAO's Global Information System on Water and Agriculture. Available online: http:/ / www.fao.org/aquastat/en/overview/methodology/water-use (accessed on 22 February 2021).

68. Ritchie, H.; Roser, M. Water Use and Stress, Our World in Data. Available online: https:/ / ourworldindata.org/water-use-stress (accessed on 22 February 2021).

69. Feige, E.L.; Blau, D.M. The Economics of Natural Resource Scarcity and Implications for Development Policy and International Cooperation. In Resources and Development: Natural Resource Polices and Economic Development in an Interdependent World; Dorner, P., El-Shafie, M.A., Eds.; University of Wisconsin Press: Madison, WI, USA, 1980.

70. Winpenny, J.T. Managing Water Scarcity for Water Security; FAO: Rome, Italy, 1997. 
71. Applegreen, B. Appendix 3: Keynote paper-Management of water scarcity: National water policy reform in relation to regional development cooperation. In Proceedings of the First FAO E-Mail Conference on Managing Water Scarcity, Rome, Italy, 4 March-9 April 1997.

72. U.N. Water, a Shared Responsibility: The United Nations World Water Development Report 2 (WWDR 2); U.N.: New York, NY, USA, 2007

73. FAO. Coping with Water Scarcity an Action Framework for Agriculture and Food Security; FAO: Rome, Italy, 2012.

74. FAO. Review of World Water Resources by Country; FAO: Rome, Italy, 2003.

75. Xu, H.; Wu, M. Water Availability Indices-A Literature Review; Technical Report; Argonne National Laboratory: Illinois, IL, USA, 2017.

76. Cosgrove, P. Water for Growth and Security. In Water Crisis: Myth or Reality? Marcelino Botin Water Forum 2004; Taylor \& Francis: Leyden, The Netherlands, 2006; pp. 37-42.

77. Falkenmark, M.; Lundqvist, J.; Widstrand, C. Macro-scale water scarcity requires micro-scale approaches: Aspects of vulnerability in semi-arid development. Nat. Resour. Forum 1989, 13, 258-267. [CrossRef]

78. The Commission to the European Parliament and the Council Eur. Comm. DG Environ., Addressing the Challenge of Water Scarcity and Droughts in the European Union; EU: Brussels, Belgium, 2007; p. 14.

79. Postel, S. Pillar of Sand: Can the Irrigation Miracle Last? W. W. Norton \& Company: New York, NY, USA, 1999.

80. Bruinsma, J. The resource outlook to 2050: By how much do land, water and crop yields need to increase by 2050? In Expert Meeting on How to Feed the World in 2050 Food and Agriculture Organization of the United Nations Economic and Social Development Department; FAO: Rome, Italy, 2009; pp. 24-26.

81. Hoff, H.; Falkenmark, M.; Gerten, D.; Gordon, L.; Karlberg, L.; Rockström, J. Greening the global water system. J. Hydrol. 2010, 384, 177-186. [CrossRef]

82. Bhat, T.A. An Analysis of Demand and Supply of Water in India. J. Environ. Earth Sci. 2014, 4, 67-73.

83. Abhay, R.K. Measurement of Water Scarcity. In Spatial Diversity and Dynamics in Resources and Urban Development Volume 1: Regional Resources; Dutt, A.K., Noble, A.G., Costa, F.J., Thakur, S.K., Thakur, R.R., Sharma, H.S., Eds.; Springer: Berlin/Heidelberg, Germany, 2015; pp. 277-296.

84. LMehta, L.; Marshall, S.; Movik, S.; Stirling, A.; Shah, E.; Smith, A.; Thompson, J. Liquid Dynamics: Challenges for Sustainability in Water and Sanitation; STEPS Centre: Brighton, UK, 2007; p. 6.

85. Keller, A.; Sakthivadivel, R.; Seckler, D. Water Scarcity and the Role of Storage in Development; International Water Management Institute: Colombo, Sri Lanka, 2000.

86. Damkjaer, S.; Taylor, R. The measurement of water scarcity: Defining a meaningful indicator. Ambio 2017, 46, 513-531. [CrossRef]

87. Hussain, F.; Khoso, S. Water Shortage; Its Causes, Impacts and Remedial Measures. In Proceedings of the 6th International Civil Engineering Congress, Karachi, Pakistan, 28 December 2013; pp. 1-6.

88. Molden, D.; Oweis, T.Y.; Pasquale, S.; Kijne, J.W.; Hanjra, M.A.; Bindraban, P.S.; Bouman, B.A.M.; Cook, S.; Erenstein, O.; Farahani, H. et al. Pathways for increasing agricultural water productivity. In Water for Food, Water for Life. A Comprehensive Assessment of Water Management in Agriculture; Molden, D., Ed.; Earthscan-International Water Management Institute: London, UK, 2007; pp. 279-310.

89. Hoekstra, A.Y.; Mekonnen, M.M. The water footprint of humanity. Proc. Natl. Acad. Sci. USA 2012, 109, 3232-3237. [CrossRef]

90. Ramankutty, N.; Evan, A.T.; Monfreda, C.; Foley, J.A. Farming the planet: 1. Geographic distribution of global agricultural lands in the year 2000. Glob. Biogeochem. Cycles 2008, 22, 1-19. [CrossRef]

91. Zhongwei, H.; Hejazi, M.; Tang, Q.; Vernon, C.; Liu, Y.; Chen, M.; Calvin, K. Global agricultural green and blue water consumption under future climate and land use changes. J. Hydrol. 2019, 574, 242-256.

92. Steduto, P.; Hsiao, T.C.; Fereres, E.; Raes, D. Crop Yield Response to Water; FAO: Rome, Italy, 2012; p. 66.

93. Goldewijk, K.K.; Beusen, A.; van Drecht, G.; de Vos, M. The HYDE 3. 1 spatially explicit database of human-induced global land-use change over the past 12,000 years. Glob. Ecol. Biogeogr. 2010, 20, 73-86. [CrossRef]

94. World Bank. Agricultural Land, Total 2015. Available online: https:/ / data.worldbank.org/indicator/AG.LND.AGRI.K2 (accessed on 21 April 2021).

95. Allan, J.A. Policy responses to the closure of water resources: Regional and global issues in Water policy: Allocation and management in practice. In Proceedings of the International Conference, Bedford, UK, 23-24 September 1996; p. 384.

96. Aldaya, M.M.; Hoekstra, A.Y.; Allan, J.A. Strategic Importance of Green Water in iinterntational Crop Trade; UNESCO-IHE: Delft, The Netherlands, 2008.

97. Leamer, E.E. The Heckscher-Ohlin Model in Theory and Practice; Princeton Study No 77; Princeton University: Princeton, NJ, USA, 1995.

98. Postel, S. Dividing the Waters: Food Security, Ecosystem Health, and the New Politics of Scarcity; Worldwatch Institute: Washington, DC, USA, 1996; p. 132

99. Gleick, P.H. Global Freshwater Resources: Soft-Path Solutions for the 21st Century. Science 2003, 302, 1524-1528. [CrossRef]

100. Rijsberman, F. Troubled water, water troubles: Overcoming an important constraint to food security. In Proceedings of the Sustainable Food Security for All by 2020, An International Conference, Bonn, Germany, 4-6 September 2001; pp. 141-144.

101. Lenzen, M.; Moran, D.; Bhaduri, A.; Kanemoto, K.; Bekchanov, M.; Geschke, A.; Foran, B. International trade of scarce water. Ecol. Econ. 2013, 94, 78-85. [CrossRef] 
102. Porkka, M.; Gerten, D.; Schaphoff, S.; Siebert, S.; Kummu, M. Causes and trends of water scarcity in food production. Environ. Res. Lett. 2016, 11, 015001. [CrossRef]

103. Kummu, M.; Guillaume, J.H.A.; De Moel, H.; Eisner, S.; Flörke, M.; Porkka, M.; Siebert, S.; Veldkamp, T.I.E.; Ward, P.J. The world's road to water scarcity: Shortage and stress in the 20th century and pathways towards sustainability. Sci. Rep. 2016, 6, 38495. [CrossRef] [PubMed]

104. J. Rockström, J.; Falkenmark, M.; Allan, T.; Folke, C.; Gordon, L.; Jägerskog, A.; Kummu, M.;Lannerstad, M.; Meybeck, M.; Molden, D. et al. The Unfolding Water Drama in the Anthropocene: Towards a resilience based perspective on water for global sustainability. J. Hydrol. Eng. 2014, 7, 1249-1261.

105. Oeurng, C.; Cochrane, T.A.; Chung, S.; Kondolf, M.G.; Piman, T.; Arias, M.E. Assessing climate change impacts on river flows in the Tonle Sap Lake Basin, Cambodia. Water 2019, 11, 618. [CrossRef]

106. McCabe, G.J.; Wolock, D.M.; Pederson, G.T.; Woodhouse, C.A.; McAfee, S. Evidence that recent warming is reducing upper Colorado river flows. Earth Interact. 2017, 21, 1-14. [CrossRef]

107. Schewe, J.; Heinke, J.; Gerten, D.; Haddeland, I.; Arnell, N.; Clark, D.; Dankers, R.; Eisner, S.; Fekete, B.; Colón-González, F.; et al Mul-timodel assessment of water scarcity under climate change. Proc. Natl. Acad. Sci. USA 2014, 111, 3245-3250. [CrossRef]

108. Huang, H.; Han, Y.; Jia, D. Impact of climate change on the blue water footprint of agriculture on a regional scale. Water Sci. Technol. Water Supply 2019, 19, 52-59. [CrossRef]

109. BIO Intelligence Service. Literature Review On The Potential Climate Change Effects on Drinking Water Resources Across the Eu and the Identification of Priorities Among Different Types of Drinking Water Supplies; BIO Intelligence Service: Paris, France, 2012.

110. Raskin, P.; Gleick, P.; Kirshen, P.; Pontius, G.; Strzepek, K. Water Futures: Assessment of Long-Range Patterns and Problems Stockholm; Stockholm Environment Institute: Stockholm, Sweden, 1997.

111. Mekonnen, M.M.; Hoekstra, A.Y. Four billion people facing severe water scarcity. Sci. Adv. 2016, 2, 1-7. [CrossRef] [PubMed]

112. Falkenmark, M. The Massive Water Scarcity Now Threatening Africa: Why Isn't It Being Addressed? Ambio 1989, 18, 112-118.

113. Scholes, R. Global Terrestrial Observing System: Regional Implementation Plan for Southern Africa; FAO: Rome; Italy, 2001.

114. Rockstrom, J.; Lannerstad, M.; Falkenmark, M. Assessing the water challenge of a new green revolution in developing countries. Proc. Natl. Acad. Sci. USA 2007, 104, 6253-6260. [CrossRef] [PubMed]

115. Rockström, J.; Barron, J.; Fox, P. Water productivity in rain-fed agriculture: Challenges and opportunities for smallholder farmers in drought-prone tropical agroecosystems. In Water Productivity in Agriculture: Limits and Opportunities for Improvement; International Water Management Institute: Colombo, Sri Lanka, 2009; pp. 145-162.

116. Bogardi, J.J.; Fekete, B.M.; Vörösmarty, C.J. Planetary boundaries revisited: A view through the 'water lens'. Curr. Opin. Environ. Sustain. 2013, 5, 581-589. [CrossRef]

117. Dearing, J.A.; Wang, R.; Zhang, K.; Dyke, J.G.; Haberl, H.; Hossain, S.; Langdon, P.G.; Lenton, T.M.; Raworth, K.; Brown, S.; et al. Safe and just operating spaces for regional social-ecological systems. Glob. Environ. Chang. 2014, 28, 227-238. [CrossRef]

118. Nash, K.L.; Cvitanovic, C.; Fulton, E.A.; Halpern, B.S.; Milner-Gulland, E.J.; Watson, R.A.; Blanchard, J.L. Planetary boundaries for a blue planet. Nat. Ecol. Evol. 2017, 1, 1625-1634. [CrossRef]

119. Häyhä, T.; Lucas, P.L.; van Vuuren, D.P.; Cornell, S.E.; Hoff, H. From Planetary Boundaries to national fair shares of the global safe operating space-How can the scales be bridged? Glob. Environ. Chang. 2016, 40, 60-72. [CrossRef]

120. Steffen, W.; Persson, Å.; Deutsch, L.; Zalasiewicz, J.; Williams, M.; Richardson, K.; Crumley, C.; Crutzen, P.; Folke, C.; Gordon, L.; et al. The anthropocene: From global change to planetary stewardship. Ambio 2011, 40, 739-761. [CrossRef]

121. Zipper, S.C.; Jaramillo, F.; Wang-Erlandsson, L.; Cornell, S.E.; Gleeson, T.; Porkka, M.; Häyhä, T.; Crépin, A.; Fetzer, I.; Gerten, D.; et al. Integrating the Water Planetary Boundary With Water Management From Local to Global Scales. Earth's Future 2020, 8. [CrossRef]

122. Postel, S.L. Water for Food Production: Will There Be Enough in 2025? Bioscience 1998, 48, 629-637. [CrossRef]

123. DeFraiture, C.; Molden, D.; Amarasinghe, U.; Makin, I. PODIUM: Projecting water supply and demand for food production in 2025. Phys. Chem. Earth, Part B Hydrol. Ocean. Atmos. 2001, 26, 869-876. [CrossRef]

124. Steffen, W.; Richardson, K.; Rockström, J.; Cornell, S.; Fetzer, I.; Bennett, E.; Biggs, R.; Carpenter, S.; de Vries, W.; de Wit, C.; et al. Planetary boundaries: Guiding changing planet. Science 2015, 347, 1-12. [CrossRef] [PubMed]

125. Nordhaus, T.; Shellenberger, M.; Blomqvist, L. The Planetary Boundaries Hypothesis: Review of the Evidence; Breakthrough Institute: Oakland, CA, USA, 2012.

126. Rockström, J.; Steffen, W.; Noone, K.; Persson, Å.; Chapin, F.S.I.; Lambin, E.; Lenton, T.M.; Scheffer, M.; Folke, C.; Schellnhuber, H.J.; et al. Planetary Boundaries: Exploring the Safe Operating Space for Humanity. Ecol. Soc. 2009, 14, 32. [CrossRef]

127. Berger, M.; van der Ent, R.; Eisner, S.; Bach, V.; Finkbeiner, M. Water Accounting and Vulnerability Evaluation (WAVE): Considering Atmospheric Evaporation Recycling and the Risk of Freshwater Depletion in Water Footprinting. Environ. Sci. Technol. 2014, 48, 4521-4528. [CrossRef] [PubMed]

128. He, C.; Huang, G.; Liuc, L.; Li, Y.; Zhang, X.; Xu, X. Multi-dimensional diagnosis model for the sustainable development of regions facing water scarcity problem: A case study for Guangdong, China. Sci. Total Environ. 2020, 734, 139394. [CrossRef]

129. Quinteiro, P.; Ridoutt, B.G.; Arroja, L.; Dias, A.C. Identification of methodological challenges remaining in the assessment of a water scarcity footprint: A review. Int. J. Life Cycle Assess. 2018, 23, 164-180. [CrossRef]

130. Huang, J.; Ridoutt, B.G.; Thorp, K.R.; Wang, X.; Lan, K.; Liao, J.; Tao, X.; Wu, C.; Huang, J.; Chen, F.; et al. Water-scarcity footprints and water productivities indicate unsustainable wheat production in China. Agric. Water Manag. 2019, 224, 105744. [CrossRef] 
131. Rodell, M.; Famiglietti, J.; Wiese, D.N.; Reager, J.T.; Beaudoing, H.K.; Landerer, F.W.; Lo, M.-H. Emerging Trends in Global Freshwater Availability. Nature 2018, 557, 651-659. [CrossRef]

132. Richey, A.S.; Thomas, B.F.; Lo, M.-H.; Reager, J.T.; Famiglietti, J.S.; Voss, K.; Swenson, S.C.; Rodell, M. Quantifying renewable groundwater stress with GRACE. Water Resour. Res. 2015, 51, 5217-5237. [CrossRef] [PubMed]

133. Falkenmark, M. Water resilience and human life support-Global outlook for the next half century. Int. J. Water Resour. Dev. 2020, 36, 377-396. [CrossRef]

134. Wang-Erlandsson, L.; van der Ent, R.J.; Gordon, L.J.; Savenije, H.H.G. Contrasting roles of interception and transpiration in the hydrological cycle-Part 1: Temporal characteristics over land. Earth Syst. Dyn. 2014, 5, 441-469. [CrossRef]

135. van der Ent, R.J.; Wang-Erlandsson, L.; Keys, P.W.; Savenije, H.H.G. Contrasting roles of interception and transpiration in the hydrological cycle-Part 2: Moisture recycling. Earth Syst. Dyn. Discuss. 2014, 5, 281-326.

136. Bunsri, T.; Sivakumar, M.; Hagare, D. Simulation of water movement through unsaturated infiltration-redistribution system. J. Appl. Fluid Mech. 2009, 2, 45-53.

137. Eekhout, J.P.C.; Hunink, J.E.; Terink, W.; de Vente, J. Why increased extreme precipitation under climate change negatively affects water security. Hydrol. Earth Syst. Sci. 2018, 22, 5935-5946. [CrossRef]

138. Maeda, E.E.; Pellikka, P.K.E.; Clark, B.J.F.; Siljander, M. Prospective changes in irrigation water requirements caused by agricultural expansion and climate changes in the eastern arc mountains of Kenya. J. Environ. Manag. 2011, 92, 982-993. [CrossRef] [PubMed]

139. Smerdon, B.D. A synopsis of climate change effects on groundwater recharge. J. Hydrol. 2017, 555, 125-128. [CrossRef]

140. Taylor, R.G.; Scanlon, B.; Döll, P.; Rodell, M.; Beek, R.; Van Longuevergne, L.; Leblanc, M.; Famiglietti, J.S.; Edmunds, M. Groundwater and climate change: Recent advances and a look forward. Nat. Clim. Chang. 2013, 3, 322-329. [CrossRef]

141. Emori, S.; Brown, S.J. Dynamic and thermodynamic changes in mean and extreme precipitation under changed climate. Geophys. Res. Lett. 2005, 32, 1-5. [CrossRef]

142. Rao, K.K.; Patwardhan, S.K.; Kulkarni, A.; Kamala, K.; Sabade, S.S.; Kumar, K.K. Projected changes in mean and extreme precipitation indices over India using PRECIS. Glob. Planet. Chang. 2014, 113, 77-90. [CrossRef]

143. Shongwe, M.E.; van Oldenborgh, G.J.; van den Hurk, B.J.J.M.; de Boer, B.; Coelho, C.A.S.; van Aalst, M.K. Projected changes in mean and extreme precipitation in Africa under global warming. Part I: Southern Africa. J. Clim. 2009, 22, 3819-3837. [CrossRef]

144. Shongwe, M.E.; van Oldenborgh, G.J.; van den Hurk, B.; van Aalst, M. Projected changes in mean and extreme precipitation in Africa under global warming. Part II: East Africa. J. Clim. 2011, 24, 3718-3733. [CrossRef]

145. Meixner, T.; Manning, A.; Stonestrom, D.A.; Allen, D.M.; Ajami, H.; Blasch, K.W.; Brookfield, A.E.; Castro, C.L.; Clark, J.F.; Gochis, D.J.; et al. Implications of projected climate change for groundwater recharge in the western United States. J. Hydrol. 2016, 534, 124-138. [CrossRef]

146. Rosa, L.; Rulli, M.C.; Davis, K.F.; Chiarelli, D.D.; Passera, C.; D'Odorico, P. Closing the yield gap while ensuring water sustainability. Environ. Res. Lett. 2018, 13, 1-13. [CrossRef]

147. Schyns, J.F.; Hoekstra, A.Y.; Booij, M.J. Review and classification of indicators of green water availability and scarcity. Hydrol. Earth Syst. Sci. 2015, 19, 4581-4608. [CrossRef]

148. Schyns, J.F.; Hoekstra, A.Y.; Booij, M.J.; Hogeboom, R.J.; Mekonnen, M.M. Limits to the world's green water resources for food, feed, fiber, timber, and bioenergy. Proc. Natl. Acad. Sci. USA 2019, 116, 4893-4898. [CrossRef] [PubMed]

149. Schyns, J.F.; Hoekstra, A.Y.; Booij, M.J.; Hogeboom, R.J.; Mekonnen, M.M. Supplement: Limits to the world's green water resources for food, feed, fiber, timber, and bioenergy. Proc. Natl. Acad. Sci. USA 2019, 116, 4893-4898. [CrossRef]

150. Zhu, K.; Xie, Z.; Zhao, Y.; Lu, F.; Song, X.; Li, L.; Song, X. The assessment of Green Water Based on the SWAT Model: A case study in the Hai River Basin, China. Water 2018, 10, 798. [CrossRef]

151. Velpuri, N.M.; Senay, G.B. Partitioning Evapotranspiration into Green and Blue Water Sources in the Conterminous United States. Sci. Rep. 2017, 7, 1-12.

152. Pieper, M.; Kupfer, T.; Thylmann, D.; Bos, U. Introduction to Water Assessment in GaBi Version 2.2. 2018. Available online: https:/ / www.gabi-software.com/fileadmin/Documents/Introduction_to_Water_Assessment_V2.2_03.pdf (accessed on 21 February 2021).

153. Quinteiro, P.; Rafael, S.; Vicente, B.; Marta-Almeida, M.; Rocha, A.; Arroja, L.; Dias, A.C. Mapping green water scarcity under climate change: A case study of Portugal. Sci. Total Environ. 2019, 696, 134024. [CrossRef]

154. Liang, J.; Liu, G.; Zhang, H.; Li, X.; Qian, Z.; Lei, M.; Li, X.; Peng, Y.; Li, S.; Zeng, G. Interactive effects of climate variability and human activities on blue and green water scarcity in rapidly developing watershed. J. Clean. Prod. 2020, 265, 121834. [CrossRef]

155. Herrnegger, M.; Nachtnebel, H.P.; Haiden, T. Evapotranspiration in high alpine catchments-an important part of the water balance! Hydrol. Res. 2012, 43, 460-475. [CrossRef]

156. Dahl, M.; Nilsson, B.; Langhoff, J.H.; Refsgaard, J.C. Review of classification systems and new multi-scale typology of groundwater-surface water interaction. J. Hydrol. 2007, 344, 1-16. [CrossRef]

157. Kong, J.; Xin, P.; Hua, G.-F.; Luo, Z.-Y.; Shen, C.-J.; Chen, D.; Li, L. Effects of vadose zone on groundwater table fluctuations in unconfined aquifers. J. Hydrol. 2015, 528, 397-407. [CrossRef]

158. Ringersma, J.; Batjes, N.; Dent, D. Green Water: Definitions and Data for Assessment; ISRIC-World Soil Information: Wageningen, The Netherlands, 2003.

159. Andrade, R.; Rangarajan, R. Transient resistivity response to infiltrating water front through vadose zone. HydroResearch 2019, 2, 12-20. [CrossRef] 
160. Karlberg, L.; Rockström, J.; Falkenmark, M. Water resource implications of upgrading rainfed agriculture-Focus of green and blue water trade-offs. In Rainfed Agriculture: Unlocking the Potential; Wani, S.P., Rockström, J., Oweis, T., Eds.; CABI (CAB International): Wallingford, UK, 2009; pp. 44-53.

161. Gerrits, A.M.J.; Savenije, H.H.G. Interception. In Treatise on Water Science; Wilderer, P., Ed.; Academic Press: Oxford, UK, 2011; Volume 2, pp. 89-101.

162. Gerrits, A.M.J.; Savenije, H.H.G.; Veling, E.J.M.; Pfister, L. Analytical derivation of the Budyko curve based on rainfall characteristics and a simple evaporation model. Water Resour. Res. 2009, 45, 1-15. [CrossRef]

163. Lathuillière, M.J.; Coe, M.T.; Johnson, M.S. A review of green-and blue-water resources and their trade-offs for future agricultural production in the Amazon Basin: What could irrigated agriculture mean for Amazonia? Hydrol. Earth Syst. Sci. 2016, 20, 2179-2194. [CrossRef]

164. Hoekstra, A.Y. Green-blue water accounting in a soil water balance. Adv. Water Resour. 2018, 129, 112-117. [CrossRef]

165. Mao, G.; Liu, J.; Zheng, Y.T.Á.Y.Z.Á.C. Assessing the interlinkage of green and blue water in an arid catchment in Northwest China. Environ. Geochem. Health 2020, 42, 933-953. [CrossRef]

166. Chen, D.; Chen, H.W. Using the Köppen classification to quantify climate variation and change: An example for 1901-2010. Environ. Dev. 2013, 6, 69-79. [CrossRef]

167. Beck, H.E.; Zimmermann, N.E.; McVicar, T.R.; Vergopolan, N.; Berg, A.; Wood, E.F. Present and future köppen-geiger climate classification maps at 1-km resolution. Sci. Data 2018, 5, 1-12. [CrossRef]

168. Hegerl, G.C.; Broennimann, S.; Cowan, T.; Friedman, A.R.; Hawkins, E.; Iles, C.E.; Mueller, W.; Schurer, A.; Undorf, S. Causes of climate change over the historical record. Environ. Res. Lett. 2019, 14, 123006. [CrossRef]

169. Barker, S.; Knorr, G.; Edwards, R.L.; Parrenin, F.; Putnam, A.E.; Skinner, L.C.; Wolff, E.; Ziegler, M. 800,000 Years of abrupt climate variability. Science 2011, 334, 347-351. [CrossRef]

170. Kottek, M.; Grieser, J.; Beck, C.; Rudolf, B.; Rubel, F. World map of the Köppen-Geiger climate classification updated. Meteorol. Zeitschrift 2006, 15, 259-263. [CrossRef]

171. Aldieri, C.P.; Vinci, L. Climate Change and Knowledge Spillovers for Cleaner Production. J. Clean. Prod. 2020, $271,122729$. [CrossRef]

172. UNFCCC. Climate Change Science-The Status of Climate Change Science Today; United Nations Framework Convention on Climate Change (UNFCCC): Bonn, Germany, 2011.

173. Deser, C.; Phillips, A.S.; Alexander, M.A.; Smoliak, B.V. Projecting North American climate over the next 50 years: Uncertainty due to internal variability. J. Clim. 2014, 27, 2271-2296. [CrossRef]

174. Wallace, J.M.; Deser, C.; Smoliak, B.V.; Phillips, A.S. Attribution of Climate Change in the Presence of Internal Variability. In Climate Change: Multidecadal and Beyond; Chang, C.-P., Ghil, M., Latif, M., Wallace, J.M., Eds.; World Scientific: Singapore, 2015; pp. 1-29.

175. Hoerling, M.; Eischeid, J.; Perlwitz, J. Regional precipitation trends: Distinguishing natural variability from anthropogenic forcing. J. Clim. 2010, 23, 2131-2145. [CrossRef]

176. Martel, J.L.; Mailhot, A.; Brissette, F.; Caya, D. Role of natural climate variability in the detection of anthropogenic climate change signal for mean and extreme precipitation at local and regional scales. J. Clim. 2018, 31, 4241-4263. [CrossRef]

177. Khan, N.; Shahid, S.; Chung, E.S.; Behlil, F.; Darwish, M.S.J. Spatiotemporal changes in precipitation extremes in the arid province of Pakistan with removal of the influence of natural climate variability. Theor. Appl. Climatol. 2020, 142, 1447-1462. [CrossRef]

178. Winsberg, E. Values and uncertainties in the predictions of global climate models. Kennedy Inst. Ethics J. 2012, 22, $111-137$. [CrossRef]

179. Palmer, T.N.; Doblas-Reyes, F.J.; Hagedorn, R.; Weisheimer, A. Probabilistic prediction of climate using multi-model ensembles: From basics to applications. Philos. Trans. R. Soc. B Biol. Sci. 2005, 360, 1991-1998. [CrossRef] [PubMed]

180. Palmer, T.; Buizza, R.; Hagedorn, R.; Lawrence, A.; Leutbecher, M.; Smith, L.A. Ensemble prediction: A pedagogical perspective. ECMWF Newsl. 2006, 106, 10-17.

181. Hagedorn, R.; Doblas-Reyes, F.J.; Palmer, T.N. The rationale behind the success of multi-model ensembles in seasonal forecastingI. Basic concept. Tellus A Dyn. Meteorol. Oceanogr. 2005, 57, 219-233.

182. Pappenberger, F.; Bartholmes, J.; Thielen, J.; Anghel, E. TIGGE: Medium Range Multi Model Weather Forecast Ensembles in Flood Forecasting (a Case Study); ECMWF: Reading, UK, 2008; p. 557.

183. Li, S.; Robertson, A.W. Evaluation of submonthly precipitation forecast skill from global ensemble prediction systems. Mon. Weather Rev. 2015, 143, 2871-2889. [CrossRef]

184. Arnell, N.W.; Lowe, J.A.; Challinor, A.J.; Osborn, T.J. Global and regional impacts of climate change at different levels of global temperature increase. Clim. Chang. 2019, 155, 377-391. [CrossRef]

185. Pitman, A.J.; Arneth, A.; Ganzeveld, L. Review: Regionalizing global climate models. Int. J. Climatol. 2012, 32, 321-337. [CrossRef]

186. Pierce, D.W.; Barnett, T.P.; Santer, B.D.; Gleckler, P.J. Selecting global climate models for regional climate change studies. Proc. Natl. Acad. Sci. USA 2009, 106, 8441-8446. [CrossRef]

187. Feser, F.; Rrockel, B.; Storch, H.; Winterfeldt, J.; Zahn, M. Regional climate models add value to global model data a review and selected examples. Bull. Am. Meteorol. Soc. 2011, 92, 1181-1192. [CrossRef]

188. de Castro, M.; Gallardo, C.; Jylha, K.; Tuomenvirta, H. The use of a climate-type classification for assessing climate change effects in Europe from an ensemble of nine regional climate models. Clim. Chang. 2007, 81 (Suppl. 1), 329-341. [CrossRef] 
189. Christensen, J.H.; Kjellström, E.; Giorgi, F.; Lenderink, G.; Rummukainen, M. Weight assignment in regional climate models. Clim. Res. 2010, 44, 179-194. [CrossRef]

190. Kendon, E.J.; Ban, N.; Roberts, N.M.; Fowler, H.J.; Roberts, M.J.; Chan, S.C.; Evans, J.P.; Fosser, G.; Wilkinson, J.M. Do convectionpermitting regional climate models improve projections of future precipitation change? Bull. Am. Meteorol. Soc. 2017, 98, 79-94. [CrossRef]

191. Vörösmarty, C.J.; Green, P.; Salisbury, J.; Lammers, R.B. Global water resources: Vulnerability from climate change and population growth. Science 2000, 289, 284-288. [CrossRef]

192. Bates, B.C.; Kundzewicz, Z.W.; Wu, S.; Palutikof, J.P. (Eds.) Climate Change and Water; Intergovernmental Panel on Climate Change: Geneva, Switzerland, 2007.

193. Dore, M.H.I. Climate change and changes in global precipitation patterns: What do we know? Environ. Int. 2005, 31, 1167-1181. [CrossRef] [PubMed]

194. Seneviratne, S.I.; Donat, M.G.; Pitman, A.J.; Knutti, R.; Wilby, R.L. Allowable CO2 emissions based on regional and impact-related climate targets. Nature 2016, 529, 477-483. [CrossRef] [PubMed]

195. Arnell, N.W.; Brown, S.; Gosling, S.N.; Hinkel, J.; Huntingford, C.; Lloyd-Hughes, B.; Lowe, J.A.; Osborn, T.; Nicholls, R.J.; Żelazowski, P. Global-scale climate impact functions: The relationship between climate forcing and impact. Clim. Chang. 2016, 134, 475-487. [CrossRef]

196. Hocke, K. Relation between short-term and long-term variations of precipitation. Climate 2017, 5, 96. [CrossRef]

197. Fatichi, S.; Ivanov, V.Y.; Caporali, E. Investigating interannual variability of precipitation at the global scale: Is there a connection with seasonality? J. Clim. 2012, 25, 5512-5523. [CrossRef]

198. Allan, R.P.; Soden, B.J. Atmosphere Warming and the Amplification of Precipitation Extremes. Science 2008, 321, 1481-1484. [CrossRef]

199. Kummu, M.; Gerten, D.; Heinke, J.; Konzmann, M.; Varis, O. Climate-driven interannual variability of water scarcity in food production: A global analysis. Hydrol. Earth Syst. Sci. Discuss. 2013, 10, 6931-6962.

200. Smirnov, O.; Zhang, M.; Xiao, T.; Orbell, J.; Lobben, A.; Gordon, J. The relative importance of climate change and population growth for exposure to future extreme droughts. Clim. Chang. 2016, 138, 41-53. [CrossRef]

201. Gosling, S.N.; Arnell, N.W. A global assessment of the impact of climate change on water scarcity. Clim. Chang. 2016, 134, 371-385. [CrossRef]

202. Fox-Rabinovitz, M.; Côté, J.; Dugas, B.; Déqué, M.; McGregor, J.L. Variable resolution general circulation models: Stretched-grid model intercomparison project (SGMIP). J. Geophys. Res. Atmos. 2006, 111, 1-21. [CrossRef]

203. Buizza, R. Horizontal resolution impact on short- and long-range forecast error. Q. J. R. Meteorogical Soc. 2010, 136, 1020-1035. [CrossRef]

204. Kim, I.W.; Oh, J.; Woo, S.; Kripalani, R.H. Evaluation of precipitation extremes over the Asian domain: Observation and modelling studies. Clim. Dyn. 2019, 52, 1317-1342. [CrossRef]

205. Cole, J.J.; Prairie, Y.T.; Caraco, N.F.; McDowell, W.; Tranvik, L.J.; Striegl, R.G.; Duarte, C.M.; Kortelainen, P.; Downing, J.A.; Middelburg, J.; et al. Plumbing the global carbon cycle: Integrating inland waters into the terrestrial carbon budget. Ecosystems 2007, 10, 171-184. [CrossRef]

206. Tranvik, L.J.; Downing, J.A.; Cotner, J.B.; Loiselle, S.; Striegl, R.G.; Ballatore, T.J.; Dillon, P.; Finlay, K.; Fortino, K.; Knoll, L.B.; et al. Lakes and reservoirs as regulators of carbon cycling and climate. Limnol. Oceanogr. 2009, 54, 2298-2314. [CrossRef]

207. Eichenlaub, V.L. Lakes, effects on climate. In Climatology. Encyclopedia of Earth Science; Springer: Boston, MA, USA, 1987.

208. O'Reilly, C.M.; Sharma, S.; Gray, D.K.; Hampton, S.E.; Read, J.S.; Rowley, R.; Schneider, P.; Lenters, J.D.; McIntyre, P.B.; Kraemer, B.M.; et al. Rapid and highly variable warming of lake surface waters around the globe. Geophys. Res. Lett. 2015, 42, 10773-10781. [CrossRef]

209. Jeppesen, L.; Søndergaard, E.; Lauridsen, M.; Liboriussen, T.L.; Bjerring, R.; Johanssen, F.; Landkildehus, L.S.; Kronvang, B.; Andersen, H.E.; Trolle, D. Recent climate induced changes in freshwaters in Denmark. In Climatic Change and Global Warming of Inland Waters: Impacts and Mitigation for Ecosystems and Societies; Goldman, C.R., Kumagari, M., Robarts, R.D., Eds.; John Wiley \& Sons: Hoboken, NJ, USA, 2012; pp. 156-171.

210. Llopart, M.; Coppola, E.; Giorgi, F.; da Rocha, R.P.; Cuadra, S.V. Climate change impact on precipitation for the Amazon and La Plata basins. Clim. Chang. 2014, 125, 111-125. [CrossRef]

211. Xu, R.; Hu, H.; Tian, F.; Li, C.; Khan, M.Y.A. Projected climate change impacts on future streamflow of the Yarlung TsangpoBrahmaputra River. Glob. Planet. Chang. 2019, 175, 144-159. [CrossRef]

212. Trenberth, K.E. Changes in precipitation with climate change. Clim. Res. 2011, 47, 123-138. [CrossRef]

213. Chou, C.; Chiang, J.C.H.; Lan, C.W.; Chung, C.H.; Liao, Y.C.; Lee, C.J. Increase in the range between wet and dry season precipitation. Nat. Geosci. 2013, 6, 263-267. [CrossRef]

214. Konapala, G.; Mishra, A.; Leung, L.R. Changes in temporal variability of precipitation over land due to anthropogenic forcings. Environ. Res. Lett. 2017, 12, 024009. [CrossRef]

215. Schurer, A.P.; Ballinger, A.P.; Friedman, A.R.; Hegerl, G.C. Human influence strengthens the contrast between tropical wet and dry regions. Environ. Res. Lett. 2020, 15, 1-12. [CrossRef]

216. Hirji, R.; Ibrekk, H.O. Environmental and Water Resources Management; Environment Strategy Paper No. 2; World Bank, Environment Department: Washington, DC, USA, 2001. 
217. Destouni, G.; Asokan, S.M.; Jarsj, J. Inland hydro-climatic interaction: Effects of human water use on regional climate. Geophys. Res. Lett. 2010, 37, 1-6. [CrossRef]

218. Farsani, I.F.; Farzaneh, M.R.; Besalatpour, A.A.; Salehi, M.H.; Faramarzi, M. Assessment of the impact of climate change on spatiotemporal variability of blue and green water resources under CMIP3 and CMIP5 models in a highly mountainous watershed. Theor. Appl. Climatol. 2019, 136, 169-184. [CrossRef]

219. Shrestha, N.K.; Du, X.; Wang, J. Assessing climate change impacts on fresh water resources of the Athabasca River Basin, Canada. Sci. Total Environ. 2018, 601-602, 425-440. [CrossRef]

220. Chen, Z.; Grasby, S.E.; Osadetz, K.G. Relation between climate variability and groundwater levels in the upper carbonate aquifer, southern Manitoba, Canada. J. Hydrol. 2004, 290, 43-62. [CrossRef]

221. Green, T.R.; Taniguchi, M.; Kooi, H.; Gurdak, J.J.; Allen, D.M.; Hiscock, K.M.; Treidel, H.; Aureli, A. Beneath the surface of global change: Impacts of climate change on groundwater. J. Hydrol. 2011, 405, 532-560. [CrossRef]

222. Dettinger, M.; Udall, B.; Georgakakos, A. Western water and climate change. Ecol. Appl. 2015, 25, 2069-2093. [CrossRef] [PubMed]

223. Clifton, C.F.; Day, K.T.; Luce, C.H.; Grant, G.E.; Safeeq, M.; Halofsky, J.E.; Staab, B.P. Effects of climate change on hydrology and water resources in the Blue Mountains, Oregon, USA. Clim. Serv. 2018, 10, 9-19. [CrossRef]

224. Gober, P.; Kirkwood, C.W. Vulnerability assessment of climate-induced water shortage in Phoenix. Proc. Natl. Acad. Sci. USA 2010, 107, 21295-21299. [CrossRef] [PubMed]

225. Backlund, P.; Janetos, A.; Schimel, D. The Effects of Climate Change on Agriculture, Land Resources, Water Resources, and Biodiversity in the United States; U.S. Environmental Protection Agenc: Washington, DC, USA, 2008.

226. Seneviratne, S.I.; Wilhelm, M.; Stanelle, T.; Hurk, B.V.D.; Hagemann, S.; Berg, A.; Cheruy, F.; Higgins, M.E.; Meier, A.; Brovkin, V.; et al. Impact of soil moisture-climate feedbacks on CMIP5 projections: First results from the GLACE-CMIP5 experiment. Geophys. Res. Lett. 2013, 40, 5212-5217. [CrossRef]

227. Fischer, E.M.; Sedláček, J.; Hawkins, E.; Knutti, R. Models agree on forced response pattern of precipitation and temperature extremes. Geophys. Res. Lett. 2014, 41, 8554-8562. [CrossRef]

228. Molden, D.; Frenken, K.; Barker, R.; de Fraiture, C.; Mati, B.; Svendsen, M.; Sadoff, C.W.; Finlayson, M.; Atapattu, S.; Giordano, M.; et al. Trends in water and agricultural development. In Water for Food, Water for Life: A Comprehensive Assessment of Water Management in Agriculture; Molden, D., Ed.; Earthscan: London, UK; International Water Management Institute: Colombo, Sri Lanka, 2007; pp. 57-89.

229. Falkenmark, M.; Lannerstad, M. Consumptive water use to feed humanity-Curing a blind spot. Hydrol. Earth Syst. Sci. 2005, 9 , 15-28. [CrossRef]

230. Shiklomanov, I.A. Appraisal and Assessment of World Water Resources. Water Int. 2000, 25, 11-32. [CrossRef]

231. Peel, M.C.; Finlayson, B.L.; McMahon, T.A. Updated world map of the Köppen-Geiger climate classification. Hydrol. Earth Syst. Sci. 2007, 11, 1633-1644. [CrossRef]

232. Alcamo, J.; Henrichs, T. Critical regions: A model-based estimation of world water resources sensitive to global changes. Aquat. Sci. 2002, 64, 352-362. [CrossRef]

233. Srinivasan, V.; Lambin, E.F.; Gorelick, S.M.; Thompson, B.H.; Rozelle, S. The nature and causes of the global water crisis: Syndromes from a meta-analysis of coupled human-water studies. Water Resour. Res. 2012, 48, W10516. [CrossRef]

234. Thomas, B.F.; Famiglietti, J.S. Identifying Climate-Induced Groundwater Depletion in GRACE Observations. Sci. Rep. 2019, 9 , 1-9. [CrossRef]

235. Wu, W.-Y.; Lo, M.-H.; Wada, Y.; Famiglietti, J.S.; Reager, J.T.; Yeh, P.J.-F.; Ducharne, A.; Yang, Z.-L. Divergent effects of climate change on future groundwater availability in key mid-latitude aquifers. Nat. Commun. 2020, 11, 1-9. [CrossRef] [PubMed]

236. Gurdak, J.J. Climate-induced pumping. Nat. Geosci. 2017, 10, 71-72. [CrossRef]

237. Strosser, P.; Dworak, T.; Delvaux, P.A.G.; Berglund, M.; Schmidt, G.; Mysiak, J.; Kossida, M.; Iacovides, I.; Ashton, V. Gap Analysis of the Water Scarcity and Droughts Policy in the EU; Gap Analysis of the Water Scarcity and Droughts Policy in the EU, European Commission Tender: Brussels, Belgium, 2012.

238. Orth, R.; Destouni, G. Drought reduces blue-water fluxes more strongly than green-water fluxes in Europe. Nat. Commun. 2018, 9, 8. [CrossRef] [PubMed]

239. Semmler, T.; Jacob, D. Modeling extreme precipitation events-A climate change simulation for Europe. Glob. Planet Chang. 2004, 44, 119-127. [CrossRef]

240. Fleig, A.K.; Tallaksen, L.M.; James, P.; Hisdal, H.; Stahl, K. Attribution of European precipitation and temperature trends to changes in synoptic circulation. Hydrol. Earth Syst. Sci. 2015, 19, 3093-3107. [CrossRef]

241. Frei, C.; Schöll, R.; Fukutome, S.; Schmidli, J.; Vidale, P.L. Future change of precipitation extremes in Europe: Intercomparison of scenarios from regional climate models. J. Geophys. Res. Atmos. 2006, 111. [CrossRef]

242. Nikulin, A.; Kjellström, G.; Hansson, E.; Strandberg, U.; Ullerstig, G. Evaluation and future projections of temperature, precipitation and wind extremes over Europe in an ensemble of regional climate simulations. Tellus A 63:41-55. Tellus A 2011, 63, 41-55. [CrossRef]

243. Beniston, M.; Stephenson, D.B.; Christensen, O.B.; Ferro, C.A.T.; Frei, C.; Goyette, S.; Halsnæs, K.; Holt, T.; Jylhä, K.; Koffi, B.; et al. Future extreme events in European climate: An exploration of regional climate model projections. Clim. Chang. 2007, 81 (Suppl. 1), 71-95. [CrossRef] 
244. Min, S.K.; Zhang, X.; Zwiers, F.W.; Hegerl, G.C. Human contribution to more-intense precipitation extremes. Nature 2011, 470, 378-381. [CrossRef]

245. Kelemen, A.; Munch, W.; Poelman, H.; Gakova, Z.; Dijkstra, L.; Torighelli, B. Regions 2020, an Assessment of Future Challenges for E.U. Regions 2868; European Commission: Brussels, Belgium, 2009.

246. Dankers, R.; Hiederer, R. Extreme Temperatures and Precipitation in Europe: Analysis of a High-Resolution Climate Change Scenario; JRC Scientific and Technical Reports; European Commission Joint Research Centre Institute for Environment and Sustainability: Brussels, Belgium, 2008.

247. Lavers, D.A.; Villarini, G. The contribution of atmospheric rivers to precipitation in Europe and the United States. J. Hydrol. 2015, 522, 382-390. [CrossRef]

248. Alpert, P.; Ben-Gai, T.; Baharad, A.; Benjamini, Y.; Yekutieli, D.; Colacino, M.; Diodato, L.; Ramis, C.; Homar, V.; Romero, R.; et al. The paradoxical increase of Mediterranean extreme daily rainfall in spite of decrease in total values. Geophys. Res. Lett. 2002, 29, 1-4. [CrossRef]

249. Black, E.; Brayshaw, D.J.; Rambeau, C.M.C. Past, present and future precipitation in the Middle East: Insights from models and observations. Philos. Trans. R. Soc. A Math. Phys. Eng. Sci. 2010, 368, 5173-5184. [CrossRef]

250. Qian, B.; Xu, H. Spatial-Temporal Structure of Quasi-Periodic Oscillations in Precipitation over Europe. Int. J. Climatol. 2000, 20, 1583-1598. [CrossRef]

251. Leander, R.; Buishand, T.A.; Tank, A.M.G.K. An alternative index for the contribution of precipitation on very wet days to the total precipitation. J. Clim. 2014, 27, 1365-1378. [CrossRef]

252. Sánchez, M.; Gallardo, E.; Gaertner, C.; Arribas, M.; Castro, A. Future climate extreme events in the Mediterranean simulated by a regional climate model: A first approach. Glob. Planet Chang. 2004, 44, 163-180. [CrossRef]

253. Rajczak, J.; Pall, P.; Schär, C. Projections of extreme precipitation events in regional climate simulations for Europe and the Alpine Region. J. Geophys. Res. Atmos. 2013, 118, 3610-3626. [CrossRef]

254. Gao, X.; Pal, J.S.; Giorgi, F. Projected changes in mean and extreme precipitation over the Mediterranean region from a high resolution double nested RCM simulation. Geophys. Res. Lett. 2006, 33, 2-5. [CrossRef]

255. Mourato, S.; Moreira, M.; Corte-Real, J. Interannual variability of precipitation distribution patterns in Southern Portugal. Int. J. Climatol. 2010, 30, 1784-1794. [CrossRef]

256. van den Besselaar, E.J.M.; Tank, A.M.G.K.; Buishand, T.A. Trends in European precipitation extremes over 1951-2010. Int. J. Climatol. 2013, 33, 2682-2689. [CrossRef]

257. Hagemann, S.; Chen, C.; Clark, D.B.; Folwell, S.; Gosling, S.N.; Haddeland, I.; Hanasaki, N.; Heinke, J.; Ludwig, F.; Voss, F.; et al. Climate change impact on available water resources obtained using multiple global climate and hydrology models. Earth Syst. Dyn. 2013, 4, 129-144. [CrossRef]

258. Benateau, S.; Gaudard, A.; Stamm, C.; Altermatt, F. Climate Change and Freshwater Ecosystems: Impacts on Water Quality and Ecological Status; Hydro-CH2018 Project. Federal Office for the Environment (FOEN): Bern, Switzerland, 2019.

259. Mastrotheodoros, T.; Pappas, C.; Molnar, P.; Burlando, P.; Manoli, G.; Parajka, J.; Rigon, R.; Szeles, B.; Bottazzi, M.; Hadjidoukas, P.; et al. More green and less blue water in the Alps during warmer summers. Nat. Clim. Chang. 2020, 10, 155-161. [CrossRef]

260. Nilsen, I.B.; Fleig, A.K.; Tallaksen, L.M.; Hisdal, H. Recent trends in monthly temperature and precipitation patterns in Europe. IAHS-AISH Proc. Rep. 2014, 363, 132-137.

261. Giannini, A.; Biasutti, M.; Held, I.M.; Sobel, A.H. A global perspective on African climate. Clim. Chang. 2008, 90, 359-383. [CrossRef]

262. Niang, I.; Ruppel, O.C.; Abdrabo, M.A.; Essel, A.; Lennard, C.; Padgham, J.; Urquhart, P. Africa. In Climate Change 2014: Impacts, Adaptation and Vulnerability; Contribution of Working Group II to the Fifth Assessment Report of the Intergovernmental Panel on Climate Change; Cambridge University Press: Cambridge, UK, 2014; pp. 1199-1265.

263. U.N. Population 2030: Demographic Challenges and Opportunities for Sustainable Development Planning; U.N.: New York, NY, USA, 2015.

264. Marshall, M.; Funk, C.; Michaelsen, J. Examining evapotranspiration trends in Africa. Clim Dyn 2012, 38, 1849-1865. [CrossRef]

265. U.N. Probabilistic Projections Population Indicators Sub-Sahara. In Department of Economic and Social Affairs Population Dynamics; U.N.: New York, NY, USA, 2020. Available online: https://population.un.org/wpp/Download/Probabilistic/Population/ (accessed on 22 April 2021).

266. Beck, L.; Bernauer, T. How will combined changes in water demand and climate affect water availability in the Zambezi river basin? Glob. Environ. Chang. 2011, 21, 1061-1072. [CrossRef]

267. Chiang, J.C.H.; Sobel, A.H. Tropical Tropospheric Temperature Variations Caused by ENSO and Their Influence on the Remote Tropical Climate. J. Clim. 2002, 15, 2616-2631. [CrossRef]

268. Carter, R.; Parker, A. Climate Change, population Trends and Groundwater in Africa. Hydrol. Sci. J. 2009, 54, 676-689. [CrossRef]

269. Hulme, M. Rainfall changes in Africa: 1931-1960 to 1961-1990. Int. J. Clim. 2002, 12, 685-699. [CrossRef]

270. Rushton, K.R.; Eilers, V.H.M.; Carter, R.C. Improved soil moisture balance methodology for recharge estimation. J. Hydrol. 2006, 318, 379-399. [CrossRef]

271. Mafuta, C. The Value of Green Water Management in Sub-Saharan Africa: A Review. J. Contemp. Water Res. Educ. 2018, 165, 67-75. [CrossRef] 
272. Amogu, O.; Descroix, L.; Yéro, K.S.; Le Breton, É.; Mamadou, I.; Ali, A.; Vischel, T.; Bader, J.-C.; Moussa, I.B.; Gautier, E.; et al. Increasing river flows in the Sahel? Water 2010, 2, 170-199. [CrossRef]

273. Descroix, L.; Mahé, G.; Lebel, T.; Favreau, G.; Galle, S.; Gautier, E.; Olivry, J.-C.; Albergel, J.; Amogu, O.; Cappelaere, B.; et al. Spatio-temporal variability of hydrological regimes around the boundaries between Sahelian and Sudanian areas of West Africa: A synthesis. J. Hydrol. 2009, 375, 90-102. [CrossRef]

274. Kundzewicz, Z.; Doll, P. Will groundwater ease freshwater stress under climate change? Hydrol. Sci. J. 2009, 54, 665-675. [CrossRef]

275. Wang, L.; Dochartaigh, B.Ó.; Macdonald, D. A Literature Review of Recharge Estimation and Groundwater Resource Assessment in Africa; British Geological Survey: London, UK, 2010.

276. Gbobaniyi, E.; Sarr, A.; Sylla, M.B.; Diallo, I.; Lennard, C.; Dosio, A.; Dhiédiou, A.; Kamga, A.; Klutse, N.A.B.; Hewitson, B.; et al. Climatology, annual cycle and interannual variability of precipitation and temperature in CORDEX simulations over West Africa. Int. J. Climatol. 2014, 34, 2241-2257. [CrossRef]

277. Stanzel, P.; Kling, H.; Bauer, H. Climate change impact on West African rivers under an ensemble of CORDEX climate projections. Clim. Serv. 2018, 11, 36-48. [CrossRef]

278. Diffenbaugh, N.S.; Giorgi, F. Climate change hotspots in the CMIP5 global climate model ensemble model ensemble. Clim. Chang. 2012, 114, 813-822. [CrossRef] [PubMed]

279. Giannini, A.; Saravanan, R.; Chang, P. Oceanic Forcing of Sahel Rainfall on Interannual to Interdecadal. Science 2003, 302, 1027-1030. [CrossRef] [PubMed]

280. WASH Cluster Somalia and UNICEF, Water, Sanitation, and Hygiene Assessment Report Somalia—December 2019; UNICEF: New York, NY, USA, 2019.

281. Alam, U.Z. Questioning the Water Wars Rationale: A Case Study of the Indus Waters Treaty. Geogr. J. 2002, 168, $341-353$. [CrossRef]

282. UNFCC. Climate Change: Impacts, Vulnerabilities and Adaptation in Developing Countries; UNFCCC: New York, USA, 2012.

283. Dosio, A.; Jones, R.G.; Jack, C.; Lennard, C.; Nikulin, G.; Hewitson, B. What can we know about future precipitation in Africa? Robustness, significance and added value of projections from a large ensemble of regional climate models. Clim. Dyn. 2019, 53, 5833-5858. [CrossRef]

284. Kundzewicz, Z.W.; Mata, L.J.; Arnell, N.W.; Döll, P.; Kabat, P.; Jimenez, B.; Miller, K.A.; Oki, T.; Sen, Z.; Shiklomanov, I.A. Freshwater Resources and Their Management in Climate Change 2007: Impacts, Adaptation and Vulnerability; Contribution ofWorking Group II to the Fourth Assessment Report of the Intergovernmental Panel on Climate, Change; Parry, M.L., Canziani, O.F., Palutikof, J.P., van der Linden, P.J., Hanson, C.E., Eds.; Cambridge University Press: Cambridge, UK, 2007; pp. 173-210.

285. Arndt, D.S.; Baringer, M.O.; Johnson, M.R. State of the climate in 2009. Bull. Am. Meteorol. Soc. 2010, 91. [CrossRef]

286. Zhang, Y.; Tang, C.; Ye, A.; Zheng, T.; Nie, X.; Tu, A.; Zhu, H.; Zhang, S. Impacts of climate and land-use change on blue and green water: A case study of the Upper Ganjiang river basin, China. Water 2020, 12, 1-18. [CrossRef]

287. Yuan, Z.; Xu, J.; Meng, X.; Wang, Y.; Yan, B.; Hong, X. Impact of climate variability on blue and green water flows in the Erhai Lake Basin of Southwest China. Water 2019, 11, 424. [CrossRef]

288. Du, J.; Jia, Y.; Hao, C.; Qiu, Y.; Niu, C.; Liu, H. Temporal and spatial changes of blue water and green water in the Taihang Mountain Region, China, in the past 60 years. Hydrol. Sci. J. 2019, 63, 2040-2056. [CrossRef]

289. Zang, C.F.; Liu, J.; van der Velde, M.; Kraxner, F. Assessment of spatial and temporal patterns of green and blue water flows under natural conditions in inland river basins in Northwest China. Hydrol. Earth Syst. Sci. 2012, 16, 2859-2870. [CrossRef]

290. Gosain, A.K.; Rao, S.; Arora, A. Climate change impact assessment of water resources of India. Curr. Sci. 2011, 101, 356-371.

291. Lee, M.-H.; Bae, D.-H. Climate Change Impact Assessment on Green and Blue Water over Asian Monsoon Region. Water Resour. Manag. 2015, 29, 2407-2427. [CrossRef]

292. Immerzeel, W.W.; van Beek, L.P.H.; Bierkens, M.F.P. Climate change will affect the asian water towers. Science 2010, 328, 1382-1385. [CrossRef]

293. Naveendrakumar, G.; Vithanage, M.; Kwon, H.-H.; Chandrasekara, S.; Iqbal, M.; Pathmarajah, S.; Fernando, K.; Obeysekera, J. South Asian perspective on temperature and rainfall extremes: A review. Atmos. Res. 2019, 225, 110-120. [CrossRef]

294. Almazroui, M.; Saeed, S.; Saeed, F.; Islam, M.N.; Ismail, M. Projections of Precipitation and Temperature over the South Asian Countries in CMIP6. Earth Syst. Environ. 2020, 4, 297-320. [CrossRef]

295. Endo, N.; Matsumoto, J.; Lwin, T. Trends in precipitation extremes over Southeast Asia. Sci. Online Lett. Atmos. 2009, 5, 168-171. [CrossRef]

296. Yao, C.; Qian, W.; Yang, S.; Lin, Z. Regional features of precipitation over Asia and summer extreme precipitation over Southeast Asia and their associations with atmospheric-oceanic conditions. Meteorol. Atmos. Phys. 2010, 106, 57-73. [CrossRef]

297. Lioubimtseva, E.; Henebry, G.M. Climate and environmental change in arid Central Asia: Impacts, vulnerability, and adaptations. J. Arid Environ. 2009, 73, 963-977. [CrossRef]

298. IMF. Too Slow for Too Long; IMF: Washington, DC, USA, 2016.

299. El-Beltagy, A.; Madkour, M. Impact of climate change on arid lands agriculture. Agric. Food Secur. 2012, 1, 1-12. [CrossRef]

300. el Kharraz, J.; El-Sadek, A.; Ghaffour, N.; Mino, E. Water scarcity and drought in WANA countries. Procedia Eng. 2012, 33, 14-29. [CrossRef] 
301. Rosegrant, M.W.; Cai, X. Global Water Demand and Supply Projections: Part 2. Results and Prospects to 2025. Water Int. 2002, 27, 170-182. [CrossRef]

302. Mohammed, T.; Al-Amin, A.Q. Climate change and water resources in Algeria: Vulnerability, impact and adaptation strategy. Econ. Environ. Stud. 2018, 18, 411-429. [CrossRef]

303. Rahmani, A.; Brahim, C. Water Supply Prediction for the Next 10 Years in Algeria: Risks and Challenges. Irrig. Drain. Syst. Eng. 2017, 6, 1-7.

304. Schilling, J.; Hertig, E.; Tramblay, Y.; Scheffran, J. Climate change vulnerability, water resources and social implications in North Africa. Reg. Environ. Chang. 2020, 20, 15. [CrossRef]

305. Zeroual, A.; Assani, A.A.; Meddi, H.; Bouabdelli, S.; Zeroual, S.; Alkama, R. Assessment of Projected Precipitations and Temperatures Change Signals over Algeria Based on Regional Climate Model: RCA4 Simulations. In Water Resources in AlgeriaPart I Assessment of Surface and Groundwater Resources; Negm, A.M., Bouderbala, A., Chenchouni, H., Barceló, D., Eds.; Springer: Berlin, Germany, 2020; pp. 135-159.

306. Oduor, A.R.; Gadain, H.M. Potential of Rainwater Harvesting in Somalia; EU-FAO, Somalia Water and Land Information Management: Mogadishu, Somalia, 2007.

307. African Development Bank Group. Improving Access to Water and Sanitation Services in Somalia; African Development Bank Group: Abidjan, Côte d'Ivoire, 2016.

308. Noman, A.A.; Al-Jailani, J. Investigation of the potential of fogwater harvesting in the Western Mountainous parts of the Yemen. Arab Gulf J. Sci. Res. 1989, 25, 50-58.

309. Giesecke, C. Yemen's Water Crisis Review of Background and Potential Solutions; USAID Knowledge Services Center: Washington, DC, USA, 2012.

310. Hadil, M.; Elayah, M.; Schuplen, L. Yemen between the Impact of the Climate Change and the Ongoing Saudi-Yemen War: A Real Tragedy; GPBC and CIDIN: Nijmegen, The Netherlands, 2017.

311. Egyptian Ministry of Resources and Irrigation. Water for the Future: National Water Resources Plan For Egypt-2017; Ministry of Water Resources and Irrigation (Egypt): Cairo, Egypt, 2005.

312. McKenzie, S. Egypt's Choice: From the Nile Basin Treaty to the Cooperative Framework Agreement, an International Legal Analysis. Transnatl. Law Contemp. Probl. 2012, 21, 571-598.

313. Wheeler, K.G.; Jeuland, M.; Hall, J.W.; Zagona, E.; Whittington, D. Understanding and managing new risks on the Nile with the Grand Ethiopian Renaissance Dam. Nat. Commun. 2020, 11, 1-9. [CrossRef]

314. Abdel-Dayem, S. Water quality management in Egypt. Int. J. Water Resour. Dev. 2011, 27, 181-202. [CrossRef]

315. UNDP. Egypt's National Strategy for Adaptation to Climate Change and Disaster Risk Reduction; The Egyptian Cabinet Information and Decision Support Center: Cairo, Egypt, 2011.

316. Conway, D. The climate and hydrology of the Upper Blue Nile river. Geogr. J. 2000, 166, 49-62. [CrossRef]

317. Elshamy, M.E.; Seierstad, I.A.; Sorteberg, A. Impacts of climate change on Blue Nile flows using bias-corrected GCM scenarios. Hydrol. Earth Syst. Sci. 2009, 13, 551-565. [CrossRef]

318. Sušnik, J.; Vamvakeridou-Lyroudia, L.S.; Baumert, N.; Kloos, J.; Renaud, F.G.; La Jeunesse, I.; Mabrouk, B.; Savić, D.A.; Kapelan, Z.; Ludwig, R.; et al. Interdisciplinary assessment of sea-level rise and climate change impacts on the lower Nile delta, Egypt. Sci. Total Environ. 2015, 503-504, 279-288. [CrossRef]

319. Coffel, E.D.; Keith, B.; Lesk, C.; Horton, R.M.; Bower, E.; Lee, J.; Mankin, J.S. Future Hot and Dry Years Worsen Nile Basin Water Scarcity Despite Projected Precipitation Increases. Earth's Futur. 2019, 7, 967-977. [CrossRef]

320. Agrawala, S.; Moehner, A.; Raey, M.E.; Conway, D.; van Aalst, M.; Hagenstad, M.; Smith, J. Development and Climate Change in Egypt: Focus on Coastal Resources and the Nile; OECD: Paris, France, 2004.

321. Gosling, S.N.; Dunn, R.; Carrol, F.; Christidis, N.; Fullwood, J.; de Gusmao, D.; Golding, N.; Good, L.; Hall, T.; Kendon, L.; et al. Climate: Observations, Projections and Impacts; Met Office Hadley Centre: Exeter, UK, 2011.

322. Ludwig, F.; Vellinga, P. Impacts of Climate Change on Water Resource Management in Egypt and The Netherlands. In $42 n d$ Meeting of the Egyptian-Dutch Advisory Panel on Water Management; MWRI: Cairo, Egypt; Alterra: Wageningen, The Netherlands, 2008.

323. Assaf, H.; Erian, W.; Gafrej, R.; Herrmann, S.; McDonnell, R.; Taimeh, A. Adaptation to a Changing Climate in the Arab Countries. In Adaptation to a Changing Climate in the Arab Countries; Verner, D., Ed.; World Bank: Washington, DC, USA, $2012 ;$ pp. $109-151$.

324. Kelley, C.P.; Mohtadi, S.; Cane, M.A.; Seager, R.; Kushnir, Y. Climate change in the Fertile Crescent and implications of the recent Syrian drought. Proc. Natl. Acad. Sci. USA 2015, 112, 3241-3246. [CrossRef] [PubMed]

325. Abbas, N.; Wasimi, S.A.; Al-Ansari, N. Climate Change Impacts on Water Resources of Greater Zab River, Iraq. J. Civ. Eng. Archit. 2016, 10, 1384-1402.

326. Procházka, P.; Hönig, V.; Maitah, M.; Pljucarská, I.; Kleindienst, J. Evaluation of Water Scarcity in Selected Countries of the Middle East. Water 2018, 10, 1482. [CrossRef]

327. Herein, M.; Drótos, G.; Haszpra, T.; Márfy, J.; Tél, T. The theory of parallel climate realizations as a new framework for teleconnection analysis. Sci. Rep. 2017, 7, 1-11. [CrossRef] [PubMed]

328. Ouachani, R.; Bargaoui, Z.; Ouarda, T. Power of teleconnection patterns on precipitation and streamflow variability of upper Medjerda Basin. Int. J. Climatol. 2013, 33, 58-76. [CrossRef]

329. Westra, S.; Renard, B.; Thyer, M. The ENSO-precipitation teleconnection and its modulation by the interdecadal pacific oscillation. J. Clim. 2015, 28, 4753-4773. [CrossRef] 
330. Baek, S.H.; Smerdon, J.E.; Coats, S.; Williams, A.P.; Cook, B.I.; Cook, E.R.; Seager, R. Precipitation, temperature, and teleconnection signals across the combined North American, monsoon Asia, and old world drought atlases. J. Clim. 2017, 30, 7141-7155. [CrossRef] [PubMed]

331. Mamalakis, A.; Yu, J.Y.; Randerson, J.T.; Aghakouchak, A.; Foufoula-Georgiou, E. A new interhemispheric teleconnection increases predictability of winter precipitation in southwestern US. Nat. Commun. 2018, 9, 1-10. [CrossRef] [PubMed]

332. Plewa, K.; Perz, A.; Wrzesiński, D. Links between teleconnection patterns and water level regime of selected Polish lakes. Water 2019, 11, 1-19. [CrossRef]

333. Bódai, T.; Drótos, G.; Ha, K.-J.; Lee, J.-Y.; Haszpra, T.; Chung, E.-S. Nonlinear forced change and nonergodicity: The case of ENSO-Indian monsoon and global precipitation teleconnections. In Proceedings of the JpGU-AGU Joint Meeting 2020 For a borderless World of Geoscience, Chiba, Japan, 24-28 May 2020; pp. 1-31.

334. Keys, P.W.; Barnes, E.A.; van der Ent, R.J.; Gordon, L.J. Variability of moisture recycling using a precipitationshed framework. Hydrol. Earth Syst. Sci. 2014, 18, 3937-3950. [CrossRef]

335. Adler, R.F.; Gu, G.; Sapiano, M.; Wang, J.J.; Huffman, G.J. Global Precipitation: Means, Variations and Trends During the Satellite Era (1979-2014). Surv. Geophys. 2017, 38, 679-699. [CrossRef]

336. Davey, M.K.; Brookshaw, A.; Ineson, S. The probability of the impact of ENSO on precipitation and near-surface temperature. Clim. Risk Manag. 2014, 1, 5-24. [CrossRef]

337. Abtew, W.; Melesse, A.M.; Dessalegne, T. El Nino Southern Oscillation link to the Blue Nile River Basin hydrology. Hydrol. Process. 2009, 23, 3653-3660. [CrossRef]

338. Abtew, W.; Melesse, A. Climate Teleconnections and Water Management. In Nile River Basin; Melesse, A., Abtew, W., Setegn, S., Eds.; Springer: Berlin, Germany, 2014; pp. 7-21.

339. Alhamshry, A.; Fenta, A.A.; Yasuda, H.; Shimizu, K.; Kawai, T. Prediction of summer rainfall over the source region of the Blue Nile by using teleconnections based on sea surface temperatures. Theor. Appl. Climatol. 2019, 137, 3077-3087. [CrossRef]

340. Eltahir, E.A.B. El Nino and the natural variability of the Nile River. Water Resour. Res. 1991, 32, 131-1376. [CrossRef]

341. Molla, F.; Kebede, A.; Raju, U.J.P. The Impact of the El-Niño Southern Oscillation Precipitation and the Surface Temperature over the Upper Blue Nile Region. J. Sci. Res. Rep. 2019, 21, 1-15. [CrossRef]

342. Arpe, K.; Bengtsson, L.; Golitsyn, G.S.; Mokhov, I.I.; Semenov, V.A.; Sporyshev, P.V. Connection between Caspian Sea level variability and ENSO. Geophys. Res. Lett. 2000, 27, 2693-2696. [CrossRef]

343. Roghani, R.; Soltani, S.; Bashari, H. Influence of southern oscillation on autumn rainfall in Iran (1951-2011). Theor. Appl. Climatol. 2015, 124, 411-423. [CrossRef]

344. Dehghani, M.; Salehi, S.; Mosavi, A.; Nabipour, N.; Shamshirband, S.; Ghamisi, P. Spatial analysis of seasonal precipitation over Iran: Co-variation with climate indices. ISPRS Int. J. Geo-Information 2020, 9, 73. [CrossRef]

345. Huang, R.; Wu, Y. The influence of ENSO on the summer climate change in China and its mechanism. Adv. Atmos. Sci. 1989, 6, 21-32.

346. Hasanean, H. Precipitation variability over the Mediterranean and its linkage with El Nino Southern Oscillation (ENSO). J. Meteorol. 2004, 29, 151-160.

347. Pozo-Vazquez, D.; Gámiz-Fortis, S.R.; Tovar-Pescador, J.; Esteban-Parra, M.J.; Castro-Díez, Y. El Niño-Southern Oscillation events and associated European winter precipitation anomalies. Int. J. Climatol. 2005, 25, 17-31. [CrossRef]

348. George, D.G. The impact of the North Atlantic Oscillation on the development of ice on Lake Windermere. Clim. Chang. 2007, 81, 455-468. [CrossRef]

349. Funk, C.; Dettinger, M.D.; Michaelsen, J.C.; Verdin, J.P.; Brown, M.; Barlow, M.; Hoell, A. Warming of the Indian Ocean threatens eastern and southern African food security but could be mitigated by agricultural development. Proc. Natl. Acad. Sci. USA 2008, 105, 11081-11086. [CrossRef]

350. Holman, I.P.; Rivas-Casado, M.; Bloomfield, J.P.; Gurdak, J.J. Identifying non-stationary groundwater level response to North Atlantic ocean-atmosphere teleconnection patterns using wavelet coherence. Hydrogeol. J. 2011, 19, 1269-1278. [CrossRef]

351. Kuss, A.J.M.; Gurdak, J.J. Groundwater level response in U.S. principal aquifers to ENSO, NAO, PDO, and AMO. J. Hydrol. 2014, 519, 1939-1952. [CrossRef]

352. Velasco, E.M.; Gurdak, J.J.; Dickinson, J.E.; Ferré, T.P.A.; Corona, C.R. Interannual to multidecadal climate forcings on groundwater resources of the U.S. West Coast. J. Hydrol. Reg. Stud. 2017, 11, 250-265. [CrossRef]

353. Rust, W.; Holman, I.; Bloomfield, J.; Cuthbert, M.; Corstanje, R. Understanding the potential of climate teleconnections to project future groundwater drought. Hydrol. Earth Syst. Sci. 2019, 23, 3233-3245. [CrossRef]

354. Abiy, A.Z.; Melesse, A.M.; Seyoum, W.M.; Abtew, W. Drought and climate teleconnection and drought monitoring. In Extreme Hydrology and Climate Variability; Melesse, A.M., Abtew, W., Senay, G., Eds.; Elsevier Inc.: Amsterdam, The Netherlands, 2019; pp. 275-295.

355. Amini, M.; Ghadami, M.; Fathian, F.; Modarres, R. Teleconnections between oceanic-atmospheric indices and drought over Iran using quantile regressions. Hydrol. Sci. J. 2020, 65, 2286-2295. [CrossRef]

356. Trenberth, K.E.; Branstator, G.W.; Arkin, P.A. Origins of the 1988 North American Drought. Science. Science 1988, $242,1640-1645$. [CrossRef] [PubMed]

357. Seager, R. The turn of the century North American drought: Global context, dynamics, and past analogs. J. Clim. 2007, 20, 5527-5552. [CrossRef] 
358. Mo, K.C.; Schemm, J.K.E.; Yoo, S.H. Influence of ENSO and the Atlantic Multidecadal Oscillation on drought over the United States. J. Clim. 2009, 22, 5962-5982. [CrossRef]

359. Räsänen, T.A.; Lindgren, V.; Guillaume, J.H.A.; Buckley, B.M.; Kummu, M. On the spatial and temporal variability of ENSO precipitation and drought teleconnection in mainland Southeast Asia. Clim. Past 2016, 12, 1889-1905. [CrossRef]

360. Meza, F.J. Recent trends and ENSO influence on droughts in Northern Chile: An application of the Standardized Precipitation Evapotranspiration Index. Weather Clim. Extrem. 2013, 1, 51-58. [CrossRef]

361. Park, S.; Kang, D.; Yoo, C.; Im, J.; Lee, M.-I. Recent ENSO influence on East African drought during rainy seasons through the synergistic use of satellite and reanalysis data. ISPRS J. Photogramm. Remote Sens. 2020, 162, 17-26. [CrossRef]

362. Lau, W.K.M.; Kim, K.M. The 2010 Pakistan flood and Russian heat wave: Teleconnection of hydrometeorological extremes. J. Hydrometeorol. 2012, 13, 392-403. [CrossRef]

363. Hooshyaripor, F.; Faraji-Ashkavar, S.; Koohyian, F.; Tang, Q.; Noori, R. Annual flood damage influenced by El Niño in the Kan River basin, Iran. Nat. Hazards Earth Syst. Sci. 2020, 20, 2739-2751. [CrossRef]

364. Wang, S.Y.S.; Huang, W.R.; Hsu, H.H.; Gillies, R.R. Role of the strengthened El Niño teleconnection in the May 2015 floods over the southern Great Plains. Geophys. Res. Lett. 2015, 42, 8140-8146. [CrossRef]

365. Najibi, N.; Devineni, N.; Lu, M. Hydroclimate drivers and atmospheric teleconnections of long duration floods: An application to large reservoirs in the Missouri River Basin. Adv. Water Resour. 2017, 100, 153-167. [CrossRef]

366. Wu, Y.; Gough, W.A. The teleconnection between floods in the middle reaches of the Yangtze River and El Niño events. In Proceedings of the Predictions in Ungauged Basins: PUB Kick-Off (Proceedings of the PUB Kick-Off Meeting, Brasilia, Brazil, 20-22 November 2002; Volume 14, pp. 376-380.

367. Kundzewicz, Z.W.; Szwed, M.; Pińskwar, I. Climate variability and floods-A global review. Water 2019, 11, 1399. [CrossRef]

368. Whan, K.; Zwiers, F. The impact of ENSO and the NAO on extreme winter precipitation in North America in observations and regional climate models. Clim. Dyn. 2017, 48, 1401-1411. [CrossRef]

369. Lü, J.; Li, Y.; Zhai, P.; Chen, J.; Zhao, T. Teleconnection Patterns Impacting on the Summer Consecutive Extreme Rainfall in Central-Eastern China. In Proceedings of the 40th NOAA Annual Climate Diagnostics and Prediction Workshop, Denver, CO, USA, 26-29 October 2015; pp. 1-5.

370. Deng, Y.; Jiang, W.; He, B.; Chen, Z.; Jia, K. Change in Intensity and Frequency of Extreme Precipitation and its Possible Teleconnection With Large-Scale Climate Index Over the China From 1960 to 2015. J. Geophys. Res. Atmos. 2018, 123, $2068-2081$. [CrossRef]

371. Sun, X.; Renard, B.; Thyer, M.; Westra, S.; Lang, M. A global analysis of the asymmetric effect of ENSO on extreme precipitation. J. Hydrol. 2015, 530, 51-65. [CrossRef]

372. Shimizu, M.H.; Ambrizzi, T.; Liebmann, B. Extreme precipitation events and their relationship with ENSO and MJO phases over northern South America. Int. J. Climatol. 2017, 37, 2977-2989. [CrossRef]

373. Krichak, S.O.; Breitgand, J.S.; Gualdi, S.; Feldstein, S.B. Teleconnection-extreme precipitation relationships over the Mediterranean region. Theor. Appl. Climatol. 2014, 117, 679-692. [CrossRef]

374. Casanueva, A.; Rodríguez-Puebla, C.; Frías, M.D.; González-Reviriego, N. Variability of extreme precipitation over Europe and its relationships with teleconnection patterns. Hydrol. Earth Syst. Sci. 2014, 18, 709-725. [CrossRef]

375. Duzenli, E.; Tabari, H.; Willems, P.; Yilmaz, M.T. Decadal variability analysis of extreme precipitation in Turkey and its relationship with teleconnection patterns. Hydrol. Process. 2018, 32, 3513-3528. [CrossRef]

376. Brubaker, K.; Entekhabi, D.; Eagleson, P. Estimation of continental precipitation recycling. J. Clim. 1993, 6, 1077-1089. [CrossRef]

377. Brubaker, K.L.; Entekhabi, D. Analysis of Feedback Mechanisms in Land-Atmosphere Interaction Analysis of feedback mechanisms in land-atmosphere interaction. Water Resour. Res. 1996, 32, 1343-1357. [CrossRef]

378. Budyko, M.I.; Drozdov, O.A. Zakonomernosti vlagooborota v atmosfere (Regularities of the hydrologic cycle in the atmosphere). Izv. Akad. Nauk SSSR, Ser. Geogr. 1953, 4, 5-14.

379. Eltahir, E.A.B.; Bras, R.L. Precipitation recycling. Rev. Geophys. 1996, 34, 367-378. [CrossRef]

380. Burde, G.I.; Zangvil, A. The estimation of regional precipitation recycling. Part I: Review of recycling models. J. Clim. 2001, 14, 2497-2508. [CrossRef]

381. Dirmeyer, P.A.; Brubaker, K.L. Global characterization of the hydrologic cycle from a quasi-isentropic back-trajectory analysis of atmospheric water vapor. J. Hydrometeorol. 2007, 8, 20-37. [CrossRef]

382. Dirmeyer, P.A.; Brubaker, K.L.; DelSole, T. Import and export of atmospheric water vapor between nations. J. Hydrol. 2009, 365, 11-22. [CrossRef]

383. Dirmeyer, P.A.; Brubaker, K.L. Contrasting evaporative moisture sources during the drought of 1988 and the flood of 1993. J. Geophys. Res. 1999, 104, 19383-19397. [CrossRef]

384. Dirmeyer, P. What water vapor back-trajectory analysis can tell us about climate variability. In Proceedings of the 8th EGU Leonardo Conference 25 October 2016, Ourense, Spain, 25-27 October 2016.

385. Xie, P.; Arkin, P.A. Global precipitation: A 17-year monthly analysis based on gauge observations, satellite estimates, and numerical model outputs. Bull. Amer. Meteor. Soc. 1997, 78, 2539-2558. [CrossRef]

386. Stohl, A. Computation, accuracy and applications of trajectories-A review and bibliography. Atmos. Environ. 1998, 32, 947-966. [CrossRef] 
387. Kanamitsu, M.; Ebisuzaki, W.; Woollen, J.; Yang, S.-K.; Hnilo, J.J.; Fiorino, M.; Potter, G.L. NCEP-DOE AMIP-II reanalysis (R-2). Bull. Amer. Meteor. Soc. 2002, 83, 1631-1648. [CrossRef]

388. Bisselink, B.; Dolman, A.J. Precipitation recycling: Moisture sources over Europe using ERA-40 data. J. Hydrometeorol. 2008, 9 , 1073-1083. [CrossRef]

389. Dyn, C.; Hoyos, I.; Cañón, F.D.J.; Martínez, B.J.A. Moisture origin and transport processes in Colombia, northern South America. Clim. Dyn. Dyn. 2018, 50, 971-990.

390. Ryoo, J.; Waliser, D.E. Trajectory analysis on the origin of air mass and moisture associated with Atmospheric Rivers over the west coast of the United States. Atmos. Chem. Phys. Discuss. 2011, 11, 11109-11142.

391. Jana, S.; Rajagopalan, B.; Alexander, M.A.; Ray, A.J. Understanding the Dominant Sources and Tracks of Moisture for Summer Rainfall in the Southwest United States. J. Geophys. Res. Atmos. 2018, 123, 4850-4870. [CrossRef]

392. Hua, L.; Zhong, L.; Ke, Z. Characteristics of the precipitation recycling ratio and its relationship with regional precipitation in China. Theor. Appl. Climatol. 2017, 127, 513-531. [CrossRef]

393. Bosilovich, M.G.; Chern, J.D. Simulation of water sources and precipitation recycling for the MacKenzie, Mississippi, and Amazon River basins. J. Hydrometeorol. 2006, 7, 312-329. [CrossRef]

394. Nieto, R.; Gallego, D.; Trigo, R.; Ribera, P.; Gimeno, L. Dynamic identification of moisture sources in the Orinoco basin in equatorial South America. Hydrol. Sci. J. 2008, 53, 602-617. [CrossRef]

395. Shiklomanov, I.A. Anthropogenic effects on the hydrological cycle. In Hydrological Cycle-Volume I; Shiklomanov, I.A., Ed.; Unesco Eolss: New York, NY, USA, 1996; p. 7.

396. Keys, P.W.; van der Ent, R.J.; Gordon, L.J.; Hoff, H.; Nikoli, R.; Savenije, H.H.G. Analyzing precipitationsheds to understand the vulnerability of rainfall dependent regions. Biogeosciences 2012, 9, 733-746. [CrossRef]

397. Gimeno, L.; Stohl, A.; Trigo, R.M.; Dominguez, F.; Yoshimura, K.; Yu, L.; Drumond, A.; Durán-Quesada, A.M.; Nieto, R. Oceanic and terrestrial sources of continental precipitation. Rev. Geophys. 2012, 50, 1-41. [CrossRef]

398. de Vrese, P.; Hagemann, S.; Claussen, M. Asian irrigation, African rain: Remote impacts of irrigation. Geophys. Res. Lett. 2016, 43, 3737-3745. [CrossRef]

399. Stickler, C.M.; Coe, M.T.; Costa, M.; Nepstad, D.C.; McGrath, D.G.; Dias, L.C.P.; Rodrigues, H.O.; Soares-Filho, B.S. Dependence of hydropower energy generation on forests in the Amazon Basin at local and regional scales. Proc. Natl. Acad. Sci. USA 2013, 110, 9601-9606. [CrossRef] [PubMed]

400. Li, E.; Endter-Wada, J.; Li, S. Characterizing and Contextualizing the Water Challenges of Megacities. J. Am. Resour. Assovcation 2015, 51, 1-26. [CrossRef]

401. Keys, P.W.; Wang-Erlandsson, L.; Gordon, L.J. Megacity precipitationsheds reveal tele- connected water security challenges. PLoS ONE 2018. [CrossRef] [PubMed]

402. Chhabra, A.; Geist, H.; Houghton, R.A.; Haberl, H.; Braimoh, A.K.; Vlek, P.L.G.; Patz, J.; Xu, J.; Ramankutty, N.; Coomes, O. et al. Land-Use and Land-Cover Change: Loval Processes and Global Impacts. In Land-Use and Land-Cover Change: Loval Processes and Global Impacts; Lambin, E., Geist, H., Eds.; Springer: Berlin, Germany, 2006; pp. 71-116.

403. Mustard, J.F.; Desfries, R.S.; Fisher, T.; Moran, E. Land Use and Land Cover Change Pathways and Impacts. In Land Change Science: Observing, Monitoring, and Understanding Trajectories of Change on Earth's Surface; Gutman, G., Janetos, A.C., Justice, C.O., Moran, E.F., Mustard, J.F., Rindfuss, R.R., Skole, D., Turner, B.L.I., Cochrane, M.A., Eds.; Springer: Berlin, Germany, $2004 ;$ pp. $411-429$.

404. Hogeboom, R.J.; Knook, L.; Hoekstra, A.Y. The blue water footprint of the world's artificial reservoirs for hydroelectricity, irrigation, residential and industrial water supply, flood protection, fishing and recreation. Adv. Water Resour. 2018, 113, 285-294. [CrossRef]

405. Veldkamp, T.; Wada, Y.; Aerts, J.; Döll, P.; Gosling, S.N.; Liu, J.; Masaki, Y.; Oki, T.; Ostberg, S.; Pokhrel, Y.; et al. Water scarcity hotspots travel downstream due to human interventions in the 20th and 21st century. Nat. Commun. 2017, 8, 1-12. [CrossRef]

406. Fekete, B.M.; Wisser, D.; Mayorga, E.; Bouwman, L.; Vörösmarty, C.; Kroeze, C.; Wollheim, W. Millennium Ecosystem Assessment scenario drivers (1970-2050): Climate and hydrological alterations. Glob. Biogeochem. Cycles 2010, 24. [CrossRef]

407. Meyer, W.B.; Turner, B.L. Human population growth and global land cover change. Annu. Revis. Ecol. Syst. 1992, 23. [CrossRef]

408. Ruddiman, W.F. The anthropogenic greenhouse era began thousands of years ago. Clim. Chang. 2003, 61, 261-293. [CrossRef]

409. Krausmann, F.; Erb, K.; Gingrich, S.; Haberl, H.; Bondeau, A.; Gaube, V.; Lauk, C.; Plutzar, C.; Searchinger, T.D. Global human appropriation of net primary production doubled in the 20th century. Proc. Natl. Acad. Sci. USA 2013, 110, 10324-10329. [CrossRef] [PubMed]

410. Vitousek, P.M.; Ehrlich, P.R.; Ehrlich, A.H.; Matson, P.A. Human Appropriation of the Products of Photosynthesis. Am. Inst. Biol. Sci. Stable 1986, 36, 368-373. [CrossRef]

411. Rojstaczer, S.; Sterling, S.M.; Moore, N.J. Human Appropriation of Photosynthesis Products. Science 2001, $294,2549-2552$. [CrossRef]

412. Potter, C.; Klooster, S.; Genovese, V. Net primary production of terrestrial ecosystems from 2000 to 2009. Clim. Chang. 2012, 115, 365-378. [CrossRef]

413. Kazama, S.; Oki, T. The Effects of Climate Change on Water Resources. Clim. Res. 2011, 47, 77-82.

414. Ky, R. Impact of Climate Change on Water Resources. J. Earth Sci. Clim. Chang. 2014, 5, 1-6.

415. Trenberth, K.E. Climate change caused by human activities is happening and it already has major consequences. J. Energy Nat. Resour. Law 2018, 36, 463-481. [CrossRef] 
416. Wang, R.; Zimmerman, J. Hybrid Analysis of Blue Water Consumption and Water Scarcity Implications at the Global, National, and Basin Levels in an Increasingly Globalized World. Environ. Sci. Technol. 2016, 50, 5143-5153. [CrossRef]

417. Lade, S.J.; Steffen, W.; De Vries, W.; Carpenter, S.R.; Donges, J.F.; Gerten, D.; Hoff, H.; Newbold, T.; Richardson, K.; Rockström, J. Human impacts on planetary boundaries amplified by Earth system interactions. Nat. Sustain. 2019, 3, 119-128. [CrossRef]

418. Goldewijk, K.K. Estimating global land use change over the past 300 years: The HYDE database. Global Biogeochem. Cycles 2001, 15, 417-433. [CrossRef]

419. Delzeit, R.; Zabel, F.; Meyer, C.; Václavík, T. Addressing future trade-offs between biodiversity and cropland expansion to improve food security. Reg. Environ. Chang. 2017, 17, 1429-1441. [CrossRef]

420. FAO. Crop Production and Natural Resource Use FAO. 2020. Available online: http://www.fao.org/3/y4252e/y4252e06.htm (accessed on 22 April 2021).

421. Gregory, P.J.; George, T.S. Feeding nine billion: The challenge to sustainable crop production. J. Exp. Bot. 2011, 62, 5233-5239. [CrossRef]

422. Smith, P.; Gregory, P.J.; Van Vuuren, D.; Obersteiner, M.; Havlik, P.; Rounsevell, M.; Woods, J.; Stehfest, E.; Bellarby, J. Competition for land. Philos. Trans. R. Soc. B Biol. Sci. 2010, 365, 2941-2957. [CrossRef]

423. Eitelberg, D.A.; van Vliet, J.; Verburg, P.H. A review of global potentially available cropland estimates and their consequences for model-based assessments. Glob. Chang. Biol. 2015, 21, 1236-1248. [CrossRef] [PubMed]

424. Schmitz, C.; Van Meijl, H.; Kyle, P.; Nelson, G.C.; Fujimori, S.; Gurgel, A.C.; Havlik, P.; Heyhoe, E.; Mason-D’Croz, D.; Popp, A.; et al. Land-use change trajectories up to 2050: Insights from a global agro-economic model comparison. Agric. Econ. 2014, 45, 69-84. [CrossRef]

425. Defries, S.; Foley, A.; Asner, P. Balancing human needs and ecosystem function. Front. Ecol. Environ. 2004, 2, 249-257. [CrossRef]

426. Rodríguez, J.P.; Beard, J.T.D.; Bennett, E.M.; Cumming, G.; Cork, S.J.; Agard, J.; Dobson, A.P.; Peterson, G. Trade-offs across Space, Time, and Ecosystem Services. Ecol. Soc. 2006, 11, 1-14. [CrossRef]

427. Huq, N.; Bruns, A.; Ribbe, L. Interactions between freshwater ecosystem services and land cover changes in southern Bangladesh: A perspective from short-term (seasonal) and long-term (1973-2014) scale. Sci. Total Environ. 2020, 650, 132-143. [CrossRef]

428. Gordon, L.J.; Steffen, W.; Jönsson, B.F.; Folke, C.; Falkenmark, M.; Johannessen, Å. Human modification of global water vapor flows from the land surface. Proc. Natl. Acad. Sci. USA 2005, 102, 7612-7617. [CrossRef] [PubMed]

429. Verburg, P.H.; van Eck, J.R.R.; de Nijs, T.C.M.; Dijst, M.J.; Schot, P. Determinants of land-use change patterns in the Netherlands. Environ. Plan. B Plan. Des. 2004, 31, 125-150. [CrossRef]

430. Kissinger, G.; Herold, M.; de Sy, V. Drivers of Deforestation and Forest Degradation: A Synthesis for REDD+Policymakers Vancouver, Canada; Lexeme Consulting: Vancouver, BC, Canada, 2012.

431. Persson, M.; Henders, S.; Kastner, T. Trading Forests: Quantifying the Contribution of Global Commodity Markets to Emissions from Tropical Deforestation; Center for Global Development: Washington, DC, USA, 2014.

432. Heistermann, M.; Müller, C.; Ronneberger, K. Land in sight? Achievements, deficits and potentials of continental to global scale land-use modeling. Agric. Ecosyst. Environ. 2006, 114, 141-158. [CrossRef]

433. Land Matrix, Land Matrix: Africa. Available online: https://landmatrix.org/map (accessed on 21 February 2021).

434. Johansson, E.L.; Fader, M.; Seaquist, J.W.; Nicholas, K.A. Green and blue water demand from large-scale land acquisitions in Africa. Proc. Natl. Acad. Sci. USA 2016, 113, 11471-11476. [CrossRef] [PubMed]

435. Gibbs, H.K.; Ruesch, A.S.; Achard, F.; Clayton, M.K.; Holmgren, P.; Ramankutty, N.; Foley, J.A. Tropical forests were the primary sources of new agricultural land in the 1980s and 1990s. Proc. Natl. Acad. Sci. USA. 2010, 107, 16732-16737. [CrossRef] [PubMed]

436. Hosonuma, N.; Herold, M.; De Sy, V.; De Fries, R.S.; Brockhaus, M.; Verchot, L.; Angelsen, A.; Romijn, E. An assessment of deforestation and forest degradation drivers in developing countries. Environ. Res. Lett. 2012, 7, 044009. [CrossRef]

437. Zhang, X.; Zwiers, F.W.; Hegerl, G.; Lambert, F.H.; Gillett, N.P.; Solomon, S.; Stott, P.A.; Nozawa, T. Detection of human influence on twentieth-century precipitation trends. Nat. Lett. 2007, 448, 461-466. [CrossRef]

438. Stott, P.A. Attribution of regional-scale temperature changes to anthropogenic and natural causes. Geophys. Res. Lett. 2003, 30, 1-4. [CrossRef]

439. Garg, V.; Nikam, B.R.; Thakur, P.K.; Aggarwal, S.P.; Gupta, P.K.; Srivastav, S.K. Human-induced land use land cover change and its impact on hydrology. HydroResearch 2019, 1, 48-56. [CrossRef]

440. Balling, R.J. The climatic impacts of a Sonoran vegetation discontinuity. Clim. Chang. 1988, 13, 99-109. [CrossRef]

441. Campra, P.; Garcia, M.; Canton, Y.; Palacios-Orueta, A. Surface temperature cooling trends and negative radiative forcing due to land use change toward greenhouse farming in southeastern Spain. J. Geophys. Res. Atmos. 2008, 113, 1-10. [CrossRef]

442. Kvalevag, M.; Myhre, G.; Bonan, G.; Levis, S. Anthropogenic land cover changes in a GCM with surface albedo changes based on MODIS data. Int. J. Climatol. 2010, 30, 2105-2117. [CrossRef]

443. Davin, E.L.; de Noblet-Ducoudré, N.; Friedlingstein, P. Impact of land cover change on surface climate: Relevance of the radiative forcing concept. Geophys. Res. Lett. 2007, 34, 1-5. [CrossRef]

444. Lee, E.; Sacks, W.J.; Chase, T.N.; Foley, J.A. Simulated impacts of irrigation on the atmospheric circulation over Asia. J. Geophys. Res. Atmos. 2011, 116,1-13. [CrossRef]

445. Mahmood, R.; Sr, R.A.P.; Hubbard, K.G.; Niyogi, D.; Dirmeyer, P.A.; McAlpine, C.; Carleton, A.M.; Hale, R.; Gameda, S.; Beltrán-Przekurat, A.; et al. Land cover changes and their biogeophysical effects on climate. Int. J. Climatol. 2014, 34, 929-953. [CrossRef] 
446. Tolba, M.K.; El-Kholy, O.A. (Eds.) The World Environment 1972-1992: Two Decades of Challenge; Chapman \& Hall: London, UK, 1992.

447. Weaver, C.P.; Avissar, R. Atmospheric disturbances caused by human modification of the landscape. Bull. Am. Meteorol. Soc. 2001, 82, 269-282. [CrossRef]

448. Pielke, R.A.; Marland, G.; Betts, R.A.; Chase, T.N.; Eastman, J.L.; Niles, J.O.; Niyogi, D.D.S.; Running, S.W. The influence of land-use change and landscape dynamics on the climate system: Relevance to climate-change policy beyond the radiative effect of greenhouse gases. Philos. Trans. R. Soc. A Math. Phys. Eng. Sci. 2002, 360, 1705-1719. [CrossRef]

449. Avissar, R.; Werth, D. Global hydroclimatological teleconnections resulting from tropical deforestation. J. Hydrometeorol. 2005, 6, 134-145. [CrossRef]

450. Wang-Erlandsson, L.; Fetzer, I.; Keys, P.W.; van der Ent, R.J.; Savenije, H.H.G.; Gordon, L.J. Remote land use impacts on river flows through atmospheric teleconnections. Hydrol. Earth Syst. Sci. 2018, 22, 4311-4328. [CrossRef]

451. Wang, M.; Shao, Y.; Jiang, Q.; Xiao, L.; Yan, H.; Gao, X.; Wang, L.; Liu, P. Impacts of climate change and human activity on the runoff changes in the Guishui River Basin. Land 2020, 9, 291. [CrossRef]

452. Seneviratne, S.I.; Lüthi, D.; Litschi, M.; Schär, C. Land-atmosphere coupling and climate change in Europe. Nature 2006, 443, 205-209. [CrossRef] [PubMed]

453. Chan, D.; Wu, Q. Significant anthropogenic-induced changes of climate classes since 1950. Sci. Reports Nat. Publ. Gr. 2015, 4, 1-8. [CrossRef] [PubMed]

454. Magrin, G.O.; Marengo, J.A.; Boulanger, J.-P.; Buckeridge, M.S.; Castellanos, E.; Poveda, G.; Scarano, F.R.; Vicuña, S.; Alfaro, E.; Anthelme, F.; et al. Central and South America in Climate Change 2014: Impacts, Adaptation, and Vulnerability. Part B: Regional Aspects. Contribution of Working Group II to the Fifth Assessment Report of the Intergovernmental Panel on Climate Change; Barros, V.R., Field, C.B., Dokken, D.J., Mastrandrea, M.D., Mach, K.J., Bilir, T.E., Chatterjee, M., Ebi, K.L., Estrada, Y.O., Genova, R.C., et al., Eds.; Cambridge University Press: Cambridge, UK, 2014; pp. 1499-1566.

455. Pervez, S.; Henebry, G.M. Assessing the impacts of climate and land use and land cover change on the freshwater availability in the Brahmaputra River basin. J. Hydrol. Reg. Stud. 2015, 3, 285-311. [CrossRef]

456. Tekleab, S.; Mohamed, Y.; Uhlenbrook, S.; Wenninger, J. Hydrologic responses to land cover change: The case of Jedeb mesoscale catchment, Abay/Upper Blue Nile Basin, Ethiopia. Hydrol. Process. 2014, 28, 5149-5161. [CrossRef]

457. Berihun, M.L.; Tsunekawa, A.; Haregeweyn, N.; Meshesha, D.T.; Adgo, E.; Tsubo, M.; Masunaga, T.; Fenta, A.A.; Sultan, D.; Yibeltal, M.; et al. Hydrological responses to land use/land cover change and climate variability in contrasting agro-ecological environments of the Upper Blue Nile basin, Ethiopia. Sci. Total Environ. 2019, 689, 347-365. [CrossRef] [PubMed]

458. ESA Climate Change Initiative-Land Cover led by UC Louvain, Global Land Cover Maps 1992-2015. 2017. Available online: http:/ / maps.elie.ucl.ac.be/CCI/viewer/download.php (accessed on 22 April 2021).

459. Brink, A.B.; Eva, H.D. Monitoring 25 years of land cover change dynamics in Africa: A sample based remote sensing approach. Appl. Geogr. 2009, 29, 501-512. [CrossRef]

460. Ramankutty, N.; Foley, J.A.; Norman, J.; McSweeney, K. The global distribution of cultivable lands: Current patterns and sensitivity to possible climate change. Glob. Ecol. Biogeogr. 2002, 11, 377-392. [CrossRef]

461. Pitman, A.J.; De Noblet-Ducoudré, N.; Avila, F.B.; Alexander, L.V.; Boisier, J.P.; Brovkin, V.; Delire, C.; Cruz, F.; Donat, M.G.; Gayler, V.; et al. Effects of land cover change on temperature and rainfall extremes in multi-model ensemble simulations. Earth Syst. Dyn. Discuss. 2012, 3, 597-641.

462. Niu, X.; Tang, J.; Wang, S.; Fu, C. Impact of future land use and land cover change on temperature projections over East Asia. Clim. Dyn. 2019, 52, 6475-6490. [CrossRef]

463. Wu, M.; Schurgers, G.; Ahlström, A.; Rummukainen, M.; A Miller, P.; Smith, B.; May, W. Impacts of land use on climate and ecosystem productivity over the Amazon and the South American continent. Environ. Res. Lett. 2017, 12, 054016. [CrossRef]

464. Li, D.; Wang, L. Sensitivity of Surface Temperature to Land Use and Land Cover Change-Induced Biophysical Changes: The Scale Issue. Geophys. Res. Lett. 2019, 46, 9678-9689. [CrossRef]

465. Falkenmark, M.; Widstrand, C. Population and water resources: A delicate balance. Popul Bull 1992, 47, 1-36. [PubMed]

466. Ehrlich, P.R.; Ehrlich, A.H. Too Many People, Too Much Consumption Yale 360. 2008. Available online: https://e360.yale.edu/ features/too_many_people_too_much_consumption (accessed on 21 April 2021).

467. van Ypersele, J.P.; Bartiaux, F. The Role of Population Growth in Global Warming. In "International Population Conference", Inter-national Union for the Scientific Study of Population (IUSSP); Springer: Berlin, Germany, 1973; Volume 4, pp. 33-54.

468. Rosnick, D. The Consequences of Increased Population Growth for Climate Change; Center for Economic and Policy Research (CEPR): Washington, DC, USA, 2014.

469. Daly, H.E. Beyond Growth: The Economics of Sustainable Development; Beacon Press: Boston, MA, USA, 1996.

470. Henderson, K.; Loreau, M. An ecological theory of changing human population dynamics. People Nat. 2019, 1, 31-43. [CrossRef]

471. World Bank. Renewable Internal Freshwater Resources per Capita (Cubic Meters). 2014. Available online: https://data. worldbank.org/indicator /ER.H2O.INTR.PC?end=2014\&start=1970 (accessed on 22 April 2021).

472. Word Bank. Population, Total. 2019. Available online: https://data.worldbank.org/indicator/SP.POP.TOTL (accessed on 22 April 2021).

473. World Bank. Population, Total-Middle East \& North Africa. 2020. Available online: https://data.worldbank.org/indicator/SP. POP.TOTL? end=2014\&locations=ZQ\&start=1970 (accessed on 22 April 2021). 
474. Roudi-Fahimi, F.; Kent, M.M. Challenges and opportunities-The population of the Middle East and North Africa. Popul. Bull. 2007, 62, 1-19.

475. World Bank. Renewable Energy Desalination An Emerging Solution to Close the Water Gap in the Middle East and North Africa MENA Development Report; World Bank: Washington, DC, USA, 2012.

476. World Bank. Beyond Scarcity: Water Security in the Middle East and North Africa MENA Development Series; World Bank: Washington, DC, USA, 2017.

477. Bongaarts, J. Human population growth and the demographic transition. Philos. Trans. R. Soc. B Biol. Sci. 2009, 364, 2985-2990. [CrossRef]

478. Roser, M. Future Population Growth. In Our World in Data. Available online: https:/ / ourworldindata.org/future-populationgrowth (accessed on 22 February 2021).

479. Piguet, E.; Pécoud, A.; de Guchteneire, P. Migration and climate change: An overview. Refug. Surv. Q. 2011, 30, 1-23. [CrossRef]

480. Black, R.; Kniveton, D.; Skeldon, R.; Coppard, D.; Murata, A.; Schmidt-verkerk, K. Demographics and Climate Change: Future Trends And their Policy Implications for Migration T-27; Development Research Centre on Migration, Globalisation and Poverty, University of Sussex: Brighton, UK, 2008.

481. UNHCR. Supplementary Appeal: Somalia Situation 2017; UNHCR: Geneva, Switzerland, 2017.

482. Maastricht Graduate School of Governance (MGSoG). Somalia Migration Profile: Study on Migration Routes in the East and Horn of Africa; Maastricht Graduate School of Governance (MGSoG): Maastricht, The Netherlands, 2017.

483. AQUASTAT. Water Uses 2019. Available online: http:/ /www.fao.org/nr/water/aquastat/water_use/print1.stm (accessed on 22 April 2021).

484. Falkenmark, M.; Rockström, J.; Karlberg, L. Present and future water requirements for feeding humanity. Food Secur. 2009, 1, 59-69. [CrossRef]

485. Wada, Y.; Flörke, M.; Hanasaki, N.; Eisner, S.; Fischer, G.; Tramberend, S.; Satoh, Y.; van Vliet, M.T.H.; Yillia, P.; Ringler, C.; et al. Modeling global water use for the 21st century: The Water Futures and Solutions (WFaS) initiative and its approaches. Geosci. Model Dev. 2016, 9, 175-222. [CrossRef]

486. UN Water. The United Nations World Water Development Report 2018: Nature-Based Solutions for Water UNESCO; UN Water: Geneva, Switzerland, 2018.

487. Boretti, A.; Rosa, L. Reassessing the projections of the World Water Development Report. NPJ Clean Water 2019, 2, 15. [CrossRef]

488. U.N. Water. The United Nations World Water Development Report 2019: Leaving No One Behind; UN Water: Geneva, Switzerland, 2019.

489. Pitchford, J.D. Relative scarcity and uneven growth. Int. J. Soc. Econ. 1997, 24, 847-858. [CrossRef]

490. International Task Force on Global Public Goods. Meeting Global Challenges: International Cooperation in the National Interest Stockholm; International Task Force on Global Public Goods: Stockholm, Sweden, 2006.

491. Leagans, J.P. Concept of Needs. J. Ext. 1964, 2, 89-96.

492. Beatty, P.T. The concept of need: Proposal for a working definition. J. Community Dev. Soc. 1981, 12, 39-46. [CrossRef]

493. Samuelson, P.A. Economics: An Introductory Analysis; McGraw-Hill Book Company, Inc.: New York, NY, USA, 1955.

494. Thaler, R. Toward a positive theory of consumer choice. J. Econ. Behav. Organ. 1980, 1, 39-60. [CrossRef]

495. Kahneman, D.; Thaler, R.H. Anomalies: Utility maximization and experienced utility. J. Econ. Perspect. 2006, 20, 221-234. [CrossRef]

496. Hussien, W.A.; Memon, F.A. Assessing and Modelling the Influence of Household Characteristics on Per Capita Water Consumption Content courtesy of Springer Nature, terms of use apply Rights reserved. Water Resour. Manag. 2016. [CrossRef]

497. de Buck, E.; Borra, V.; de Weerdt, E.; Veegaete, A.V. A Systematic Review of the Amount of Water per Person per Day Needed to Prevent Morbidity and Mortality in (Post-) Disaster Settings. PLoS ONE 2015, 11, e0126395. [CrossRef]

498. Gleick, P.H.; Iwra, M. Basic Water Requirements. Water Int. 1996, 21, 83-92. [CrossRef]

499. WHO/SEARO. Minimum Water Quantity Needed for Domestic Uses; WHO/SEARO: Geneva, Switzerland, 2005.

500. Dalezios, N.R.; Angelakis, A.N.; Eslamian, S.S. Water scarcity management: Part 1: Methodological framework. Int. J. Glob. Environ. Issues 2018, 17, 1-40. [CrossRef]

501. Molden, D. Scarcity of water or scarcity of management? Int. J. Water Resour. Dev. 2020, 36, 258-268. [CrossRef]

502. FAO. Land and Water. 2020. Available online: http://www.fao.org/land-water/water/water-scarcity/en/ (accessed on 21 April 2021).

503. Bettini, Y.; Brown, R.; de Haan, F.J.; Science, E. Water scarcity and institutional change: Lessons in adaptive governance from the drought experience of Perth, Western. Water Sci. Technol. 2004, 67, 2160-2168. [CrossRef]

504. Barnes, J. Managing the waters of ba'th country: The politics of water scarcity in Syria. Geopolitics 2009, 14, 510-530. [CrossRef]

505. Wang, C.; Huang, H.; Zhou, J.; Deng, H.; Fang, C. Analysis of sustainable utilization of water resources based on the improved water resources ecological footprint model: A case study of Hubei Province, China. J. Environ. Manag. 2019, 262. [CrossRef]

506. Maruyama, T.; Kawachi, T.; Singh, V.P. Entropy-based assessment and clustering of potential water resources availability. J. Hydrol. 2005, 309, 104-113. [CrossRef]

507. Hoekstra, A.Y.; Mekonnen, M.M.; Chapagain, A.K.; Mathews, R.E.; Richter, B.D. Global monthly water scarcity: Blue water footprints versus blue water availability. PLoS ONE 2012, 7, 9. [CrossRef] [PubMed]

508. Faramarzi, M.; Abbaspour, K.C.; Schulin, R.; Yang, H. Modelling blue and green water resources availability in Iran. Hydrol. Process. 2009, 23, 486-501. [CrossRef] 
509. Schuol, J.; Abbaspour, K.C.; Yang, H.; Srinivasan, R.; Zehnder, A.J.B. Modeling blue and green water availability in Africa. Water Resour. Res. 2008, 44,1-18.

510. Xu, Z.; Zuo, D. Simulation of blue and green water resources in the Wei River basin, China in Evolving Water Resources Systems: Understanding, Predicting and Managing Water-Society Interactions. In Proceedings of the ICWRS2014, Bologna, Italy, 4-6 June 2014; pp. 486-491.

511. Sayyad, G.; Vasel, L.; Besalatpour, A.A.; Gharabaghi, B.; Golmohammadi, G. Modeling Blue and Green Water Resources Availability in an Iranian Data Scarce Watershed Using SWAT. J. Water Manag. Model. 2015, 1-8. [CrossRef]

512. Xu, H.; Wu, M. A first estimation of county-based greenwater availability and its implications for agriculture and bioenergy production in the United States. Water 2018, 10, 148. [CrossRef]

513. Badou, D.F.; Diekkrüger, B.; Kapangaziwiri, E.; Mbaye, M.L.; Yira, Y.; Lawin, E.A.; Oyerinde, G.T.; Afouda, A. Modelling blue and green water availability under climate change in the Beninese Basin of the Niger River Basin, West Africa. Hydrol. Process. 2018, 32, 2526-2542. [CrossRef]

514. Alamou, E.A.; Obada, E.; Afouda, A. Assessment of future water resources availability under climate change scenarios in the Mékrou Basin, Benin. Hydrology 2017, 4, 51. [CrossRef]

515. Sordo-Ward, A.; Granados, I.; Iglesias, A.; Garrote, L. Blue water in Europe: Estimates of current and future availability and analysis of uncertainty. Water 2019, 11, 420. [CrossRef]

516. Khan, S.; Guan, Y.; Khan, F.; Khan, Y. A Comprehensive Index for Measuring Water Security in an Urbanizing World: The Case of Pakistan's Capital. Water 2020, 12, 166. [CrossRef]

517. Reilly, T.E.; Dennehy, K.F.; Alley, W.M.; Cunningham, W.L. U.S.G.S. Circular 1323: Ground-Water Availability in the United States; U.S. Geological Survey: Reston, VA, USA, 2008.

518. MacDonald, A.M.; Bonsor, H.C.; Dochartaigh, B.É.Ó.; Taylor, R.G. Quantitative maps of groundwater resources in Africa. Environ. Res. Lett. 2012, 7, 024009. [CrossRef]

519. Al-Ghazawy, O. Africa floats on underground water reserves. Nat. Middle East. Available online: https://www.natureasia.com/ en/nmiddleeast/article/10.1038/nmiddleeast.2012.72 (accessed on 22 April 2021). [CrossRef]

520. National Agricultural Statistics Service. Irrigation and Water Management: Results from the 2018 Irrigation and Water Management Survey (Highlights); United States Department of Agriculture: Washington, DC, USA, 2019.

521. Fung, F.; Lopez, A.; New, M. Water availability in $+2^{\circ} \mathrm{C}$ and $+4^{\circ} \mathrm{C}$ worlds. Philos. Trans. R. Soc. A Math. Phys. Eng. Sci. 2011, 369, 99-116. [CrossRef]

522. Latrubesse, E.M. Patterns of anabranching channels: The ultimate end-member adjustment of Mega Rivers. Geomorphology 2008, 101, 130-145. [CrossRef]

523. Czaya, E. Rivers of the World; Cambridge University Press: Cambridge, UK, 1985.

524. Allan, J.A. Virtual water: A strategic resource. Global solutions to regional deficits Ground Water. Ground Water 1998, 36, 545-546. [CrossRef]

525. Burek, P.; Langan, S.; Cosgrove, W.; Fischer, G.; Kahil, T.; Magnuszewski, P.; Satoh, Y.; Tramberend, S.; Wada, Y.; Wiberg, D. The Water Futures and Solutions Initiative of IIASA; International Institute for Applied Systems Analysis (IIASA): Laxenburg, Austria, 2016.

526. Shiklomanov, I.A. Assessment of Water Resources and Water Availability in the World: Scientific and Technical Report; Russian State Hydrological Institute: St. Petersburg, Russia, 1996.

527. Grove, A.T. The geography of semi-arid lands. Phil. Trans. R. Soc. Lond. B 1977, 278, 457-475.

528. Mortimore, M.; Anderson, S.; Cotula, L.; Davies, J.; Faccer, K.; Hesse, C.; Morton, J.; Nyangena, W.; Skinner, J.; Wolfangel, C. Dryland Opportunities: A new paradigm for people, ecosystems and development; IIED: London, UK, 2009.

529. United Nations Environment Management Group. Global Drylands: A UN System-Wide Response; United Nations Environment Management Group: Geneva, Switzerland, 2011.

530. Bychkov, I.; Gagarinova, O.; Orlova, I.; Bogdanov, V. Water Protection Zoning as an Instrument of Preservation for Lake Baikal. Water 2018, 10, 1474. [CrossRef]

531. Afanas'ev, A.N. Vodnye resursy i vodnyi balans basseina oz. Baikal (Water Resources and Water Balance of the Baikal Lake Basin); Nauka: Moscow, Russia, 1976.

532. Fry, A.; Haden, E.; Martin, M.; Fry, A.; Haden, E.; Martin, M. Facts and Trends: Water. World Business Council for Sustainable Development; UN Water: Geneva, Switzerland, 2005.

533. Demin, A.P. Water resources and food program. Water Resour. 2014, 41, 232-241. [CrossRef]

534. UNESCO. Map of the World Distribution of Arid Regions: Explanatory Note; UNESCO: Paris, France, 1979 ; Volume 7.

535. Flint, A.L.; Flint, L.E.; Hevesi, J.A.; Blainey, J.B. Fundamental Concepts of Recharge in the Desert Southwest: A Regional Modeling Perspective. In Groundwater Recharge in a Desert Environment: The Southwestern United States Water Science and Application; American Geophysical Union: Washington, DC, USA, 2004; Volume 9, pp. 159-184.

536. Dynesius, M.; Nilsson, C. Fragmentation and flow regulation of rivers. Sci. New Ser. 1994, 266, 753-762.

537. Postel, P.; Daily, S.L.; Ehrlich, G.C. Human Appropriation of Renewable Fresh Water. Science 1996, 271, 785-788. [CrossRef]

538. Biggs, E.M.; Duncan, J.M.A.; Atkinson, P.M.; Dash, J. Plenty of water, not enough strategy: How inadequate accessibility, poor governance and a volatile government can tip the balance against ensuring water security: The case of Nepal. Environ. Sci. Policy 2013, 33, 388-394. [CrossRef] 
539. Ogino, S.Y.; Yamanaka, M.D.; Mori, S.; Matsumoto, J. How much is the precipitation amount over the tropical coastal region? J. Clim. 2016, 29, 1231-1236. [CrossRef]

540. Curtis, S. Means and Long-Term Trends of Global Coastal Zone Precipitation. Sci. Rep. 2019, 9, 1-9. [CrossRef] [PubMed]

541. Jahfer, S.; Vinayachandran, P.N.; Nanjundiah, R.S. Long-Term impact of Amazon River runoff on northern hemispheric climate. Sci. Rep. 2017, 7, 1-9. [CrossRef] [PubMed]

542. Tyaquiçã, P.; Veleda, D.; Lefèvre, N.; Araujo, M.; Noriega, C.; Caniaux, G.; Servain, J.; Silva, T. Amazon plume salinity response to ocean teleconnections. Front. Mar. Sci. 2017, 4, 1-14. [CrossRef]

543. Lewis, S.L.; Brando, P.M.; Phillips, O.L.; van der Heijden, G.M.F.; Nepstad, D. The 2010 Amazon drought. Science 2011, $331,554$. [CrossRef] [PubMed]

544. Dai, A.; Trenberth, K.E. Estimates of Freshwater Discharge from Continents: Latitudinal and Seasonal Variations. J. Hydrometeorol. 2002, 3, 660-687. [CrossRef]

545. Oki, T.; Kanae, S. Global hydrological cycles and world water resources. Science 2006, 313, 1068-1072. [CrossRef]

546. Dai, A.; Qian, T.; Trenberth, K.E.; Milliman, J.D. Changes in continental freshwater discharge from 1948 to 2004. J. Clim. 2009, 22, 2773-2792. [CrossRef]

547. Shi, X.; Qin, T.; Nie, H.; Weng, B.; He, S. Changes in major global river discharges directed into the ocean. Int. J. Environ. Res. Public Health 2019, 16, 1469. [CrossRef]

548. Peterson, B.J.; Holmes, R.M.; McClelland, J.; Vörösmarty, C.J.; Lammers, R.B.; Shiklomanov, A.I.; Shiklomanov, I.A.; Rahmstorf, S. Increasing river discharge to the Arctic Ocean. Science 2002, 298, 2171-2173. [CrossRef]

549. L'Vovich, M.L.; White, G.F. Use and transformation of terrestrial water systems. In The Earth as Transformed by Human Action; Turner, B.L., II, Clark, W.C., Kates, R.W., Richards, J.F., Mathews, J.T., Meyer, W.B., Eds.; Cambridge University Press: Cambridge, UK, 1990; pp. 235-252.

550. Thober, S.; Kumar, R.; Wanders, N.; Marx, A.; Pan, M.; Rakovec, O.; Samaniego, L.; Sheffield, J.; Wood, E.F.; Zink, M. Multi-model ensemble projections of European river floods and high flows at 1.5, 2, and 3 degrees global warming. Environ. Res. Lett. 2017, 13. [CrossRef]

551. Machado, M.J.; Botero, B.A.; López, J.; Francés, F.; Díez-Herrero, A.; Benito, G. Flood frequency analysis of historical flood data under stationary and non-stationary modelling. Hydrol. Earth Syst. Sci. 2015, 19, 2561-2576. [CrossRef]

552. Odry, J.; Arnaud, P. Comparison of flood frequency analysis methods for ungauged catchments in France. Geoscience 2017, 7, 24. [CrossRef]

553. Madsen, H.; Lawrence, D.; Lang, M.; Martinkova, M.; Kjeldsen, T. WG4: Flood Frequency Estimation Methods and Environmental Change; Centre for Ecology and Hydrology Bailrigg: Lancaster, UK, 2013.

554. Lawrence, D. Uncertainty introduced by flood frequency analysis in projections for changes in flood magnitudes under a future climate in Norway. J. Hydrol. Reg. Stud. 2020, 28, 100675. [CrossRef]

555. Yin, J.; Guo, S.; Gu, L.; He, S.; Ba, H.; Tian, J.; Li, Q.; Chen, J. Projected changes of bivariate flood quantiles and estimation uncertainty based on multi-model ensembles over China. J. Hydrol. 2020, 585. [CrossRef]

556. Hu, L.; Nikolopoulos, E.I.; Marra, F.; Anagnostou, E.N. Sensitivity of flood frequency analysis to data record, statistical model, and parameter estimation methods: An evaluation over the contiguous United States. J. Flood Risk Manag. 2020, 13, 1-13. [CrossRef]

557. Topaloğlu, F. Regional flood frequency analysis of the basins of the East Mediterranean region. Turkish J. Agric. Forestry 2005, 29, 287-295.

558. Yu, X.; Cohn, T.A.; Stedinger, J.R. Flood frequency analysis in the context of climate change. In Proceedings of the World Environment Water Resource Congress 2015, Floods, Droughts, Ecosyst, Austin, TX, USA, 17-21 May 2015; pp. $2376-2385$.

559. Demissie, S.; Cunnane, C. Representation of Climate Change in Flood Frequency Estimation; National University of Ireland: Galway, Ireland, 2002.

560. Maghsood, F.F.; Moradi, H.; Bavani, A.R.M.; Panahi, M.; Berndtsson, R.; Hashemi, H. Climate change impact on flood frequency and source area in northern Iran under CMIP5 scenarios. Water 2019, 11, 273. [CrossRef]

561. Reynard, N.; Crooks, S.; Wilby, R.; Kay, A. Climate change and flood frequency in the UK. In Proceedings of the 39th Defra Flood and Coastal Flood management Conference, York, UK, 29 June-1 July 2004; pp. 1-12.

562. Salles, C.; Chu, Y.; Perrin, J.L.; Tournoud, M.G.; Boudet, L.; Cres, F.N.; Rodier, C.; Zheng, S.; Huang, L.; Ma, Y. Flood duration frequency analysis in a changing climate: The methodology applied to Fengle River (Yangtze basin, China). IAHS-AISH Proc. Rep. 2014, 363, 54-59.

563. Olsson, T.; Jakkila, J.; Veijalainen, N.; Backman, L.; Kaurola, J.; Vehviläinen, B. Impacts of climate change on temperature, precipitation and hydrology in Finland-Studies using bias corrected Regional Climate Model data. Hydrol. Earth Syst. Sci. 2015, 19, 3217-3238. [CrossRef]

564. Morton, J.F. The impact of climate change on smallholder and subsistence agriculture. Proc. Natl. Acad. Sci. USA 2007, 104, 19680-19685. [CrossRef] [PubMed]

565. Muller, C.; Takayabu, Y. Response of precipitation extremes to warming: What have we learned from theory and idealized cloud-resolving simulations, and what remains to be learned? Environ. Res. Lett. 2020, 15. [CrossRef]

566. Li, J.; Wang, M.H.; Ho, Y.S. Trends in research on global climate change: A Science Citation Index Expanded-based analysis. Glob. Planet. Chang. 2011, 77, 13-20. [CrossRef] 
567. Sarhadi, A.; Soulis, E.D. Time-varying extreme rainfall intensity-duration-frequency curves in a changing climate. Geophys. Res. Lett. 2017, 44, 2454-2463. [CrossRef]

568. Liang, S.; Wang, W.; Zhang, D. Characteristics of annual and seasonal precipitation variation in the upstream of Minjiang River, Southwestern China. Adv. Meteorol. 2018, 18,1-15. [CrossRef]

569. Li, W.; He, X.; Scaioni, M.; Yao, D.; Mi, C.; Zhao, J.; Chen, Y.; Zhang, K.; Gao, J.; Li, X. Annual precipitation and daily extreme precipitation distribution: Possible trends from 1960 to 2010 in urban areas of China. Geomatics Nat. Hazards Risk 2019, 10, 1694-1711. [CrossRef]

570. Song, X.; Zhang, J.; Zhang, C.; Zou, X. A Comprehensive Analysis of the Changes in Precipitation Patterns over Beijing during 1960-2012. Adv. Meteorol. 2019, 2019, 1-22. [CrossRef]

571. Zhang, Y.; Liang, C. Analysis of Annual and Seasonal Precipitation Variation in the Qinba Mountain area, China. Sci. Rep. 2020, 10, 1-13. [CrossRef] [PubMed]

572. Tošić, I.; Hrnjak, I.; Gavrilov, M.B.; Unkašević, M.; Marković, S.B.; Lukić, T. Annual and seasonal variability of precipitation in Vojvodina, Serbia. Theor. Appl. Climatol. 2013, 117, 331-341. [CrossRef]

573. Bajat, B.; Pejović, M.; Luković, J.; Manojlović, P.; Ducić, V.; Mustafić, S. Mapping average annual precipitation in Serbia (1961-1990) by using regression kriging. Theor. Appl. Climatol. 2013, 112, 1-13. [CrossRef]

574. Zubovic, J.; Jelocnik, M.; Zdravkovic, A.; Subic, J.; Radovanovic, S. Using Spatial and Seasonal Panel Model to Determine Impact of Climatic Factors on Maize Yields in Serbia. Rom. Biotechnol. Lett. 2018, 23, 13383-13393.

575. Modarres, R.; Sarhadi, A. Rainfall trends analysis of Iran in the last half of the twentieth century. J. Geophys. Res. Atmos. 2009, 114, 1-10. [CrossRef]

576. Khalili, K.; Tahoudi, M.N.; Mirabbasi, R.; Ahmadi, F. Investigation of spatial and temporal variability of precipitation in Iran over the last half century. Stoch. Environ. Res. Risk Assess. 2016, 30, 1205-1221. [CrossRef]

577. Khozeymehnezhad, H.; Tahroudi, M.N. Annual and seasonal distribution pattern of rainfall in Iran and neighboring regions. Arab. J. Geosci. 2019, 12, 271. [CrossRef]

578. Guhathakurta, P.; Rajeevan, M. Trends in the rainfall pattern over India. Int. J. Climatol. 2008, 28, 1453-1469. [CrossRef]

579. Fishman, R. More uneven distributions overturn benefits of higher precipitation for crop yields. Environ. Res. Lett. 2016, 11, 024004. [CrossRef]

580. Rai, P.; Dimri, A.P. Changes in rainfall seasonality pattern over India. Meteorol. Appl. 2020, 27, 1-6. [CrossRef]

581. Nicholson, S.E.; Funk, C.; Fink, A.H. Rainfall over the African continent from the 19th through the 21st century. Glob. Planet. Chang. 2018, 165, 114-127. [CrossRef]

582. Mardero, S.; Schmook, B.; Christman, Z.; Metcalfe, S.E.; de la Barreda-Bautista, B. Recent disruptions in the timing and intensity of precipitation in Calakmul, Mexico. Theor. Appl. Climatol. 2020, 140, 129-144. [CrossRef]

583. Ragno, E.; AghaKouchak, A.; Love, C.A.; Cheng, L.; Vahedifard, F.; Lima, C.H.R. Quantifying Changes in Future IntensityDuration-Frequency Curves Using Multimodel Ensemble Simulations. Water Resour. Res. 2018, 54, 1751-1764. [CrossRef]

584. Government of India; Ministry of Environment and Forests. India Second National Communication to the United Nations Framework Convention on Climate Change; Ministry of Environment and Forests, Government of India: New Delhi, India, 2012.

585. Ghil, M.; Lucarini, V. The physics of climate variability and climate change. Rev. Mod. Phys. 2020, 92, 035002. [CrossRef]

586. Cooke, R.M. Messaging climate change uncertainty. Nat. Clim. Chang. 2015, 5, 8-10. [CrossRef]

587. Nearing, G.S.; Tian, Y.; Gupta, H.V.; Clark, M.P.; Harrison, K.W.; Weijs, S.V. A philosophical basis for hydrological uncertainty. Hydrol. Sci. J. 2016, 61, 1666-1678. [CrossRef]

588. Joseph, J.; Ghosh, S.; Pathak, A.; Sahai, A.K. Hydrologic impacts of climate change: Comparisons between hydrological parameter uncertainty and climate model uncertainty. J. Hydrol. 2018, 566, 1-22. [CrossRef]

589. Dayon, G.; Boé, J.; Martin, É.; Gailhard, J. Impacts of climate change on the hydrological cycle over France and associated uncertainties. Comptes Rendus Geosci. 2018, 350, 141-153. [CrossRef]

590. Kundzewicz, Z.W.; Krysanova, V.; Benestad, R.E.; Hov, Ø.; Piniewski, M.; Otto, I.M. Uncertainty in climate change impacts on water resources. Environ. Sci. Policy 2017, 79, 1-8. [CrossRef]

591. Clark, M.P.; Wilby, R.L.; Gutmann, E.; Vano, J.A.; Gangopadhyay, S.; Wood, A.W.; Fowler, H.J.; Prudhomme, C.; Arnold, J.R.; Brekke, L.D. Characterizing Uncertainty of the Hydrologic Impacts of Climate Change. Curr. Clim. Chang. Rep. 2016, 2, 55-64. [CrossRef]

592. Schmied, H.M.; Adam, L.; Eisner, S.; Fink, G.; Flörke, M.; Kim, H.; Oki, T.; Portmann, F.T.; Reinecke, R.; Riedel, C.; et al. Variations of global and continental water balance components as impacted by climate forcing uncertainty and human water use. Hydrol. Earth Syst. Sci. 2016, 20, 2877-2898. [CrossRef]

593. Thompson, J.R.; Laizé, C.L.R.; Green, A.J.; Acreman, M.C.; Kingston, D.G. Climate change uncertainty in environmental flows for the Mekong River. Hydrol. Sci. J. 2014, 59, 935-954. [CrossRef]

594. Hoffman, F.O.; Hammonds, J.S. Propagation of uncertainty in risk assessments: The need to distinguish between uncertainty due to lack of knowledge and uncertainty due to variabi. Risk Anal. 1994, 14, 707-712. [CrossRef] [PubMed]

595. Fletcher, S.; Lickley, M.; Strzepek, K. Learning about climate change uncertainty enables flexible water infrastructure planning. Nat. Commun. 2019, 10,1-11. [CrossRef]

596. Stakhiv, E.Z. Policy implications of climate change impacts on water resources management. Water Policy 1998, 1, 159-175. [CrossRef] 
597. Haasnoot, M.; Kwakkel, J.H.; Walker, W.E.; Maat, J.T. Dynamic adaptive policy pathways: A method for crafting robust decisions for a deeply uncertain world. Glob. Environ. Chang. 2013, 23, 485-498. [CrossRef]

598. Farmer, W.H.; Vogel, R.M. On the deterministic and stochastic use of hydrologic models. Water Resour. Res. 2016, 52, 5619-5633. [CrossRef]

599. Tase, N. Area-Deficit-Intensity Characteristics of Droughts; Colorado State University: Fort Collins, CO, USA, 1976 ; Volume 87.

600. Yevjevich, V. Structural Analysis of Hydrologic Time Series; Colorado State University: Fort Collins, CO, USA, $1972 ;$ p. 56.

601. Petelczyc, M.; Gac, J.M. Separation of deterministic and stochastic components from time series. Acta Phys. Pol. B, Proc. Suppl. 2014, 7, 395-405. [CrossRef]

602. Fatichi, S.; Barbosa, S.M.; Caporali, E.; Silva, M.E. Deterministic versus stochastic trends: Detection and challenges. J. Geophys. Res. Atmos. 2009, 114, 1-11. [CrossRef]

603. Ha-Duong, M. Review of Risk and Uncertainty Concepts for Climate Change Assessments Including Human Dimensions; CIRED-Centre international de recherche sur l'environnement et le développement: Nogent-sur-Marne, France, 2012.

604. Chen, Y.; Fanke, M.; Glanemann, N. Knightian Uncertainty and Climate Change; CESifo: Munich, Germany, 2011.

605. Smith, L.A.; Stern, N. Uncertainty in science and its role in climate policy. Phil. Trans. R. Soc. A 2011, 369. [CrossRef]

606. Knight, F.H. Risk, Uncertainty, and Profit; Liberty Fund, Inc.: Indianapolis, IN, USA, 1921.

607. Baumgärtner, S.; Engler, J.-O. An axiomatic foundation of entropic preferences under Knightian uncertainty. In Beiträge zur Jahrestagung des Vereins für Socialpolitik 2018: Digitale Wirtschaft-Session: Theory-Concepts; Informationszentrum Wirtschaft: Kiel, Germany, 2018; p. 57.

608. Mittelstaedt, C.; Baumgärtner, S. Preference Functions for Knightian Uncertainty Zurich; ETH: Zurich, Switzerland, 2020.

609. Georgescu-Roegen, N. The Entropy Law and the Economic Process in Retrospect. East. Econ. J. 1986, 12, 3-25.

610. Faber, M.; Frick, M.; Zahrnt, D. Absolute and Relative Scarcity MINE Website. 2019. Available online: www.nature-economy.com (accessed on 22 February 2021).

611. Dooge, J.C.I. The hydrologic cycle as a closed system. Int. Assoc. Sci. Hydrol. Bull. 1968, 13, 58-68. [CrossRef]

612. Konings, A.G.; Feng, X.; Molini, A.; Manzoni, S.; Vico, G.; Porporato, A. Thermodynamics of an idealized hydrologic cycle. Water Resour. Res. 2012, 48. [CrossRef]

613. Gleeson, T.; Wang-Erlandsson, L.; Zipper, S.C.; Porkka, M.; Jaramillo, F.; Gerten, D.; Fetzer, I.; Cornell, S.E.; Piemontese, L.; Gordon, L.J.; et al. The Water Planetary Boundary: Interrogation and Revision. One Earth 2020, 2, 223-234. [CrossRef]

614. United Nations. Concise Report on the World Population Situation in 2014; United Nations: New York, NY, USA, 2014.

615. Our World in Data, Renewable Freshwater Resources. Our World in Data. 2021. Available online: https://ourworldindata.org/ grapher/internal-renewable-freshwater-resources-by-region (accessed on 21 May 2021).

616. Faber, M.; Manstetten, R.; Müller, G. Interdisziplinäre Umweltforschung aus ökonomischer Sicht. Naturwissenschaften 1994, 81, 193-199. [CrossRef]

617. Baumgärtner, S.; Becker, C.; Faber, M.; Manstetten, R. Relative and absolute scarcity of nature. Assessing the roles of economics and ecology for biodiversity conservation. Ecol. Econ. 2006, 59, 487-498. [CrossRef]

618. Hummel, S. Relative water scarcity and country relations along cross-boundary rivers: Evidence from the Aral Sea basin. Int. Stud. Q. 2017, 61, 795-808. [CrossRef]

619. Yoffe, S.; Wolf, A.T.; Giordano, M. Conflict and cooperation over international freshwater resources: Indicators of basins at risk. J. Am. Water Resour. Assoc. 2003, 39, 1109-1126. [CrossRef]

620. Akamani, K.; Wilson, P.I. Toward the adaptive governance of transboundary water resources. Conserv. Lett. 2011, 4, 409-416. [CrossRef]

621. Armitage, D.; De Loë, R.C.; Morris, M.; Edwards, T.W.D.; Gerlak, A.K.; Hall, R.I.; Huitema, D.; Ison, R.; Livingstone, D.; Macdonald, G.; et al. Science-policy processes for transboundary water governance. Ambio 2015, 44, 353-366. [CrossRef] [PubMed]

622. Poynder, J. Literary Extracts from English and other Works; John Hatchard \& Son: London, UK, $1844 ;$ Volume 1.

623. Dolan, F.; Lamontagne, J.; Link, R.; Hejazi, M.; Reed, P.; Edmonds, J. Evaluating the economic impact of water scarcity in a changing world. Nat. Commun. 2021, 12,1-10. [CrossRef] [PubMed]

624. Hernandez, Y.; Naumann, G.; Corral, S.; Barbosa, P. Water footprint expands with gross domestic product. Sustainability 2020, 12, 8741. [CrossRef]

625. Aqueduct, Aqueduct Country Rankings Aqueduct. 2019. Available online: https://www.wri.org/applications/aqueduct/ country-rankings/ (accessed on 22 April 2021).

626. Amjath-Babu, T.; Bhaskar, P.; Aggarwal, P. Do Virtual Water Transfers Act as an Adaptation Mechanism to Droughts? A Global Analysis; FAO: Rome, Italy, 2016.

627. Hoekstra, A.Y. The Relation between International Trade and Freshwater Scarcity; Working Paper; World Trade Organization Economic Research and Statistics Division: Geneva, Switzerland, 2010.

628. Roson, R.; Sartori, M. Water Scarcity and Virtual Water Trade in the Mediterranean; IEFE The Center for Research on Energy and Environmental Economics and Policy at Bocconi University Milano: Milano, Italy, 2010.

629. Novo, P.; Garrido, A.; Varela-Ortega, C. Are virtual water 'flows' in Spanish grain trade consistent with relative water scarcity? Ecol. Econ. 2009, 68, 1454-1464. [CrossRef] 
630. Carrión, J.; Fernández, S.; Jiménez-Moreno, G.; Fauquette, S.; Gil-Romera, G.; González-Sampériz, P.; Finlayson, C. The historical origins of aridity and vegetation degradation in southeastern Spain. J. Arid Environ. 2010, 74, 731-736. [CrossRef]

631. Tejedor, E.; de Luis, M.; Cuadrat, J.M.; Esper, J.; Saz, M.Á. Tree-ring-based drought reconstruction in the Iberian Range (east of Spain) since 1694. Int. J. Biometeorol. 2016, 60, 361-372. [CrossRef] [PubMed]

632. D’Odorico, P.; Carr, J.; Dalin, C.; Dell'Angelo, J.; Konar, M.; Laio, F.; Ridolfi, L.; Rosa, L.; Suweis, S.; Tamea, S.; et al. Global virtual water trade and the hydrological cycle: Patterns, drivers, and socio-environmental impacts Global virtual water trade and the hydrological cycle: Patterns, drivers, and socio-environmental impacts. Environ. Res. Lett. 2019, 14, 053001. [CrossRef] 